
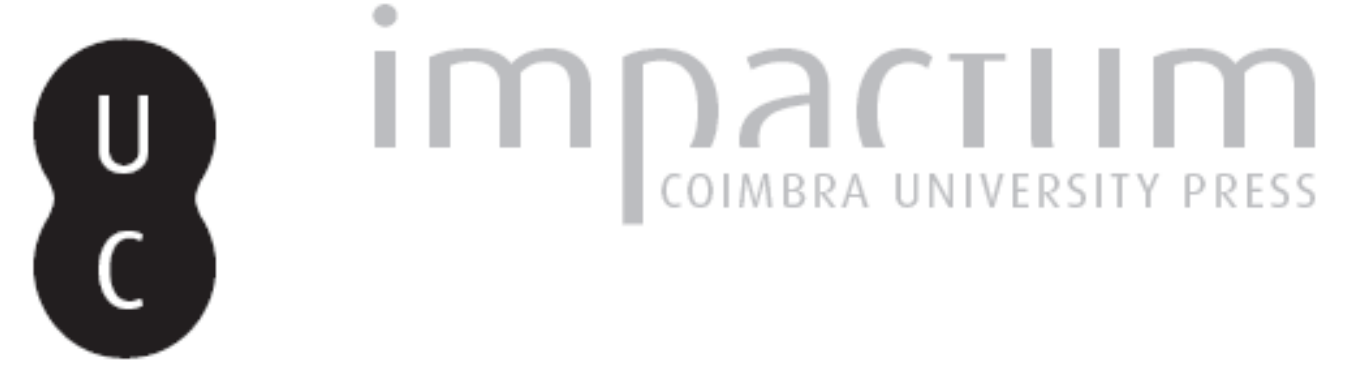

\title{
António Sérgio tradutor: a tradução das «Meditationes/Meditations» de Descartes (1930): primeira aproximação: paleografia e lexicografia
}

\author{
Autor(es): $\quad$ Veloso, Aurélio Menezes \\ Publicado por: Imprensa da Universidade de Coimbra \\ URL \\ persistente: \\ URI:http://hdl.handle.net/10316.2/45045 \\ DOI: \\ DOI:https://doi.org/10.14195/2183-8925_5-1_6
}

Accessed : $\quad$ 26-Apr-2023 10:35:18

A navegação consulta e descarregamento dos títulos inseridos nas Bibliotecas Digitais UC Digitalis, UC Pombalina e UC Impactum, pressupõem a aceitação plena e sem reservas dos Termos e Condições de Uso destas Bibliotecas Digitais, disponíveis em https://digitalis.uc.pt/pt-pt/termos.

Conforme exposto nos referidos Termos e Condições de Uso, o descarregamento de títulos de acesso restrito requer uma licença válida de autorização devendo o utilizador aceder ao(s) documento(s) a partir de um endereço de IP da instituição detentora da supramencionada licença.

Ao utilizador é apenas permitido o descarregamento para uso pessoal, pelo que o emprego do(s) título(s) descarregado(s) para outro fim, designadamente comercial, carece de autorização do respetivo autor ou editor da obra.

Na medida em que todas as obras da UC Digitalis se encontram protegidas pelo Código do Direito de Autor e Direitos Conexos e demais legislação aplicável, toda a cópia, parcial ou total, deste documento, nos casos em que é legalmente admitida, deverá conter ou fazer-se acompanhar por este aviso.

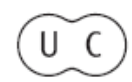




\section{REVISTA DE HISTÓRIA DAS IDEIAS 5}

\section{António Sérgio}

*

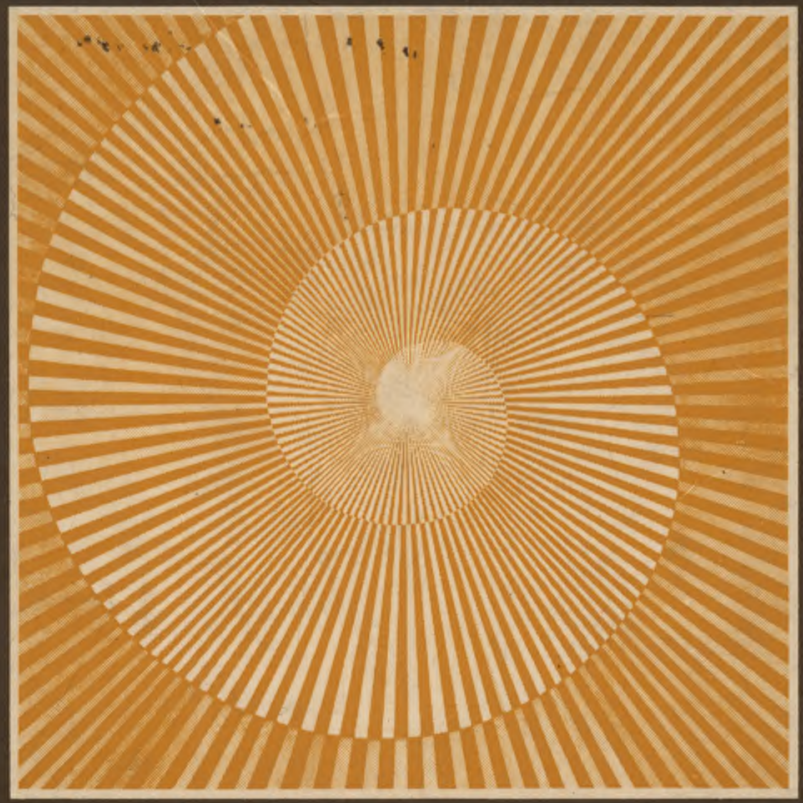

INSTITUTO DE HISTÓRIA E TEORIA DAS IDEIAS FACULDADE DE LETRAS 


\title{
ANTÓNIO SÉRGIO TRADUTOR
}

\author{
A tradução das \\ de Descartes (1930). \\ Primeira aproximação: paleografia e lexicografia.
}

\begin{abstract}
Nous ne connaissons les choses que par les systèmes de transformation des ensembles qui les comprennent. Au minimum, ces systèmes sont quatre. La déduction, dans l'aire logico-mathématique. L'induction, dans le champ expérimental. La production, dans les domaines de pratique. La traduction dans l'espace des textes $C$ ).
\end{abstract}

Autor multimoda ( ${ }^{2}$ ), Antonio Sérgio desenvolveu a sua actividade por considerável número de domínios. A bibliografia agora publicada na sua versão mais exaustiva $\left(^{(3}\right)$, é prova cabal do que afirmamos.

Porém, se muitos desses domínios têm sido objecto de importantes estudos, não é do nosso conhecimento que até ao presente momento algum estudo tenha perspectivado A. Sérgio como tradutor. Todavia parece-nos tratar-se de um aspecto particularmente importante. Importância que reside não só nos aspectos inerentes à tradução mas, e igualmente, naqueles concernentes às articulações da própria tradução com os domínios que A. Sérgio tematizou explicitamente nas suas obras, tais os da pedagogia, da história, da filosofia, da sociologia e da política.

Uma rápida consulta da Bibliografia do autor permite duas constatações globais: na primeira, a traduçã̃o aparece como domínio

* Faculdade de Letras da Universidade de Coimbra. de Minuit, 1974, p. 9.

C) Michel Serres, La traduction, Hermès III, Paris, Éditions

C) Ptenato Descartes, Meditações metafísicas, traduzidas por António Sérgio, Coimbra, Imprensa da Universidade, 1930, p. 136. Esta edição passará a ser designada por S., seguido do número da página e da linha.

(3) A. Campos Matos, Bibliografia de A. Sérgio. 
impensado comparada por exemplo, com a pedagogia, a sociologia ou os aspectos políticos destes temas paradigmáticos com os quais se articula. Com efeito, além das poucas linhas que, em alguns prefácios, notas do tradutor e na correspondência com Joaquim de Carvalho $\left({ }^{4}\right)$, tratam muito superficialmente alguns problemas relativos à tradução, não é do nosso conhecimento que A. Sérgio tenha consagrado estudo algum às articulações existentes entre pensamento e linguagem, entre história das ideias e história da língua. A segunda incide sobre o número considerável de obras traduzidas pelo autor. Independentemente de qualquer consideração sobre a generalidade das categorias que utilizamos, podemos distribuir as dezasseis traduções. que a bibliografia, acima referida aponta, em dois grupos - o das traduções de obras literárias e o de traduções de obras filosóficas. No primeiro dos grupos contamos as traduções de $A$ vida em flor de Anatole France (5), Retratos de mulheres de Sainte-Beuve ( ${ }^{6}$ ), Homens e bichos de Axel Munthe ( ${ }^{7}$ ), Lobos do mar de Rudyard Kipling $\left({ }^{8}\right)$, uma série de quatro álbuns dedicados respectivamente às Galerias de pintura dos Museus Alemães, Museu do Louvre, Países Baixos e à Pintura Moderna ( ${ }^{\mathbf{9}}$ ), e finalmente duas obras de Tolstoi: Khadji Murat, o diabo branco e o demónio branco $\left({ }^{\mathbf{1 0}}\right)$. Como traduções de obras filosóficas temos: as Meditações Metafísicas de Descartes, as Últimas conversaçôes de Renouvier $\mathbf{O}^{1}$ ), o preâmbulo e o primeiro livro dos Novos ensaios sobre o entendimento humano, de Leibniz ( ${ }^{12}$ ), a Introdução ao estudo da filosofia de Mc Taggart $\left(^{13}\right.$ ), Os problemas da filosofia de Russell $\left({ }^{14}\right)$, alguns excertos do Emílio de J.-J. Rousseau $\left({ }^{15}\right)$, a Introdução à ciência de Thomson $\left({ }^{16}\right)$, uma

(4) Agradecemos vivamente a gentileza que o dr. Fernando Catroga manifestou ao proporcionar-nos a consulta dos documentos inéditos relativos à correspondência de António Sérgio com Joaquim de Carvalho. Essas peças serão publicadas pela Revista de Historia das Ideias, sob o título «António Sérgio no exílio, cartas a Joaquim de Carvalho", cartas que a partir de agora designaremos por: Correspondência. 345 p.

C) Paris, Casa Editorial Franco-Ibero-Americana, s. d. (1928),

C) Coimbra, Imprensa da Universidade, 1932, 86 p. (1937?), 253 p.

(7) Tradução e prefácio, Lisboa, Editorial Progresso, s. d.

()$\left.^{8}\right)$ Lisboa, Editorial Progresso, s. d. (1937?), 253 p.

(9) Barcelona, Editorial Labor, s. d. (1938?), 4 vols.

$\left(^{10}\right)$ Respectivamente: Tradução indirecta c/ prefácio. Rio de Janeiro, Civilização Brasileira, 1934, 193 p., e: Tradução indirecta c/ prefácio. Lisboa, Editora Arcádia, s. d. (1958?) col. Autores Estrangeiros, $161 \mathrm{p}$.

$\left({ }^{\mathrm{M}}\right)$ Coimbra, Imprensa da Universidade, 1930, 106p.

(12) Coimbra, Imprensa da Universidade, 1931, 155p.

(13) Tradução e prefácio. Lisboa, Editorial Inquérito, 1939'. 216 p. $\left(1941^{2}\right)$.

(14) Tradução e prefácio. Coimbra, Arménio Amado, 1936',

$\left({ }^{16}\right)$ Excertos seleccionados, traduzidos, anotados e prefaciados. Lisboa, Editorial Inquérito, 1940, 2 vols. 237 p.

$\left.{ }^{16}\right)$ Tradução e nota final, Coimbra, Arménio Amado, 1941, 
selecção dos Pensamentos de Marco Aurélio $\left({ }^{\mathbf{1 T}}\right)$, e os Três diálogos

entre Hilas e Filonous em oposição aos cépticos e ateus de Berkeley $\left({ }^{18}\right)$.

Pelo simples facto destes importantes trabalhos se prolongarem, sensivelmente por trinta anos da vida de A. Sérgio (1928-1958?), a interrogação que tentamos colocar aparece-nos suficientemente justificada. Todavia, a resposta a uma tal questão aparece-nos mais como o resultado de um trabalho interdisciplinar, que mobiliza competências de horizontes diversos, e não como o resultado de uma investigação pessoal que excede largamente as nossas possibilidades. Portanto, além de colocar a questão, - e no vivo desejo de a ver futuramente retomada pelos estudiosos da obra de A. Sérgio - escolhemos tratar alguns dos pontos de uma das suas componentes; a tradução das Meditações de Descartes.

Pareceu-nos importante considerar detalhadamente tal tradução, dado que, não só o texto traduzido é um texto capital do pensamento ocidental, mas também porque a sua paleografia e a sua história são complexas. Para melhor poder determinar as opções do tradutor, optamos por uma ressituação histórica das três edições que apareceram durante a vida de Descartes, e pela enumeração dos titulos e das peças constitutivas dessas edições. Após uma recensão das homologias e das divergências existentes entre essas edições, julgamos importante referir rapidamente as caracteristicas das três grandes edições que a obra conheceu entre a morte do autor e o momento da tradução portuguesa: tais referências, não só nos permitem apreciar o sentido global das preocupações dos sucessivos editores da obra, mas também, situar o tradutor relativamente a tais tendências. A descrição sumária de três das edições mais importantes dessa obra posteriores a 1930, permite-nos melhor delinear o perfil da tradução portuguesa que estudamos. Os diagramas das fontes utilizadas pelas edições referidas completam esta parte do nosso estudo.

Submetemos em seguida a tradução portuguesa a uma série de comparações que têm como referente a edição francesa de 1647. Fundamentalmente estas comparações visam detectar as variações de signos, de regras, (ortografia, pontuação, travessões, itálicos, aspas e parênteses) e do léxico.

Se relativamente ao léxico latino e francês de Descartes, estamos actualmente bem informados, a inexistência de um Thesaurus da língua portuguesa do séc. XVII, compromete à partida o rigor do nosso estudo. Por outro lado, dado que uma análise exaustiva das variações lexicais na tradução portuguesa é uma tarefa materialmente impossível no quadro da metodologia de que dispomos, optamos por sondar a tradução portuguesa a partir de dois termos de significação sobredeterminada na obra de Descartes (e de um modo geral na metafísica): RAISON (e o seu plural) e NATURE. Essas análises revelaram-nos para além das concordâncias, conjuntos apreciáveis de omissões, adições e vicariâncias, que um grupo de seis gráficos sintetiza.

75 p.

(") Selecção, tradução e prefácio. Lisboa, Edições Ática, 1947,

(i») Tradução, prefácio e notas. Coimbra, Atlântida Editora,
$1948^{1} 185$ p. $\left(1^{2} 5^{2}\right)$. 
Porque uma abertura de perspectivas não concerne uma conclusão, terminaremos por uma rápida enumeração das preocupações expressas por A. Sérgio na sua Nota do Tradutor, preocupações essas que a sua correspondência com Joaquim de Carvalho confírma e amplifica C).

\section{I}

1.1.Se o título da primeira edição tem algo em comum com as obras da época quando anuncia a demonstração da existência de Deus e da imortalidade da alma, pelo próprio facto de propor a demonstração como modalidade priveligiada da prova $\left({ }^{20}\right)$, ele marca a distância irredutível que separa a metodologia do autor da utilizada em obras que na mesma época tratam os mesmos temas $\left({ }^{21}\right)$.

Duas peças da correspondência trocada com Mersenne em 1630, revelam-se particularmente elucidativas quanto aos projectos do autor: numa dessas cartas ele anuncia «un petit Traité de Métaphysique, e acrescenta que, les principaux points sont de prouver l'existence de Dieu, et celle de nos âmes, lorsqu'elles sont séparées du corps, d'où suit leur immortalité»» $\left.{ }^{22}\right)$; na outra, quando Descartes escreve a propósito do

$\left({ }^{10}\right)$ As edições de obras de Descartes utilizadas são as seguintes:

a) Oeuvres de Descartes, publiées par Charles Adam et Paul Tannery, 11 tomes in-4, Paris, Leopold Cerf, 1897-1909. O t. XII desta edição é constituído por uma Vie et oeuvre de Descartes par Charles Adam. Esta edição foi reeditada na livraria J. Vrin - C.N.R.S. 1964-1974 .

Nas nossas citações esta edição é designada pelas siglas A.T., seguidas do número do tomo em números romanos, do número de página em números árabes e por vezes da linha.

b) Meditationes de prima philosophia. Meditations Métaphysiques. Texte latin et traduction du duc de Luynes. Introduction et notes par Geneviève Rodis-Lewis, Paris, J. Vrin, 1978. Esta obra é citada: G. R-L., M. M, seguido do número da página.

c) Oeuvres philosophiques, publiées par Ferdinand Alquié, 3 tomes, Paris, Garnier Frères, 1963, 1967, 1973. Esta obra é citada: Alq., seguido do número do tomo em caracteres romanos e do número da página em caracteres árabes.

Subsidiariamente utilizamos: d) Descartes, Oeuvres et lettres, textes présentés par André Bridoux, Paris, Bibliothèque de la Pléiade, Gallimard - N.R.F., 1953; e) Discours de la méthode, suivi des Méditations, présentation et annotation par François Misrachi, Paris, Union Générale d'Editions, 1951, 313 p. Dada a amplitude dos estudos cartesianos, será sempre útil consultar: Gregor Sebba, Bibliografia cartesiana, (1800-1960), The Hague, Martinus Nijhoff. 1964, XV, 510 p.

(20) Sobre o poder persuasivo das demonstrações, cf. a Mersenne, 25 avril, 1630, A.T. I. 181-182.

$\left.{ }^{21}\right)$ Cf. Geneviève Rodis-Lewis, M.M. pp. VI-VII, m.

${ }^{22}$ A Mersenne, 25 novembre 1630, A.T. I. 182. 
método: «Au moins pense-je avoir trouvé comment on peut démontrer les vérités métaphysiques dune façon qui est plus évidente que les démonstrations de géométrie» $\left({ }^{23}\right)$.

Estes extractos permitem-nos concluir, que a obra que Descartes projecta desde 1630 não é nem um tratado apologético, nem um tratado de teologia, mas sim uma obra de carácter filosófico, estabelecida segundo um modelo geométrico, - de inspiração euclidiana -, considerado pelo autor como o paradigma da disposição arquitectónica do conceito.

Tais intenções encontram-se pontualmente confirmadas ao longo da década que separa estas cartas e a publicação da obra. Assim, em 1638, o projecto continuava centrado e tematizado em torno de razão: Descartes anuncia a Mersenne querer «éclaircir les raisons.... de l'existence de Dieu, e acrescenta um elemento que decididamente diferencia a obra em elaboração da publicada em 1637, quando escreve: mais, j'en écrirai en latin» $\left({ }^{24}\right)$. Decididamente, a quarta parte do Discurso do método, - que a primeira página da obra anuncia como destinada a provar «l'existence de Dieu et de l'âme humaine qui sont les fondements de la métaphysique» $\left({ }^{25}\right)-$, não satisfez o autor. Tal descontentamento advém não só de incidentes inerentes à edição, mas, e sobretudo, «la principale raison de son obscurité vient de ce que je n'ai pas osé m'étendre sur les raisons des sceptiques» $\left({ }^{26}\right)$. Em 1639, ano em que Descartes continua ainda a preocupar-se com os ecos das polémicas desencadeadas pelos Ensaios científicos de 1637, uma nova carta dirigida a Mersenne precisa que a obra em preparação "contiendra une bonne partie de la Métaphysique» $\left({ }^{27}\right)$.

Tal obra, cu ja redacção terminou na Primavera de $1640\left({ }^{28}\right)$, foi enfim enviada a Mersenne, pelo intermédio de Huygens, em 11 de Novembro de 1640. Antes de fazer este envio, Descartes tinha feito verificar e corrigir a pontuação

\footnotetext{
$\left.{ }^{23}\right)$ A Mersenne, 15 avril 1630, A.T. I. 144.

C) $A$ Mersenne, 27 juillet, 1638, A.T. II. 267.

C) A.T. VI. 1

C $^{26}$ ) A Vatier, 22 février, 1638, A.T. I. 560.

(27) A.T. II. 622.
}

(25) Adrien Baillet, La Vie de Monsieur Descartes, 2 t. Paris, chez Daniel Horthemels, 1691. A partir de agora citado Baillet, V.D., seguido do tomo e número da página.

Segundo Baillet, V.D. II. 103, desde o mês de Maio, Descartes «avait fait voir son manuscrit à quelques amis d'Utrecht qu'il en avait instamment solicité, et particulièrement à Mr. Regius et Aemelius qui en furent charmés jusqu'à l'extase». Segundo F. Alquié, a redacção teria terminado em Abril, cf. Alquié II. 171. 
e a ortografia por Regius e Aemilius, professores da Universidade de Utrecht $\left({ }^{29}\right)$.

$\mathrm{Na}$ carta que confirma o envio da obra a Mersenne, o autor propõe o seguinte título: Renati Descartes $\left.{ }^{(30}\right)$ Meditationes de prima Philosophiae, e justifica-o acrescentando: «car je $n$ y traite pas seulement de Dieu et de l'âme, mais en général de toutes les premières choses que Ton peut connaitre en philosophant», - par ordre-, segundo certos editores.... $\left.{ }^{(31}\right)$.

Ordem, precisamente um dos conceitos capitais do séc. XVII, imperativo que quando conjugado com razão determina as disposições arquitectónicas e estruturais da fina distribuição do conceito e da letra nas Meditações de Descartes $\left({ }^{32}\right)$.

Quando um título definitivo foi adoptado, Mersenne foi o primeiro a notar que a segunda demonstração anuncia$\mathrm{da},-$ - certamente aquela que ele mais esperava $\left({ }^{33}\right)-$, não tinha sido produzida. Respondendo a tal chamada de atenção, Descartes reconhece o facto, mas o título não será modificado enquanto a Sorbonne não aprovar a obra $\left({ }^{34}\right)$.

O título adoptado para a edição de 1641, apresenta portanto os inconvenientes de anunciar matérias não tratadas e de dissimular os objectivos do seu auton mais precisamente, as suas intenções de fundamentar a Física $\left(^{35}\right)$. Todavia, para

O Cf. A.T. XII. 289. Sobre a ortografia de Descartes cf. A.T. I. pp. LXXIX - CV. A carta a Regius de 24 mai 1640 confirma tal correcção, cf. Alq. II. 243-246, (tr. de um anónimo revista por Alquié).

(30) Descartes chegou a pensar imprimir Cartesius, A.T. III. 277.

( ${ }^{31)}$ Alq. II. 277 suprime "par ordre». A.T. III. 239 e G.R.-L, M.M., p. IX mantêm essa expressão.

$\left.{ }^{32}\right)$ De notar uma obra que incide particularmente sobre estas questões: Martial Gueroult, Descartes selon Vordre des raisons, Paris, Aubier Montaigne, 1953, 2 vols.

(M) Notemos que tal como em outras das suas obras, Mersenne consagrou em 1625, alguns argumentos a tal questão: cf. La Vérité dans les sciences. Contre les sceptiques ou pyrrhoniens, Paris, chez Toussainet du Bray, M. DC. XXV, reprodução anastática, Stuttgart — Bad Cannstatt 1969, Friedrich Frommann Verlag (Günther Holzboog), 1008 p.

${ }^{\left({ }^{34}\right)}$ Carta a Mersenne, 24 décembre 1640, A.T. III. 265-266. Sobre a mesma questão, cartas de 11 e 12 novembre 1640, A.T. III. 2351. 10-13 e A.T. III. 241-242. Adam comenta este ponto em, A.T. XII. 293 e 303.

$\mathrm{C}^{35}$ ) Desde o seu estado de projecto, as Meditaçôes estão ligadas com a actividade científica de Descartes, cf. a Mersenne, 15 avril, 1630. As Meditações abrem com esse tema. Na correspondência com Mersenne o mesmo tema aparece constantemente, cf. a Mersenne, 11 novembre, 1940, A.T. III. 233,1. 24-26; e ao mesmo, 28 janvier, 1941, A.T. III. 297, 1. 30-298, 1. 7. Todavia não devemos esquecer os passos onde Descartes aconselha o jovem Burman a não se dedicar demasiado à metafísica. A Elisabeth, ele confessará ainda ter-se dedicado pouco à metafísica, cf. 28 juin, 1943, A.T. III. 692. 1. 25, 693. 1. 05, 695, 1. 04-25. 
um leitor atento à paleografia e à distribuição estrutural dos títulos, uma leitura sinóptica desta obra revela um tremido da letra que na sua conjugação com as disposições retórico-estruturais anunciam uma revolução ${ }^{36}$ ). Com efeito, essas variações de letra, marcam em relação aos títulos primitivos uma involução que não pode deixar de se repercutir no movimento interno das ideias do autor. Assim, ao título da meditação segunda, De naturâ mentis humanae $\left({ }^{37}\right)$, Descartes acrescenta quod ipsa sit notis quàm corpus $\left({ }^{38}\right)$, ao título da meditação terceira, inicialmente designada por De Deo, ele acrescenta: quod existât ${ }^{\left({ }^{39}\right)}$, ao título inicial da meditação quinta, De essentia rerum materialium $\left({ }^{40}\right)$, acrescenta et iterum de Deo, quod existât $\left({ }^{41}\right)$; e por fim, ao título da meditação sexta, De rerum materialim existentiâ $\left({ }^{42}\right)$, acrescenta, et reali mentis à corpore distinctione $\left({ }^{43}\right)$.

Notemos portanto, que mesmo se Descartes solicita Mersenne não só para as correcções ortográficas $\left({ }^{44}\right)$, mas também para modificar os títulos, deixando-lhe «la puissance de baptiser» $\left({ }^{45}\right)$, ele não deixa por isso de estar atento e de atribuir grande importância aos títulos. Se atendermos igualmente à disposição estrutural desses títulos, notaremos que ao anunciar Deus na meditação terceira, somente após ter estabelecido na meditação segunda que o Ego sum, ego existo $\left({ }^{46}\right)$, é a primeira verdade indubitável, Descartes opera uma inversão em relação às disposições do saber escolastico $\left({ }^{47}\right)$, o qual por múltiplas vias e diferentes articulações estabelece em Deus uma anterioridade absoluta de ordem transcendente relativamente às criaturas (homens e coisas). De notar ainda, que tal como a referência a Deus que reaparece na meditação quinta, a referência à alma feita na segunda meditação reaparece na sexta.

A atenção às disposições arquitectónicas da obra expressa nos títulos das suas diferentes partes permite ainda

(38) $\mathbf{T}_{\text {ermo }} \mathbf{q}_{\mathrm{UG}}$ tal como o de sistema, tem no séc. XVII um campo semântico fundamentalmente ligado à astronomia.

$\left.{ }^{37}\right)$ «La nature de l'esprit humain»

${ }^{38}$ «Qu'il est plus aisé à connaître que le corps».

$\left({ }^{3 f 1}\right)$ «Qu'il existe».

( $\left.{ }^{40}\right)$ «De l'essence des choses matérielles».

$\left({ }^{41}\right)$ «Et derechef de l'existence de Dieu».

(42) «De l'existence des choses matérielles».

l'homme».

$\left.i^{43}\right)$ «Et de la distinction réelle entre l'âme et le corps de

$D$ A.T. III. 239, 359, etc...

$\left.{ }^{45}\right)$ A.T. III. 340.

C) A.T. VII. 25, 1. 12; A.T. IX. 19.

$\left({ }^{4}\right)$ Trata-se de um dos aspectos mais marcantes da obra. 
notar a recuperação do mundo operada pela meditação sexta. Tal recuperação abrindo a possibilidade de domínio do mundo físico, reduzido à sua essência geométrica, tornado portanto, terreno privilegiado do desenvolvimento do mecanismo cartesiano, aparece como o contraponto estrutural da dúvida expressa na primeira meditação. Tal articulação, deixa ver claramente as intenções do seu autor ao publicar a sua obra.

É ainda importante notar, que as modificações dos subtítulos acima indicadas, modifícações essas de carácter acentuadamente ontológico, tiveram lugar num momento em que Descartes já tinha recebido as objecções de Carterus $\left({ }^{48}\right)$, tomista ortodoxo, autor das primeiras objecções, objecções essas que já acompanhavam o manuscrito enviado a Mersenne. Foi Mersenne que se encarregou de enviar os manuscritos a Hobbes e aos restantes objectores $\left({ }^{49}\right)$. Esses objectores são o próprio Mersenne e Hobbes $\left({ }^{50}\right)$, autores das segundas e terceiras objecções, Antoine Arnauld, Pierre Gassendi, um grupo de filósofos, geometras e teólogos do círculo de Mersenne, respectivamente autores das quartas, quintas e sextas objecções $\left({ }^{51}\right)$. O editor foi escolhido por Mersenne e o privilégio do rei, o mesmo do Discurso do método, foi transferido para esse editor em 21 de Agosto de $1641\left({ }^{52}\right)$.

título:

1.2. A primeira edição latina apareceu com o seguinte

Renati | DES-CARTES [ MEDITATIONES | DE PRIMA [ I PHILOSOPHIA, I in qua Dei existentia | et Animae immortalitas I demonstratur. | Paris, Michel Soly, M.DC. XLI.

$\left({ }^{48}\right)$ É a vontade de não ser julgado sumariamente pelos seus leitores e pelos poderes, que conduz Descartes à ideia de incorporar na sua obra várias objecções e respostas. Diga-se que após a publicação do Discurso, $o$ clima intelectual não the era o mais favorável: Bourdin,- - autor das sétimas objecções-, tinha defendido em 1639, uma tese na qual atacava vivamente as posições de Descartes. É assim que ele se decide a apresentar a obra «à des personnes capables et de grande réputation pour la Métaphysique, qui prennent la peine d'examiner curieusement mes raisons, et qui, disant franchement ce qu'ils en pensent, donnent par ce moyen le branle aux autres pour en juger comme eux, ou du moins pour avoir honte de leur contredire sans raison» (A.T. III. 102-103).

(48) 0 A $\wedge$ rp 2QJ $3 Q_{2}$

(G0) Carta a Mersenne, 28 janvier, 1941, A.T. III 297.1. 20-30.

O Mersenne envia a Descartes, em 3 de Janeiro de 1641 as objecções que chegam à Holanda em 14 de Janeiro, cf. A.T. XII, 295.

(“) Privilégio reproduzido in A.T. VII. 448. 
E a página de título acrescenta: Cum Privilegio, \& Approbatione Doctorum.

\subsection{Esta edição contém as seguintes peças $\left({ }^{53}\right)$ :}

a) Index; b) carta ao decano e doutores da Faculdade de Teologia de Paris; c) prefácio ao leitor; d) sinopse das seis meditações; e) nova página de título (completo), e nessa mesma página, após a menção PRIMA, segue-se o título e o texto da primeira meditação. As restantes meditaccões sucedem-se segundo a mesma disposição tipográfica; f) na página imediatamente a seguir ao final da sexta meditação começam as seis objecções e respostas; g) segue-se um extracto do privilégio do rei; $h$ ) e na página final, uma errata.

2.1. Desde os finais de $1641\left(^{54}\right)$, Descartes tinha contactado Elzevier para fazer uma nova edição da sua obra. Tal iniciativa deve-se fundamentalmente ao facto que o editor francês não tinha enviado ao autor nenhum dos exemplares que este pedira. Assim, sabemos que em 19 de Janeiro de 1642, Descartes ainda não tinha recebido nenhum dos cento e trinta exemplares que pedira ao editor $\left.{ }^{55}\right)$.

A nova edição, impressa na Holanda, seria restringida ao mercado holandês. Ela apareceu nos primeiros dias do mês de Maio. Constantin Huygens, que entre 19 e 23 do mesmo mês, viajava de Haia para Amsterdam, constatou as edições e as modificações desta segunda edição $\left({ }^{56}\right)$.

Fundamentalmente, as modificações consistiam no título, e as adições na introdução das sétimas objecções e respostas - que oportunamente Descartes comunicara a Huygens $\left({ }^{57}\right)-$, objecções essas da autoria de Bourdin, professor do Colégio de Clermont em Paris, autor de teses contra o Discurso de 1637. Seguia-se nesta nova edição, uma carta a Dinet, superior hierárquico de Bourdin.

(C3) Para não sobrecarregar a tipografia, não seguiremos nas nossas enumerações das peças das diferentes edições as disposições tipográficas das mesmas.

$\left({ }^{54}\right)$ Cf. A.T. III. 448.

(55) Cem desses exemplares destinavam à venda e trinta destinavam-se aos amigos do autor; cf. A.T. III. 482. 1. 22.

$D$ Cf. Carta de 26 de Maio 1642, A.T. III. 564. 1. 11-17 e Charles Adam, A.T. XII. 303.

( ${ }^{57}$ Carta a Huygens de 31 de Janeiro 1641, A.T. III, 523. 1. 6-12. 
A propósito destas novas peças, é importante notar que Mersenne tinha dado a conhecer desde 1640 o manuscrito das Meditações a várias individualidades que só tardiamente apresentaram as suas objecções. Além de Bourdin, encontramos entre essas individualidades, Jean Ferner, - que ainda sob o efeito da polémica desencadeada a propósito dos Ensaios de 1637, declinou o convite $\left({ }^{58}\right)$ de Mersenne-, Gibieuf, e aquele que se autodenominava o Hyperaspistes. Os quatorze pontos das objecções do Hyperaspistes, receberam uma resposta minuciosa ${ }^{59}$ ) que Descartes chegou mesmo a pensar em integrar na edição de 1642. Quanto a Gibieuf, ele teve as respostas às suas objecções em 19 de Janeiro de $1642\left({ }^{60}\right)$.

2.2. A segunda edição latina apareceu com o seguinte título:

RENATI I DES-CARTES, | MEDITATIONES | DE Prima ' PHILOSOPHIA I In quibus Dei existentia, \& animae | humanae à corpore distinctio, | demonstrantur. | His adjunctae sunt variae objectiones docto - $\mid$ rum virorum in istas de Deo \& anima I demonstrationes; | Cum Responsionibus Authoris. | Secunda editio septimis objectionibus antehoc|non visis aucta. I Seguido de: Amsterdam, Louis Elzevier, 1642.

2.3. Esta edição, que segue disposições tipográficas idênticas à edição de 1641 , contém as seguintes peças:

a) prefácio ao leitor; b) sinopsis das seis meditações; c) texto das meditações; d) sete séries de objecções e de respostas, sendo as sétimas objecções publicadas após uma nova página de título e com as respostas do autor intercaladas; e) a carta a Dinet termina o volume.

3.A. Desde a sua viagem a França em 1644, Descartes tomou conhecimento da existência de uma tradução da sua obra feita pelo duque de Luynes $\left({ }^{61}\right)$. Ë nessa altura que Descartes pede a Claude Clerselier, de acrescentar a «version des objections et de leur réponse à la traduction fidèle et ex-

(M) Cf. A.T. III. 328. 1. 1-14; 332-333 e A.T. XII. 298.

O A.T. III. 421-435.

C) Alq. II. 904-910.

$\left.{ }^{6}{ }^{1}\right)$ Filho do ministro de Luis XIII. 
cellente de ses Méditations, dont un Seigneur de très grande considération lui avait fait présent» $\left({ }^{62}\right)$.

Segundo Adrien Baillet, primeiro biógrafo de Descartes, foi o sucesso obtido com a publicação des Principia Philosophiae $\left({ }^{63}\right)$ que impulsionou Descartes a publicar uma edição francesa da sua obra $\left({ }^{64}\right)$.

As duas traduções foram revistas pelo autor. Baillet fornece-nos algumas precisões sobre as datas e sobre o processamento das revisões. Assim, sobre as datas, Baillet nota: «Pour ne rien omettre de ce qui peut regarder la traduction des Méditations, il suffit de remarquer qu'encore qu'elle ait été faite en 1642, néanmoins la révision ou la correction par M. Descartes ne s'en fait qu'en 1645 , et que la première impression qui en fut faite à Paris ne fut en état de paraître que pour les étrennes de l'an 1647 » ${ }^{(65)}$. Referindo-se à revisão ou correcção, Baillet diz-nos que Descartes aproveitou essa ocasião «pour retoucher son original en notre langue» $\left({ }^{66}\right)$, mais precisamente: «Sous prétexte de revoir ces versions, il se donna la liberté de se corriger lui-même et d'éclaircir ses propres pensées. De sorte qu'ayant trouvé quelques endroits où il croyait n'avoir pas rendu son sens clair dans le latin pour toutes sortes de personnes, il entreprit de les éclaircir dans la traduction par quelques petits changements qu'il est aisé de reconnaître à ceux qui confèrent le français avec le latin» $\left({ }^{67}\right)$.

A propósito do acolhimento que Descartes reservou às traduções, Baillet acrescenta: «M. Descartes témoigna être si satisfait de lune et de l'autre version qu'il ne voulu point user de la liberté qu'il avait pour changer de style, que sa modestie et l'estime qu'il avait pour ses traducteurs lui faisaient trouver meilleur que n'aurait été le sien» $\left({ }^{68}\right)$.

Encarregado por Descartes, da impressão e da distribuição dos exemplares $\left({ }^{69}\right)$, Clerselier, contrariamente à vontade

(') Avertissement du traducteur, A.T. IX. 200.

(63) Amsterdam, L. Elzevier, 10 juin 1644, cf. A.T. VII.1-329.

( ${ }^{64}$ Cf. Baillet, V.D., II. 265, citado em A.T. IV. 176-177.

- L. $M M_{.,}$p. XI.

(65) Cf. Baillet, V.D., II. 173, citado em A.T. IV. 195, e G.R. -

(66) Cf. Baillet, V.D., II. 172.

$\left({ }^{67}\right)$ Ibidem, citado em A.T. IV. 194.

$\left({ }^{68}\right.$ Ibidem, citado em A.T. IV. 192 e G.R.-L., M.M., p. XIII.

( $\left.{ }^{60}\right)$ Cf. Baillet, V.D., II, 324, citado em A.T. V. 563-564 e

G.R.-L., M.M., p. XI. 
do autor, incorporou à edição as quintas objecções e respostas. Esta peça, é a única que na edição de 1647 não foi revista por Descartes.

3.2. A primeira edição francesa da obra apareceu com o título:

LES I MÉDITATIONS | MÉTAPHYSIQUES | DE RENÉ DES-CARTES | TOUCHANT LA PREMIĖRE PHILOSOPHIE, $\mathrm{j}$ dans lesquelles Inexistence de Dieu, et la distinction réelle entre | Tâme et le corps de Thomme, sont démontrées. Traduites du Latin de VAuteur par $M^{r}$ le D. D. L. N. S. | Et les Objections faites contre ces Méditations par diverses | personnes très - doctes, avec les réponses de TAuteur. | Traduites par $M^{r}$ C.L.R. Segue-se: A PARIS, | Chez la Veuve IEAN CAMUSAT, | ! ET I PIERRE LE PETIT, Imprimeur ordinaire du Roy, | ruë S. laques, à la Toyson d'Or. | M. DC. XLVII. | AVEC PRIVILËGE DU ROY $\left({ }^{70}\right)$.

\subsection{Esta edição contém as seguintes peças:}

a) Carta ao Decano e Doutores da Faculdade de Teologia de Paris; b) O livreiro ao leitor; c) resumo das seis meditações; d) texto das seis meditações; e) seguem-se as quatro primeiras objecções e resposta; f) um aviso do autor; g) um aviso do tradutor; h) as sextas objecções e respostas; i) as quintas objecções e respostas; j) e por fim, uma carta a Clerselier que serve de resposta às Instâncias de Gassendi.

4.1. Entre os títulos das edições de 1641 e de 1642 notamos algumas divergências importantes $\left({ }^{71}\right)$. A primeira, que a história das ideias consagrou através de um numero considerável de comentários, que aparecem desde o tempo de Descartes, é particularmente patente: enquanto a edição de 1641 anuncia: in qua Dei existentia | et Animae immortalitas I demonstratur, a edição de 1642 anuncia simplesmente: In quibus Dei existentia, \& animae | humanae a corpore distinctio,

$\left({ }^{70}\right)$ Privilégio reproduzido in A.T. IX. 245. 1 e 127-128.

(") Para uma comparação dos títulos, cf. A.T. VII. pp. XVIII, 
I demonstrantur $\left({ }^{72}\right)$. Uma segunda divergência deve-se ao facto de, enquanto a edição de 1641 omite a referência às objecções e às respostas de Descartes, a segunda edição especifica: His adjunctae sunt variae objectiones docto - | rum virarum in istas de Deo \& anima | demonstrationes; [ Cum Responsionibus Authoris.

4.2. O título da segunda edição anuncia ainda uma peça inexistente na edição de 1641: Secunda editio septimis objectionibus antehoc $\mid$ non visis aucta $\left({ }^{73}\right)$.

4.3. Do título da segunda edição desaparece a menção que figurava na página de título da primeira edição: Cum Privilegio \& Approbatione Doctorum.

4.4. Quanto à tradução do título, a tradução francesa de 1647, segue visivelmente a correcção introduzida pela edi-

${ }^{72}$ ) Na segunda edição, desaparece do título a referência à demonstração da imortalidade da alma. Tal supressão visa certamente ressituar a razão no seu próprio terreno: só se demonstrará aquilo que a razão natural permite demonstrar. A ressituação sobre o terreno da razão é correlativa da real territorialidade do público a quem esta edição se destina: o público da Holanda Protestante. Talvez o recuo patente no título da ed. de 1642 possa contribuir para provar que Descartes nunca teve a intenção de provar aquilo que o título anunciava.

Deixando em aberto a questão da sinceridade religiosa do autor, parece-nos importante notar que no tratamento da mesma não deveria ser omitida a consideração do debate polarizado em torno dos parâmetros fé e razão, problemática amplamence representada nas diferentes obras do autor e de modo particularmente insistente ao longo da sua correspondência.

Para esclarecer a questão acima indicada, será também necessário entrar em linha de conta com as relações estabelecidas no séc. XVII entre saberes e poderes: apesar dos esforços feitos quer por Gibieuf, da Companhia do Oratório, professor na Sorbonne, cf. A.T. III. 237-238, 276, 388, 416, 419, quer por Mersenne, no sentido de obterem uma aprovação da Faculdade de Teologia, sabe-se que tal aprovação nunca chegou a ter lugar (cf. A.T. XII, 303 e 305-306). Fundamentalmente, tal aceitação deveria proteger o autor da censura da Inquisição. Nesta perspectiva estamos face a uma estratégia institucional que consistia em opor a autoridade de duas instâncias de poder. Daí a concluir da insinceridade religiosa do autor parece-nos infundado. Sobre esta questão, cf. notas 229 e 230 . Um dos estudos mais rigorosos sobre esta questão podemos encontrá-lo em Henri Gouhier, La pensée religieuse de Descartes, Paris, J. Vrin, 1924, p. 328. Sobre os mecanismos da censura, cf. Émile Narner, L'affair Galilée, Paris, Gallimard/Julliard, 1975, p. 266; Madeleine Cerf, «La Censure, royale à la fin du XVII ${ }^{\mathrm{e}}$, Communications, n..$^{\circ}$ 9, pp. 2-27, Paris, Seuil, 1967. (Embora este estudo tenha como tema o séc. XVIII, ele estabelece uma importante comparação com a censura no séc. XVII).

$\left({ }^{73}\right)$ Cf. A.T. VII. 451-561; Alq. II. pp. 947-1073. 


\section{Antonio Sérgio}

ção latina de 1642. Assim, a página de título anuncia: dans lesquelles l'existence de Dieu, et la distinction réelle entre j l'âme et le corps de l'homme, sont démontrées.

4.5. Na edição francesa aparece ainda menção das iniciais dos nomes dos tradutores: Traduites du Latin de VAuteur par $M^{r}$ le D.D.L.N.S. Et les Objections... avec les réponses de l'Auteur. | Traduites par Mr C.L.R.

Nesta página de título encontramos ainda a menção: AVEC PRIVILE GE DU ROY.

4.6. Em relação às peças da primeira edição, a edição de 1642 apresenta divergências consideráveis: a) suprime o Index que figurava no início do volume de 1641 ; b) suprime ainda a carta intitulada: SAPIENTISSIMXS CLARISSIMISQUE VIRIS I SACRAE FACULTATIS THEOLOGUIAE PARISIENSIS I DECANO \& DOCTORIBUS | RENATUS DES CARTES S. D.

4.7. A segunda edição suprime ainda as duas últimas páginas da edição de 1641 , respectivamente o extracto do privilégio do rei e a Errata $\left({ }^{74}\right)$.

4.8. Em relação à edição de 1641 , a edição de 1642 acrescenta: a) Objectiones septimae in Meditationes de prima Philosophia cum notis Authoris, peça que pela sua numeração particular tende a formar um corpus autónomo dentro do corpus geral; b) a peça anterior é imediatamente seguida de uma outra com o título: Admodum Reverendo Patri, Patri Dinet, Societatis Jesu Praeposito provinciali per Franciam Renatus Des Cartes S.D.

4.9. Em relação à edição de 1642 , a tradução francesa restabelece a carta dirigida às autoridades da Sorbonne sob 0 título: A Messieurs les Doyen et Docteurs de la Sacrée | Faculté de Théologie de Paris.

4.10 Relativamente às duas edições latinas a tradução acrescenta as seguintes peças: a) LE LIBRAIRE AU LECTEUR; b) Avertissement de l'Auteur; c) Avertissement du Traducteur; d) e uma carta de 12 de Janeiro de 1646 imnressa sob o título: LETTRE I De M. DESCARTES A M. CLERSELIER, | SERVANT DE REPONSE A UN RECUEIL DES PRINCIPALES | 1 INSTANCES FAITES PAR MONSIEUR GASSENDI CON-

( $\left.{ }^{M}\right)$ Cf. ob. cit., pp. 603 e 604. 
TRE I LES PRÉCÉDANTES RÉPONSES. Esta última peça constitui a resposta à obra que Gassendi publicou sob o título: Disquisitio Metaphysica, seu Dubitationes et Instantiae adversus Renati Cartesii Metaphysicorum et Responsa, Amsterdam, 1644, (edição feita ao cuidado de Sorbière) $\left({ }^{75}\right)$.

4.11. Em relação à segunda edição latina, a edição francesa de 1647, suprime: a) Objectiones septimae....; b) e Admodum Reverendo Patri, Patri Dinet....

5. Principais edições das Meditações, anteriores a 1930.

\subsection{Clerselier, 1661.}

No início da segunda metade do séc. XVII, Claude Clerselier publicou uma nova edição integral das Meditações de Descartes. Nesta edição, a primeira efectuada após a morte de Descartes, o seu editor introduziu não só as suas traduções das quintas objecções e respostas, — já editadas em 1647 contra a vontade de Descartes -, mas também as traduções das sétimas objecções e respostas e da carta a Dinet, peças não editadas na primeira edição francesa.

Dado que Clerselier produziu importantes correcções, não só nas suas traduções, mas também na tradução de Luynes, - ambas revistas, alteradas e adoptadas por Descartes antes da sua primeira publicação - , esta edição é actualmente considerada como um apócrifo, e como tal imprópria para apoiar estudos aprofundados.

Seria importante notar, que esta edição de Clerselier, foi reproduzida por R. Fédé em 1673. Nesta nova edição, o editor aproveitou a ocasião para dividir o texto em parágrafos. Adrien Baillet, considerou esta nova edição como a mais útil e a mais perfeita de todas.

\subsection{Victor Cousin, 1824.}

O texto das Meditações que V. Cousin publicou na sua edição das Oeuvres Completes de Descartes $\left({ }^{76}\right)$, edição que

$\left.{ }^{7 D}\right)$ Cf. Pierre Gassendi, Disquisitio metaphysica.... Recherches métaphysiques ou doutes et instances contre la métaphysique de $R$. Descartes et ses réponses. Texte établit, traduit et annoté par B. Rochot, Paris, J. Vrin, 1962, XIV e 658 p.

${ }^{76}$ ) Oeuvres complètes de Descartes, 12 vol. in-8, Paris, Levrault, 1824-1826. Nesta edição, o texto francês é publicado no tomo I. 
tem o mérito de ser a primeira quase-completa, contém tal como as restantes peças da edição - um número apreciável de erros paleográficos. O principal defeito deste texto das Meditações é a sua própria fonte: trata-se de uma reprodução da edição Clerselier transformada por R. Fédé. Como o próprio editor o reconheceu $\left({ }^{77}\right)$, os erros materiais da sua publicação tornam-na inapta para servir de base a um trabalho de investigação $\left({ }^{78}\right)$.

\subsection{Adam \& Tannery, 1904.}

Impulsionada por Emile Boutroux $\left({ }^{79}\right)$ no quadro das comemorações do terceiro centenário do nascimento de Descartes, a edição estabelecida por Charles Adam e Paul Tannery, tinha como principal objectivo pôr à disposição do público um instrumento paleograficamente correcto, e portanto susceptível de servir de apoio à investigação. Nesta edição, os textos latino e francês das Meditaçốes ocupam respectivamente os tomos VII e IX.

5.3.1. Para a sua edição do texto latino, os editores escolheram a edição de 1642. As principais razões dessa escolha são as seguintes: a) o texto da primeira edição, impresso em Paris, longe da vigilância de Descartes, apresenta, segundo A.T., um grande número de erros de impressão. Esses erros dever-se-iam ao facto que Descartes não teria tido a oportunidade de rever as provas $\left({ }^{80}\right)$.

Nas suas Correcções e Adições, publicadas no final do tomo VII $\left({ }^{81}\right)$, os editores rectificam alguns dos pontos que os conduziram à escolha da edição de 1642 como referência da nova publicação, declarando que com efeito, alguns dos erros atribuídos ao texto impresso em 1641, não constam nessa

$\left.{ }^{7 T}\right)$ Cf. A.T. I. p. LXII.

$\left.{ }^{78}\right)$ Um dos principais inconvenientes desta edição advém do facto de ela não apresentar nenhum texto latino. Tal omissão está na base da apreciação de Charles Adam: «Et puis, c'était moins une oeuvre d'érudition que de propagande» A.T. I. LXII. Sobre a edição V. Cousin cf. A.T. I, p. V e LXII-LXVI.

$\left.{ }^{7 \mathrm{U}}\right)$ Emile Boutroux anuncia o acontecimento na Revue de Métaphysique et de Morale, du 15 mai 1894. Dois anos depois a mesma revista consagrava um número exclusivo a Descartes, R.M.M., du 15 juillet 1896.

D A.T. VII, p. XIII.

${ }^{81}$ A.T. VII, pp. 605-608. 
edição. Todavia, nessa mesma nota, os editores alegam, - sem qualquer precisão suplementar-, que a edição de 1641 teria tido duas tiragens, e portanto, que erros que figuram numa dessas tiragens foram corrigidos na outra. Além disso, a nota em questão atribui novas gralhas à edição de 1641 sem todavia mencionar que tais gralhas também aparecem na edição de $1642 ;$ b) a edição A.T. segue portanto o texto latino de 1642, o único que segundo os editores teria sido revisto pelo autor. Todavia, os editores nunca assinalam os pontos em que se afastam do texto de 1642 .

De notar ainda que, dado o facto que os textos das primeira e segunda ediçốes latinas só terem parágrafos nas duas últimas meditações, A.T. estabeleceram uma divisão em parágrafos destinada a facilitar a leitura $\left({ }^{82}\right)$.

5.3.2. Na edição do texto francês das Meditações, A.T. seguiram como referência o texto adoptado - corrigido e aumentado - pelo autor e editado em 1647, fazendo no entanto desaparecer as traduções Clerselier das quintas e sétimas objecções e respostas assim como da carta a Dinet $\left({ }^{83}\right)$.

\section{Principais edições das Meditações de Descartes, pos- teriores a 1930.}

\subsection{Geneviève Rodis-Lewis, 1946.}

Esta edição bilingue das MeditationesIMéditations, pela sua inteligente disposição gráfica e pela sua criteriosa anotação paleográfica-histórico-conceptual, tornou-se um instrumento indispensável aos estudos sobre Descartes.

Privando-se de encontrar na ocasião de tal edição o momento de publicar uma ou um conjunto de teses de carácter filosófico e resistindo ao impulso que conduz muitos editores-tradutores a escrever resumos da «história» da filosofia, - muitas vezes determinados por motivos demasiado imediatos —, a autora desta edição optou por concentrar o seu erudito conhecimento da Obra de Descartes $\left({ }^{84}\right)$ numa breve

\footnotetext{
${ }^{82}$ Cf. A.T. VIL pp. XV-XVIII.

${ }^{83}$ ) A edição A.T. só apresenta textos aprovados pelo autor.

O Geneviève Rodis-Lewis, além de numerosos artigos dedicados ao estudo do pensamento de Descartes publicou as seguintes obras sobre o autor: Discours de la méthode, suivi d'extraits de la Dioptrique, des Météores, de la vie de Descartes par Baillet, du Monde,
} 
Introdução histórica e numa anotação minuciosa orientada segundo os eixos da paleografia, da história e da semântica do texto cartesiano.

Assim, esta edição que visivelmente não se sente vocar cionada para decidir qual dos textos, latinos ou francês, é aquele que do ponto de vista conceptual é o bom texto, toma como ponto de partida as edições de A.T., dos quais reproduz em margem a paginação.

As divergências, importantes, que separam o texto de 1642 do texto de 1647 , são expressas graficamente na edição G. Rodis-Lewis pelo recurso a caracteres itálicos. A título complementar a editora anota as divergências existentes entre as duas edições latinas e entre as duas traduções de Clerselier, respectivamente de 1647 e 1661 . Esta última edição, afastada como texto de base, é todavia utilizada, não só para a anotação, como para apoiar a leitura do Praefatio ad lectorem, peça ausente da edição de 1647.

Para os esclarecimentos relativos à história e à semântica, os dados utilizados nesta edição provêm de dois grupos de fontes: a Obra de Descartes, - mais particularmentt a Correspondência e o Entretien avec Burman -, e um segundo grupo constituído por dicionários da época, obras de autores escolásticos, com influência incontestável na formação e no desenvolvimento do pensamento de Descartes, e ainda duas obras de Etienne Gilson: o Index scolastico-cartésien e o Commentaire au Discours de la méthode $\left({ }^{85}\right)$, duas obras dis-

\subsection{F. Alquié, 1967.}

Tal como as edições A.T. e G.R.-L., a edição Alquié põe à disposição dos estudiosos um texto latino e um texto francês das Meditações.

6.2.1. A edição Alquié do texto latino, apresenta como principais particularidades os factos de suprimir todas as

de l'Homme et de lettres, chronologie et préface, Paris, Garnier - Flammarion, 1966; U individualité selon Descartes, Paris, J. Vrin, 1950, 241 p.; La morale de Descartes, Paris, P.U.F., 1957', 1962 ${ }^{\mathrm{a}}$; L'Oeuvre de Descartes, 2 t., Paris, J. Vrin, 1971, 575 p.

(") Etienne Gilson, Index Scolastico-cartésien, Paris, J. Vrin, $1979^{2}$ (édition revue et augmentée; a primeira edicão desta obra data de 1913, Paris, Felix Alcan); Discours de la méthode, texte et commentaire, Paris, J. Vrin, 1925; Etudes sur le rôle de la pensée médiévale dans la formation du système cartésien, Strasbourg, 1921 ${ }^{1}$, Paris, J. Vrin, 1930 e 1951, 338 p. 
poníveis respectivamente desde 1913 e 1925, obras indispensáveis a todo o estudo da genética, história e transformações dos conceitos com os quais Descartes opera ao longo das suas obras.

peças introdutórias e de proceder a uma minuciosa comparação dos textos das edições de 1641 e de 1642.

Tal investigação consistiu em comparar todos os exemplares disponíveis em França e no estrangeiro de cada uma das edições latinas. Nesta árdua tarefa, F. Alquié foi adjuvado por Henri Gouhier e Leslie Beeck.

$\mathrm{O}$ resultado do inquérito foi o seguinte: a) existem efectivamente alguns exemplares da edição de 1641 que contêm alguns dos graves erros que A.T. assinalam. L. Beeck encontrou em Inglaterra dois desses exemplares; b) L. Beeck encontrou igualmente em Inglaterra um exemplar da edição de 1641 no qual algumas das páginas estão corrigidas.

A consideração destes factos, conjugada com a análise detalhada de dois blocos da correspondência de Descartes, referente aos meses que antecedem a publicação da primeira edição latina das Meditações, conduziu F. Alquié à formulação de conjecturas, que, como veremos contrariam ponto por ponto as opções de A.T.

Assim, por um lado, temos a correspondência trocada entre Descartes e Huygens, publicada peia primeira vez por Léon Roth em $\left.1926{ }^{8 t}\right)$ - e portanto desconhecida de A.T.a qual revela uma carta datada de 29 de Julho na qual Descartes estabelece uma lista dos principais erros de impressão, anotando-os com referência à página e à linha. Entre esses erros, encontramos alguns que A.T. assinalaram nas peças terminais da sua edição.

Seguindo o segundo bloco de correspondência, estabelecem-se com relativa segurança respectivamente as datas de envio a Mersenne das respostas às quintas e sextas objecções: 23 de Junho e 23 de Julho de 1641. Dado que se conhece a data na qual se terminou a impressão da primeira edição, 28 de Agosto, tudo leva a pensar que entre os finais do mês de Julho, mais precisamente, desde a carta a Huygens até à aparição da obra, o livreiro tenha procedido à rectificação da maior parte das rectificações que Huygens lhe comunicou.

$\left.{ }^{8 \mathrm{C}}\right)$ Léon Roth, Correspondance of Descartes \& Huygens (1635-1647), Oxford, Clarendon Press, 1926. 
Neste caso, as rectificações que figuram na Errata da edição de 1641, são algumas das que o autor assinalou, mas que por alguma razão não puderam ser feitas.

Resta clarificar o facto de alguns dos exemplares conterem um número considerável de erros e ainda o da aparição de um exemplar parcialmente corrigido. Tais factos conduziram F. Alquié a pensar que as correcções tiveram lugar, sobre a maior parte dos exemplares, já num período tardio da brochagem, e que tais correcções consistiram fundamentalmente em intercalar novas páginas na impressão existente. Assim, teriam saído da oficina do impressor, obras não corrigidas, outras que o foram parcialmente e outras ainda que o foram em conformidade com as indicações de Descartes.

São estes argumentos que fundamentam a refutação de

F. Alquié, relativamente aos argumentos que A.T. apresentaram para justificarem a sua adopção do texto de 1642 como texto de referência. Alquié estabelece: a) Descartes corrigiu o texto desta edição como o prova a carta a Huygens; b) a edição de 1641 não teve duas tiragens mas sim uma correcção feita durante a brochagem.

Do exame paleográfico detalhado da segunda edição latina, Alquié pode concluir: a) todos os exemplares examinados continham os erros assinalados por A.T.; b) muitos desses erros derivam da impressão defeituosa da edição de 1641 ; c) consequentemente, que a edição de 1642 não foi feita a partir de um novo manuscrito - tal como A.T. defenderam —, mas sim a partir de um exemplar corrigido da edição de 1641.

6.2.2. Foram as razões anteriormente expostas que conduziram F. Alquié a não publicar nem o texto de 1641 nem o da segunda edição, mas sim um híbrido sintetizado a partir de um cotejo esmerado de todos os exemplares disponíveis das edições princeps.

Seguindo a pontuação e a divisão em parágrafos estabelecidos por A.T., F. Alquié faz reproduzir nas margens do seu texto a paginação de A.T. Quanto à anotação do texto latino, elas visam exclusivamente o seu restabelecimento paleográfico, omitindo portanto todas as referências quer à sua história quer à sua semântica.

6.2.3. Quanto ao texto francês da edição Alquié, ele é fiel à tradução de Luynes, mesmo se o editor restitui em francês moderno o francês de Descartes e introduz algumas modificações na ortografia suprimindo por exemplo as maiús- 
culas de certas palavras $\left({ }^{87}\right)$. A anotação não só indica todas as divergências existentes entre o texto latino e a sua tradução francesa, aspecto no qual o editor se serve da edição de G. Rodis-Lewis, e fornece elementos destinados a promover uma mais ampla elucidação do texto, elementos esses fornecidos pela Obra de Descartes e alguns textos da mesma época. Assim se constitui um aparato histórico-conceptual precioso que torna obrigatória a consulta desta edição $\left({ }^{88}\right)$.

Para as restantes peças da sua edição, F. Alquié segue as traduções Clerselier de 1647. As traduções das peças não incluídas na primeira edição francesa - prefácio latino, quintas e sextas objecções e respostas e carta a Dinet-, provêm da edição Clerselier e da sua reprodução, por vezes ligeiramente transformadas por Alquié para as aproximar do latim do autor. Por vezes, F. Alquié, produz igualmente cortes-resumos de algumas passagens deste último grupo de objecções, reproduzindo, no entanto, integralmente as respostas de Descartes.

\subsection{Cogito 75 .}

6.3.1. A edição de André Robinet designada por Cogito $\left.75{ }^{89}\right)$, resulta de uma colaboração interdisciplinar que pela aplicação da informática a um texto de filosofia - o texto

trie.

$\left.{ }^{8 T}\right)$ Soleil, Géométrie, etc., são modificados para soleil, géomé-

$\left.{ }^{88}\right)$ Contrariamente às controvérsias estéreis que a questão pode levantar, - controvérsias essas cheias de sentido(s) inconfessado(s) F. Alquié, G. Rodis-Lewis, Adam \& Tannery e alguns outros editores, consideram a edição francesa de 1647 como um texto autentic ament $e$ cartesiano. Sobre este assunto, F. Alquié sublinha que, como legitimamente cartesiana, a tradução da obra deve ser datada de 1647 e não de 1641, e isso mesmo e segundo ele, «le texte français de 1647 est une version fidèle du texte latin de 1641» (Alq. II. 378). Julgamos esta afirmação excessiva: quando Descartes corrige a versão francesa, ele não pode deixar de ter em conta problemas que a sua obra suscita desde 1641, e por outro lado, como $F$. Alquié o não ignora, entre os anos de 1641 e 1647, o pensamento de Descartes apresenta certas inovações; cf. as cartas a Mesland de 9 février 1645, Alq. III. 544-550 e 551-553 e as de mai 1645 e mars 1645 ou 1646, respectivamente em Alq. III. 569-570 e 629-631.

$\left({ }^{89}\right)$ René Descartes, Cogito 75. Méditations Métaphysiques. Texte définitif avec indexation automatisée, tableau alphabétique des formes lexicales, tableau fréquentiel, concordances, tableau des co-occurrences, sous la direction d'André Robinet, avec collaboration d'Anne Becco, Cl. Machgeels, René Patesson, Ghislaine Vire, Paris, J. Vrin-C N.R.S., 1976. VIII - 141 p. 
francês das Méditations de Descartes - pôs ao alcance dos historiadores das ideias e da filosofia, uma arma pré-hermenêutica, pré-semântica, constituída exclusivamente por factos lexicais estabelecidos a partir de uma paleografia escrupulosa.

Tal levantamento lexicográfico tem como primeiro referente paleográfico a tradução de Luynes e como adjuvante a restituição feita por F. Alquié da ortografia de Descartes em ortografia moderna. Todavia, dada a importância atribuída por esta nova metodologia à restituição exacta da letra, o editor, achou importante restabelecer certas capitais $\left({ }^{90}\right)$ suprimidas na edição de F. Alquié, assim como manter certas expressões próprias ao francês de Descartes $\left.{ }^{91}\right)$, restaurando ainda pretéritos perfeitos simples $\left({ }^{92}\right)$ transformados por F. Alquié em imperfeitos.

O texto submetido ao tratamento informático é constituído pelo resumo e pelas seis meditações.

Além do texto em questão $\left({ }^{93}\right)$, Cogito 75 , apresenta um conjunto de seis índices que passamos a descrever.

\subsection{2. $\quad O$ índice $I$, apresenta os relevos lexicais gerais do} texto completo, distinguindo da totalidade das formas $\left({ }^{94}\right)$, as formas lexicalizadas das formas funcionalizadas e apresentando para cada um dos três casos o número de formas correspondentes. Segue-se um cálculo dos coeficientes de funcionalidade, lexicalidade, repetividade funcional, repetividade lexical e repetividade geral.

Dada a sua importância, reproduzimos esses dados $\left({ }^{95}\right)$ :

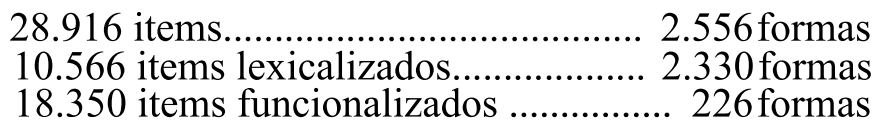

( $(>0)$ Soleil, Géométrie, Aritmètique, etc...

$\left({ }^{\prime}\right)$ Tais como, «pour ce que» e outras similares.

$\left({ }^{2}\right)$ Passés composés.

C) Cf. ob. cit., pp. 1-65.

${ }^{\mathrm{M}}$ ) Forma: toda a unidade gráfica separada de unidades vizinhas por um espaço branco da tipografia. Cf. R. Busa, Revue de l'Organisation internationale pour l'étude des langues anciennes à l'ordinateur, Liège, Belgique, n. ${ }^{\circ}$ 2, 1969, p. 41.

$\left({ }^{5}\right)$ Cf. Cogito 75 , p. 67. Para uma definição do item, cf. Dictionnaire de la linguistique, sous la direction de Georges Mounin, Paris, P.U.F. 1974, p. 185.

Designando os items por i e os items funcionalizados por if, o

coeficiente de funcionalidade calcula-se pela formula ---_-_ if 
Cálculo de coeficientes:

Funcionalidade 63,460

$\%$

Lexicalidade $36,540 \%$

Repetividade funcional 81,195

Repetividade lexical $j_{\text {no }}$ Repetividade geral $4,535 \cdot \hat{h}$ [ntos

Um conjunto similar de dados é estabelecido relativamente a cada uma das sete peças do conjunto $\left.{ }^{96}\right)$. Eles permitem seguir detalhadamente as micro flutuações do léxico do autor segundo a repartição estrutural da obra.

6.3.3. No Índice II, são apresentadas segundo ordem alfabética todas as formas com indicação da sua totalidade, distribuição e situação no corpus $\left({ }^{97}\right)$. Esta última referência é feita segundo o sistema meditação-página-linha $\left({ }^{98}\right)$. De notar ainda que este Índice individualiza todos os grupos de formas homógrafas (").

6.3.4. O Índice III, fornece um quadro onde as duzentas formas mais frequentes do vocabulário do autor aparecem dispostas de modo piramidal, por ordem decrescente de

do os items lexicalizados por $i l$, o coeficiente de lexicalidade calcula-se pela fórmula $-\frac{\text { it }}{\mathrm{i}}$; designando as formas funcionais por $F f$, $o$ coeficiente de repetividade funcional calcula-se pela fórmula $-\frac{\text { if }}{\text { Ff }}$; designando as formas lexicalizadas por $F l$, $o$ coeficiente de repetividade lexical calcula-se pela fórmula -_-_

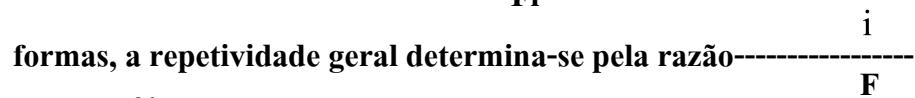

$\mathrm{C}^{96}$ ) Cf. ob. cit., pp. 66-67.

$\left.{ }^{9 T}\right)$ Cf. ob. cit., pp. 68-114.

(98) O resumo é designado por zero e as meditações pelos algarismos árabes de um a seis. Assim, 2.12.25, designa a meditação segunda, a página número doze e a linha número vinte e cinco. Cada uma destas referências envia directamente ao corpo do texto que na sua margem indica o número de ordem de cada linha.

(") Por exemplo aquelas que nominalmente e adjectivamente ou ainda aquelas que sob a forma de verbo ou de substantivo são graficamente idênticas. 
frequência. Esse quadro hierarquiza diferencialmente as formas ditas funcionais e as formas lexicais. A sua principal virtude é a de permitir uma rápida comparação das mobilizações lexicais postas em jogo em diferentes obras por um mesmo autor, ou ainda comparar léxicos de autores diferentes $\left({ }^{10 \circ}\right)$.

6.3.5. O Índice $I V$, fornece oito quadros de coeficientes de frequência, um relativo ao texto completo e sete outros relativos a cada uma das peças $\left({ }^{101}\right)$. Estes quadros, na medida em que eles dão a ver a importância que o autor atribui a cada um dos termos que utiliza em cada uma das partes do seu discurso, permitem uma fina penetração das disposições arquitectónicas da sua construção. Tal tipo de dados permite igualmente cotejar com grande facilidade os suportes lexicais de autores diversos ( ("ü2).

6.3.6. O índice $V$, apresenta um extracto $\left({ }^{103}\right)$ das tabelas de concordâncias lineares diacríticas nas quais são facilmente discerníveis algumas associações lexicais típicas da linguagem do autor e colocadas por este ao serviço da comunicação do seu pensamento. Tais tabelas constituem uma ficha-texto, que facilitando uma primeira aproximação do contexto da ocorrência, lançam o leitor nos caminhos da hermenêutica e da semântica.

6.3.7. O Índice VI, exibe quadros das co-ocorrências de algumas das formas do léxico do autor $\left({ }^{104}\right)$. Neles, é indicada sob a forma de pirâmide aritmética a proximidade em número de items, a totalidade dos termos situados respectivamente dez items à esquerda e à direita dos termos-polo considerados. Este tipo de tabelas que dá a ver as satelizações opera-

(10\%) Cf. André Robinet, «Malebranche et Leibniz à l'ordina-

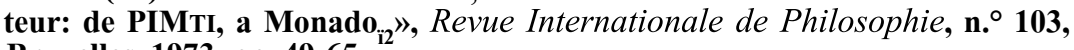
Bruxelles, 1973, pp. 49-65.

(101) Cf. ob. cit., pp. 117-120.

(102) f necessário justificar o facto que este último tipo de comparações tem a sua maior pertinência quando as comparações são feitas entre autores de uma mesma época.

$\mathrm{O}^{03}$ ) Cf. ob. cit., pp. 121-132.

$\left({ }^{104}\right)$ Cf. ob. cit., pp. 133-140. Essas formas são as seguintes: pense (forma verbal da primeira pessoa), pense (forma verbal da terceira pessoa), substance e substances. 
das nas imediações das constelações lexicais próprias ao autor, constitui a base mais segura de uma aproximação semiótica do seu sistema-galáxia.

7. Tendo como postulados subjacentes uma paleografia minuciosa e uma informática speciosa $\left({ }^{105}\right)$, a informática aplicada aos textos filosóficos fornece factos exaustivos indispensáveis quer à hermenêutica quer à história das ideias, disciplinas que correlacionadas com as precedentes são a base indispensável de um trabalho de tradução.

São alguns destes os pontos que passamos a tratar.

7.1. Os problemas inerentes à sua paleografia são os principais que toda a edição crítica encontra. Com efeito, a paleografia requer a convergência de múltiplas competências que nem sempre um só indivíduo reúne. Este trabalho fundamentalmente interdisciplinar, resultado da colaboração de lexicólogos linguistas, filólogos, hermeneutas, historiadores e muitas vezes de especialistas em química, têm como principais funções distinguir originais de apócrifos, recuperar textos transformados em palimpsestos, datar peças e estabelecer as variações redaccionais e editoriais de um dado texto. Pela sua particular importância destacamos a última destas funções.

Captar as variações de um texto e fixá-las numa edição crítica é proporcionar aos seus leitores a convivência com um texto em vias de constituição, com um texto vivo.

A partir de um tal ponto de vista, aparece como deslocada toda a questão a propósito da escolha do bom texto a partir das suas variantes. Relativamente a um texto de paleografia complexa, não existe o bom texto $\left({ }^{106}\right)$, mas sim um

(105) No sentido leibniziano do termo, cf. Louis Couturat, Opuscules et fragments inédits de Leibniz, Paris, Alcan, 1093, p. 531.

$\left(i^{\circ} 6\right)$ Anne Becco, provou recentemente a especificidade da edição de 1647. Cf. Anne, Becco, UIndex «substance» et le chemim du vrai selon Descartes. Étude des structures lexicales de Voeuvre métaphysique de Descartes appuyée sur l'opération informatique "Cogito 75». Thèse présentée à la Faculté de Lettres et Sciences Humaines de l'Université de Paris, sous la direction du professeur Yvon Bélaval, Paris, 1976, exemplar dactilografado, pp. 113-116. 
conjunto de variações que é necessário anotar. É assim que uma paleografia escrupulosa, adoptando um texto por base, revela pela sua anotação, simultaneamente a coerência e a heterogeneidade desse texto $\left({ }^{107}\right)$.

$\mathrm{E}$ assim que hoje os historiadores da filosofia continuam a estudar minuciosamente as variantes das seis edições que De la recherche de la Vérité de N. Malebranche conheceu entre $1674^{1}-1700^{\mathrm{G}}\left({ }^{108}\right)$. Essas variações que o autor introduziu à medida da evolução do seu pensamento, provocam em certas passagens inversão radicais em relação às disposições iniciais. Nestas variações, que são um relatório minucioso do pulsar de uma vida intelectual intensa inscrevem-se elementos capitais à compreensão do movimento das ideias no último quartel do século XVII $\left({ }^{109}\right)$. É nesta mesma ordem de ideias que devemos situar quer as divergências existentes entre a $1 .^{\mathrm{a}}$ e a $2 .^{\mathrm{a}}$ edição (respectivamente 1781 e 1787) da Crí-

(íoT) Todo o texto conhece tal flutuação. É assim que hoje, uma equipa constituída por Castelo Branco Chaves, Vitorino de Magalhães Godinho, Rui Grácio, Joel Serrão, Idalina Sá da Costa e Augusto Abelaira, se reuniu para notar as divergências verificadas entre $\mathbf{a}^{\wedge}$ pri- $^{\circ}$ meira e a segunda edição (1920 e 1949) dos Ensaios de António Sérgio. Tais cuidados são particularmente raros nas edições portuguesas. No caso de traduções verificam-se anomalias que podem ir até à modificação dos títulos das obras. Citemos a obra de Julia Kristeva recentemente publicada em português com o título História da linguagem. Nunca tal obra teve tal título. Da primeira à mais recente das suas edições ela aparece com o título Le langage, cet inconnu, Paris, S.G.P.P. col. «Le point de la question» $1969^{1}, 318$ p. e a edição mais recente ao título citado: Une introduction à la linguistique, Paris, Seuil, 1981, 327 p. Entre estas duas edições a grande modificação não se refere ao título mas sim ao nome da autora: de Julia Joyaux ela passou a apresentar-se como Julia Kristeva.

$\left({ }^{108}\right)$ Essas edições foram publicadas durante a vida do autor nos anos de $1674^{1} ; 1675^{2} ; 1678^{3} ; 1_{1678^{4}} ; 1683^{5} ; 1700^{6}$. De notar que algumas destas edições tiveram várias tiragens. De notar também algumas traduções inglesas e uma tradução holandesa da obra, todas durante a vida do seu autor. Em 1709, esta obra foi condenada e posta no índice.

Geneviève Rodis-Lewis, editou, introduziu e anotou três edições desta obra, respectivamente em 1946 (Vrin, 3 t.); 1962 (Vrin, 3 t., respectivamente t. I, II e III da edição das Oeuvres complètes, 20 t. de 1962-1964) e em 1979 para as edições Gallimard - N.R.F., Bibliothèque de la Pléiade. De notar que estas três edições anotam todas as variações constatadas entre as seis edições acima referidas. Entre cada uma das edições M. ${ }^{\text {me }}$ Rodis-Lewis reviu e aumentou consideravelmente o seu aparato crítico.

(109) André Robinet, Malebranche de VAcadérráe des Sciences. Uoeuvre scientifique, 1674-1715. Paris, J. Vrin/C.N.R.S., 1970, 448 p. 
tica da razão pura de Kant $\left({ }^{110}\right)$ assim como as divergências existentes entre os manuscritos de Hanover, Viena e Paris dos Principes de la nature et de la grâce e da Monadologie de Leibniz $\left({ }^{111}\right)$.

7.2.É sobre os textos assim estabelecidos por uma paleografia detalhada que se aplica a atenção artificial do au-

$\left({ }^{\text {no }}\right)$ M. Heidegger, aloja o seu comentário sobre Kant nesta diferença: cf. Kant et le probleme de la métaphysique, tr. fr. A. de Waelhens e W. Biemel, Gallimard, Paris, 1953 (ed. al. 1929) e Qu'est-qu'une chose?, tr. fr. Jean Reboul e Jacques Taminiaux, Paris, Gallimard, 1971 (sobretudo, pp. 67-250) (ed. al. 1962).

$\left.{ }^{\mathbf{m}}\right)$ Principes de la nature et de la grâce fondés en raison. Principes de la philosophie ou Monadologie. Publiés intégralement d'après les manuscrits de Hanovre, Vienne et Paris et présentés d'après des «lettres inédites» par André Robinet, Paris, P.U.F., 1954 ${ }^{1}$, 1978$^{2}$, 146 p. Existe uma tr. portuguesa da Monadologia do Discurso de metafísica e do primeiro livro dos Novos ensaios sobre o entendimento humano: as duas primeiras ed.s são uma trad, de António Novais Machado, Coimbra, Casa do Castelo, 1947, (edição não anotada), 121 p.; o preâmbulo e o primeiro livro dos Novos Ensaios, foram traduzidos e anotados por A. Sérgio.

Relativamente à edição de $\mathrm{A}$. Robinet, M. Heidegger pode escrever: «Il en est encore ainsi aujuord'hui, où nous pouvons suivre le mouvement et l'inquiétude de la pensée de Leibniz dans les manuscrits des deux ouvrages, manuscrits qui ne sont devenus accessibles que l'année dernière, grâce à la remarquable publication qu'en a fait André Robinet», Martins Heidegger, Le principe de raison, tr. fr. de André Préau, préf. de Jean Beaufret, Paris, Gallimard 1962, p. 117; (ed al. 1957).

Fixar um texto não significa de modo algum fechar a obra. Uma obra cujas variantes foram devidamente anotadas é uma obra aberta à investigação, e isso até aos fenómenos de serendipty como recentemente o lembrou o autor da Opera Aperta, "Jornal de letras», entrevista com Mário Fusco, ano II, n..$^{\circ}$ 41, p. 16; Umberto Eco, Opera Aperta, Milano, Bompiani, 1962, (tr. fr. 1965). Recentemente, U. Eco dedicou uma obra ao tratamento de alguns aspectos da abertura, mais precisamente às normas utilizadas pela comunidade abeceded. Entre esses dispositivos de abertura destaquemos a nota. Cf. U- Eco, Come si fa una tesi di laura, Milano, Bompiani, 1977, (existe tr. port. ed. Presença, $\mathbf{1 9 8 2}^{2}$ ). Recentemente, Jean Deprun lembrou numa nota: «Nous n'ignorons pas les inconvénients de cetce intervention d'éléments extérieurs à un propos dont ils rompent la continuité, mais il nous a paru impossible d'inviter sans cesse nos compagnons de route à entrependre, s'ils voulaient vérifier ou concrétiser nos dires, des recherches bibliographiques parfois délicates», Jean Deprun, La philosophie de Vinquiétude en France au XVIII ${ }^{e}$ siècle. Paris, J. Vrin, 1979, 454 p. (A anotação desta obra ocupa as pp. 217-449).

Assim, a anotação aparece definida por duas linhas de força: a) fornecer ao leitor o máximo de elementos histórico-críticos; b) tornar esses elementos verificáveis, aspecto marcadamente antidogmático 
tómato cibernético $\left({ }^{112}\right)$ : registando exaustivamente todas as variações diferenciais dos estratos constitutivos do texto, esta atenção dilatada revela de modo particularmente profundo e exacto a trama semiótica a partir da qual o texto se constitui. Produzindo um levantamento ordenado e medido, a atenção do autómato revela as disposições mais íntimas do vasto conjunto semiótico que serve de suporte ao texto filosófico.

Tais técnicas fornecem-nos assim índices sistemáticos do léxico, verdadeiros registos da vida molecular do texto e listas de concordâncias, diaposicionais e diacríticas $\left({ }^{113}\right)$ as quais constituem por seu lado o registo exaustivo da vida molar do texto. Este último tipo de concordâncias, sendo centradas sobre os vectores semióticos do texto permitem a detecção de estruturas características das articulações do discurso do autor, nomeadamente utilização de sintagmas, satelização de formas, fenómenos de vicariância e eclipses, totais ou parciais, de certas formas. Portanto, tais concordâncias constituem uma primeira aproximação rápida e exacta de alguns dos vectores semânticos do texto. De notar que esta transição do semiótico para o semântico é o resultado exclusivo da atenção consagrada às micro-estruturas lexicais, únicas a poderem revelar o nascimento e a implantação do sentido no texto.

Determinando plenamente os vectores lexicais de uma obra, a lexicografia informática delimita de modo preciso os campos de emergência do sentido. Assim, ela contribui para o estudo aprofundado, do texto ou do conjunto de textos aos quais ela se aplica. Quando o levantamento lexical é alargado à totalidade das obras de um autor $\left({ }^{114}\right)$, o conjunto obtido, quando devidamente diferenciado e datado, permite um estudo minucioso da evolução do seu pensamento.

e intimamente articulado com aspectos inerentes à sociologia do conhecimento. $A$ resultante das linhas anteriormente referidas poderia ser definido como um vector heurístico-prospectivo, vector que transporta a leitura na direcção do campo activo da produção.

${ }^{(112)}$ Sobre a mítica recusa do autómato por parte da filosofia cf. André Robinet, Le défi cybernétique; Vautomate et la pensée, Paris, Gallimard, - N.R.F., 1973, 230 p.

$\left({ }^{113}\right)$ Cf. André Robinet, Res, IIP Colloquio Internazionale do Lessico Intellettuale Europeu, Roma, Edizione delFAteneo, pp. 555-557.

$\left({ }^{114}\right) \mathbf{O}$ levantamento dos 20 volumes das Oeuvres complètes de Malebranche forneceu um thesaurus de mais de $\mathbf{2 . 0 0 0 . 0 0 0}$ palavras que actualmente começa a ser publicado. 
De realçar ainda que as concordâncias diacríticas colocam uma interrogação capital ao ser físico do livro $\left({ }^{115}\right)$ : as constelações recortadas na galáxia semiótica são de tal modo exaustivas que se torna materialmente impossível publicar a sua totalidade sob a forma de livro. Assim, as publicações onde tais concordâncias aparecem, na medida em que elas as não publicam integralmente, são geralmente classificadas como quasi-livros $\left({ }^{116}\right)$.

Instrumentos pré-hermenêuticos indispensáveis, os objectos produzidos por estas verdadeiras máquinas de leitura $\left({ }_{118}^{117}\right)$, dão a ver constelações imperceptíveis a olho desarmado (118). Podemos mesmo estabelecer uma analogia tirada da história da instrumentalização em astronomia que os estudos actualmente em curso confirmam amplamente: o autómato cibernético permite em relação ao texto algo de similar àquilo que a luneta astronómica no séc. XVI e o telescópio electronico

$\left.{ }^{115}\right)$ Cf. Paul Riesman, «De l'homme typograhique à l'homme électronique», Revue Critique, Editions de Minuit, 1966. Mc Luhan dedicou grande parte das suas publicações ao estudo desta questão. Retemos aqui The Gutenberg Galaxy: te making of typografic man. The university of Toronto press, Toronto, Canada, 1964, (tr. fr. 1967).

$\left.{ }^{116}\right)$ Os restantes dados ficam à disposição dos leitores nos laboratórios que os produzem. Tais laboratórios, na medida em que facilitam o acesso aos materiais que armazenam, devem ser considerados não como «bancos» de dados, mas sim como centros de distribuição de dados. Analogamente ao que aconteceu com a imagem relativamente à Enciclopédia de Diderot e d'Alembert, este novo aspecto do livro, integra-se naquilo que Roland Barthes designou como «une certaine philosopie de 1'objet», cf. Roland Barthes, arrigo «Image, raison, déraison", L'Univers de VEncyclopédie, images d'une civilisation. Paris, Les Libraires Associés, 1964, p. 11.

$\left.{ }^{117}\right)$ Cf. Yvon Beiaval, Etudes leibniziennes, Paris, Gallimard - N.R.F., 1976, pp. 381-384, capitulo com o titulo «Une machine à lire». Este capítulo é a reedição do prefácio a: Anne Becco, Du simple selon G. W. Leibniz, étude comparative critique des propriétés de la substance appuyée sur l'opération informatique "Monado 74». Paris. J. Vrin-C.N.R.S., 1975. 198 p. O prefácio de Y. Beiaval, pp. V-IX. O estudo de A. Becco tem por base os dados fornecidos por, Monado $\mathbf{7 4}, \mathbf{G}$. W. Leibniz, Discours de Métaphysique et Monadologie. Texte définitif avec indexation automatisée, tableau alphabétique des formes lexicales, tableau fréquentiel, concordances, tableau de co-occurrences, philogrammes. Sob a direcção de André Robinet e a colaboração de: A. Becco, M. Bastien, P. Clair, F. Ferrier, P. Lafon, M. Sekhraoui, Cl. Machgeels, P. Patesson e D. Pierre-Justin, Paris, J. Vrin-C.N.R.S., 1975, $140 \mathrm{p}$.

(118) Y. Beiaval foi o primeiro historiador da filosofia a comparar a aplicação da informática ao texto filosófico com a invenção do telescópio. Cf. Études, p. 382. 
no séc. XX permitiram em relação aos «mundos» dos corpos celestes $\left({ }^{119}\right)$.

7.3. Recusando as redundâncias da hermenêutica clássica a qual se abstém geralmente de reflectir os estratos paleográficos, os relevos lexicais e as disposições retórico-argumentativas dos textos, de que se ocupa, a lexicografia informática propõe uma suspensão, um retardamento na explosão do sentido, correlativos de uma maior atenção sobre o signo: atenção sobre os signos significa, em primeiro lugar, recusa das leis da semelhança e da generalização, globalmente inatentas em relação às diferenças internas inerentes a cada uma das obras de um autor e dos diferentes autores de uma mesma época $\left({ }^{12 \circ}\right)$; em segundo lugar, atenção semiótica, significa tomada em consideração da complexidade paleográfica e da diversidade lexicográfica, factores que, numa fase ulterior, tudo leva a considerar como elementos eurísticos e elementos de prova.

Constitui-se assim uma nova hermenêtica $\left({ }^{121}\right)$, que ao longo das suas múltiplas e minuciosas verificações textuais, fundamentalmente articuladas segundo as quatro disposicões fundamentais, constitutivas, da textura textual: paleográfica, lexicográfica, retórico-argumentativa e histórico-conceptual.

Centrada sobre o diferencial do signo e atenta às componentes históricas do sentido, a nova interpretação revela-nos dimensões do texto imperceptíveis aos métodos de interpretação clássicos.

7.4. Tal como relativamente à hermenêutica, a lexicografia estatístico-informática aparece em relação à história das ideias como um elemento capital do seu desenvolvimento.

Que o signo linguístico seja o suporte privilegiado da ideia todo o historiador o sabe $\left(^{\Gamma 22}\right)$. Dado que o texto, o documento, é o objecto privilegiado do historiador, a metodo-

$\left.{ }^{110}\right)$ Sobre esta questão será sempre interessante reler, Alexandre Koyré, Du monde clos à Vunivers infini, Paris, Gallimard, 1973 (l. ${ }^{\mathrm{a}}$ ed. americana, 1957; $l^{\mathrm{a}}{ }^{\mathrm{e}}$ ed. fr. 1962, P.U.F.).

$\left.{ }^{12 \circ}\right)$ Sobre periodização em história, cf. «La catégorie $\mathrm{XVII}^{\mathrm{e}}$ siècle: philosophie des sciences», Revue Internationale de philosophie, n. ${ }^{\circ} 114$, Bruxelles, 1975.

(1M) Designação que estabelecemos a partir do título da obra de Ch. Perelman e Olbrechts-Tyteca, Traité de Vargumentation, la nouvelle rhétorique, Paris, P.U.F., 2 vol. 1958, 734 p. (reeditado, Editions de l'Université de Bruxelles, $1970^{1}, 1076^{3}$ ).

(1M) Pelo menos depois de Giambatista Vico, ter publicado os seus Principi di Scienza Nuova, Napoli, 1744. 
logia de que nos ocupamos, porque fundamentalmente aplicada a textos, pode fomecer-lhe esse objecto sob a forma mais exaustiva, estável e fiável, isto é, quantificado e ordenado. Assim, sem ter que anticipar o seu trabalho de interpretação, o historiador das ideias dispõe de uma massa de informação que permitindo comparações e verificações consideráveis, transformam de modo radical o seu questionamento e reduzem ao mínimo conjecturas e generalizações.

No caso específico da história da filosofia, a nova metodologia tem incidências particularmente importantes tanto na arqueologia como no estabelecimento dos estratos de formação das obras de um autor ou de vários autores.

Correlativamente emerge uma história da filosofia arma$d a\left({ }^{123}\right)$ particularmente atenta à diferença. Alguns trabalhos recentes sobre Leibniz, Descartes e Espinoza confirmam esta íntima cooperação estabelecida entre lexicografia, hermenêutica e história da filosofia $\left({ }^{124}\right)$.

$C^{23}$ ) Podemos encontrar a expressão em muitas das obras e em alguns dos cinquenta artigos que 0 seu principal promotor lhe consagrou: cf. André Robinet, «Lexicographie philosophique et paléographie», Annali, Studi Filosofici, Napoli, Instituto Orientali di Napoli, p. 39-76 (a expressão re-aparece desde a p. 40). A última bibliografia exaustiva que conheço, e portanto largamente ultrapassada, foi publicada como suplemento à comunicação «L'informatique appliquée à l'oeuvre de Suárez», Cuadernos Salamantinos de Filosofia, VII, Salamanca, 1980, pp. 327-336 (a lista dos artigos que o autor consagrou a estas questões ocupam as pp. 334-336). Posteriormente foi publicado um importante artigo: "Criticai applications of philosophical lexicography: on the 'Profession de foi du Vicaire Savoyard'», Social Research, Summer, 1982, vol. 49, n. ${ }^{\circ}$ 2. Trata-se de um estudo sobre Ordre e Nature, feito a partir de Vicaire 76. J.-J. Rousseau, Profession de foi du Vicaire Savoyard, tableau alphabétique des formes lexicales, tableau frequentiel, concordances, co-occurrences, Paris, J. V rin - C.N.R.S., 1978.

(124) Além dos trabalhos de A. Becco já assinalados, (n. 106 e n. 117), devemos referir os de: Pierre-Alain Cahné, Un autre Descartes, le philosophe et son langage, Paris, J. Vrin, 1980, 324 p.; e o nosso estudo: Les significations du syntagme "lumière naturelle» dans les Méditations Métaphysiques de Descartes, estudo feito sob a direcção de André Robinet, Bruxelles, 1979-1980, tese dactilografada, 214 p. Este estudo, de que oportunamente será publicada uma síntese, tem como objecto a análise das treze ocorrências do sintagma «Lumière naturelle»); e sobre Espinosa 0 importante trabalho de Thierry Jadot, Les concepts fondamentaux de VEthique: Substantia «et» Modi. Le rapport Substance - Modes, Bruxelles, sob a direcção de A. Robinet, 1979-1980, tese dactilografada, 132 p. Trabalho apoiado em Ethica, concordances, index, listes de fréquences, tables comparatives. Publications du CETEDOC., Univ. Cath. de Louvain, 1977, par. M. Gueret, A. Robinet et P. Tombeur, XXI -538 p. 
7.5. Actualmente, as dificuldades inerentes à tradução $\left({ }^{125}\right)$ de um texto clássico polarizam-se em torno de dois pontos: a sua complexidade paleográfica e a vontade expressa de restituir de modo fiel o pensamento do seu autor.

Sobre o primeiro destes pontos, acabamos de fazer algumas considerações. Sobre o segundo, devemos notar que se desde longa data a questão da tradução tem sido objecto de diversas teorizações, o presente século, insistindo de modo particular sobre as relações estabelecidas entre pensamento e linguagem $\left({ }^{126}\right)$, contribuiu de modo decisivo à instauração de um horizonte de restituição integral do pensamento a partir de um minucioso trabalho de reconstituição da palavra e da letra $\left({ }^{127}\right)$.

Mesmo se em tal perspectiva o horizonte é fundamentalmente móvel, decididamente a tradução transformou-se por isso mesmo num empreendimento interdisciplinar que mobiliza competências várias que não sendo alheias às requeridas para uma fixação paleográfica se relacionam principalmente com a lexicografia e a filologia. Notemos ainda que relativamente aos problemas gerais da tradução, a tradução de obras filosóficas encontra as dificuldades inerentes a especificidade do léxico filosófico: extremamente pobre quanto à sua diversidade, ele é particularmente rico, sobredeterminado, relativamente ao sentido $\left.{ }^{128}\right)$. É o jogo constante de redefinições, conotações e denotações que solicita a maior parte da atenção dos tradutores.

$\left.{ }^{125}\right)$ Cf. Georges Mounin, Les problèmes de la traduction. Paris, Gallimard, 1963.

(12fl) Pensamos sobretudo na importância que a psicanálise de Freud a Lacan - atribuiu a essa relação. Marginalmente encontramos obras que relativamente à Idade Clássica são obras de referência: Ernst Cassirer, La philosophie des formes symboliques, t. 1, le langage, tr. fr. de Ole Hansen - Love et Jean Lacoste, Paris, Les Éditions de Minuit, 1972; Michel Foucault, Les mots et les choses, une archéologie des Sciences humaines, Paris, Gallimard - N.R.F., 1966, 398 p. (existe tr. port.); Noam Chomsky, Cartesian Linguistics: a chapter in the history of rationalist thought, New - York, Harper and Row, 1966 (existe tr. brasileira e fr.); Andre Robinet, Le langage à VAge Classique, Paris, ed. Klincksieck, 1978, 294 p.

\section{J. Derrida...}

$\left({ }^{m}\right)$ Pensemos no «objet petit a» de Lacan e a «diferance» de

${ }^{(128)}$ Mesmo no caso de Espinosa, autor que opera por definições, a explicitação das significações do seu léxico vão muito raramente além do substantivo. As definições dos adjectivos e dos verbos são raras. 
A recente tradução das Regulae ad directionem ingenii de Descartes $\left({ }^{129}\right)$, confirmou a importância da coordenação dos níveis paleográfico, informático-lexical, filológico e histórico, na execução de tal trabalho.

E assim que esta tradução toma como ponto de partida não só os resultados das investigações paleográficas de G. Crapuli, as quais estão na base da primeira edição crítica do texto das Regulae ${ }^{130}$ ), como o Índice lexicográfico realizado a partir da mesma edição ${ }^{131}$ ). Além dos cuidados de tradução que referiremos a seguir, notemos desde já que esta tradução, contendo um número muito importante de notas de carácter filológico, epistemológico e histórico é estabelecida segundo a intenção explícita de permitir «à d'autres de progresser» $\left({ }^{132}\right)$. É portanto, no intuito de fornecer aos leitores e investigadores um objecto de trabalho, que de modo algum dispensa a consulta dos originais latinos $\left({ }^{133}\right)$, que esta tra-

$\left.{ }^{\mathbf{1 2 9}}\right)$ René Descartes, Règles utiles et claires pour la direction de Vesprit en la recherche de la vérité, tr. selon le lexique cartésien et annotation conceptuelle par J.-L. Marion, avec des notes mathématiques de P. Costabel, La Haye, Martinus Nijhoff - C.N.R.S., 1977, 347 p. (existe tr. portuguesa, Regras para a direcção do espírito, tr. A. Reis, ed. Estampa, $1977^{2}, 130$ p. e uma página de notas).

(130) René Descartes, Regulaë ad directionem ingenii, texte critique établit par Giovanni Crapulli avec la version hollandaise du $\mathbf{X V I I}^{\mathrm{e}}$ siècle, Archives Internationales d'Histoire des Idées, 12, La Haye, 1966. A versão holandesa é a estabelecida por J. H. Glazemaker, publicada em 1684, no tomo III dos R. Descartes Brieven, Amsterdam, J. Rieuwertz. O original latino desta obra só foi editado em 1701, in Opuscula posthuma physica et mathematica de Descartes, P. et J. Blaeu, Amsterdam. A edição A.T. X. 285-324, segue a cópia de Leibniz- que hoje se encontra na Landesbibliothek de Hanover - cópia anotada por Leibniz, e a edição de 1701. A edição Crapulli segue a ed. flamenga de 1684; a edição latina de 1701; 0 manuscrito de Hanover considerando-o no seu estado primitivo, e tendo em conta as correcções e anotações de Leibniz. Notemos que A.T. não só muitas vezes não distingue as intervenções de Leibniz, como não utiliza a edição de 1684. Sobre estas questões, G. Crapulli, explica-se amplamente em: "Note alTedizione critica di Adam - Tannery delle 'Regulae ad directionem ingenij' di Descartes», Rivista critica di storia della filosofia, XIX, 1964, I, pp. 54-61.

( $\left.{ }^{131}\right)$ René Descartes, Index des Regulae ad directionem ingenii, par J.-R. Armogathe e J.-L. Marion, avec des listes de leçons et conjectures établies par G. Crapulli, Roma, Edizioni delTAteneo, 1976. Existe igualmente um Index du Discours de la méthode, par Pierre - Alain Cahné, Roma, Centro di Studio del C.N.R., ed. dell'Ateneo, $1977,90 \mathrm{p}$.

$\left.{ }^{132}\right)$ Ob. cit., p. V.

(133) Como se deve, a edição Marion - Costabel, reproduz em margem a paginação do tomo $X$, da ed. A.T., e isso, mesmo se ela não segue estritamente o texto latino publicado por A.T. 
dução anota detalhadamente todas as dificuldades que o texto apresenta.

Para além da filosofia inerente a essa preciosa anotação, a tradução mostra-se particularmente atenta a outros problemas. Denunciando e repudiando todas as deformações praticadas no texto quer para o clarificar, quer para o tornar mais acessível $\left({ }^{134}\right)$, esta tradução, que não foi feita na perspectiva da passagem de uma língua morta a uma língua viva, tem como objectivo pôr à disposição de um vasto público uma versão francesa das Regulae.

Tais opções, aparecem portanto como uma recusa do erro mais grave e mais frequentemente cometido na tradução de textos clássicos, a saber, a prática voluntária ou involuntária de anacronismos inerentes à atribuição ao autor de termos que veiculam conceitos que nem o seu léxico nem o seu pensamento comportam. Tais práticas, contrariam os princípios mais elementares da filologia e da história das ideias.

Estas decisões tomadas, o tradutor coloca a importante questão de saber êm qual das linguagens da língua receptora, traduzir a obra. É pelo seu contributo à resposta a uma tal questão que a estatística lexical revela a sua importância capital.

Os Índices disponíveis (os editados e os disponíveis em laboratório), permitem não só uma apreciação global sobre cada um dos grandes conjuntos do léxico do autor, o conjunto lexical latino e o conjunto lexical francês, mas permitem igualmente destacar nesses blocos as camadas relativas à epistemologia, à metafísica, à moral e à teologia. Assim, o tradutor, reconhecendo a especificidade de cada um destes blocos e datando minuciosamente cada uma das suas camadas, isolou o léxico epistemológico anterior a 1637, (mais precisamente, aquele que o autor utiliza até à publicação dos Ensaios científicos que acompanhavam o Discurso do método $\left({ }^{135}\right)$, léxico do qual se serviu exclusivamente na sua tradução. Capital foi igualmente a explicitação dos princípios se-

${ }^{(134)}$ Tal é, a opção de A. Sérgio ao traduzir as Meditationes/ IMéditations: «Buscámos que a versão presente fosse a mais clara e o mais fácil possível para o leitor moderno", cf. ob. cit., p. 133. O sublinhado é nosso. Sobre esta questão, ver parte III, 3. e n. 185.

$\left.{ }^{135}\right)$ O título completo da obra é significativo: Discours de la méthode, pour bien conduire sa raison, et chercher la vérité dans les sciences. Plus la Dioptrique. Les Météores et la Géométrie. "Qui sont des essais de cette méthode». 
guidos na tradução. Eles resumem-se a três: a) princípio de correspondência, segundo o qual a um termo ou locução da matriz deve corresponder na tradução um só termo ou locução; b) princípio de coerência, segundo o qual o mesmo termo ou locução latinos são traduzidos sempre do mesmo modo; c) prinçípio de ordem, que consiste em seguir a sintaxe da frase latina. Este princípio conduz o tradutor a conservar as particularidades da pontuação do autor ( $\left.{ }^{136}\right)$.

Ao estabelecer como horizonte da sua tradução o decalque, tão exacto quanto possível do léxico e da estrutura da frase latina, o tradutor assume explicitamente $\left({ }^{137}\right)$ o sar crifício que daí resulta relativamente à estética do texto. A sua principal preocupação é a de restituir o pensamento do autor a partir do seu próprio léxico.

\section{DIAGRAMA I: EDIÇÕES DAS MEDITATIONES}

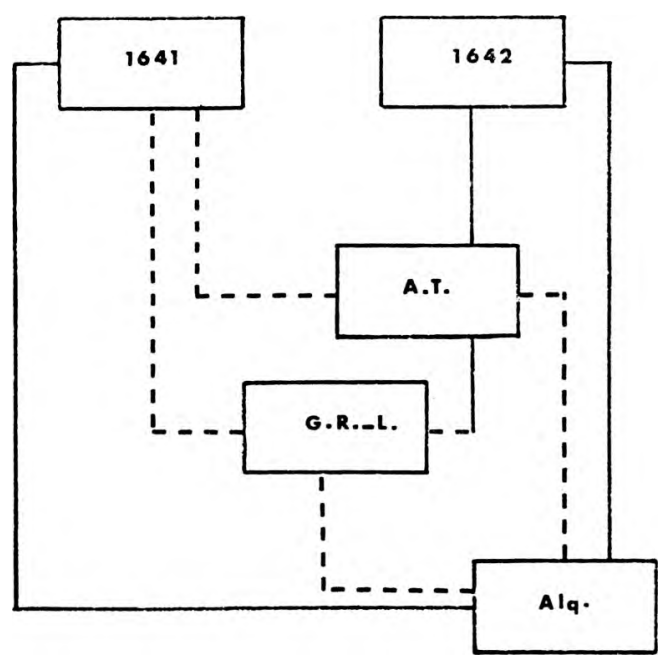

$\left({ }^{13 f 1}\right)$ Cf. ob. cit., p. XI.

(13T) «Il va sans dire que le souci d'élégance, voir même d'intelligibilité claire et évidente, reste au second rang, surtout s'il devait contredire aux principes énoncés plus haut», ob. cit. ${ }_{y}$ p. XII. 


\section{Antonio Sérgio}

DIAGRAMA II: EDIÇÕES DAS MÉDITATIONS

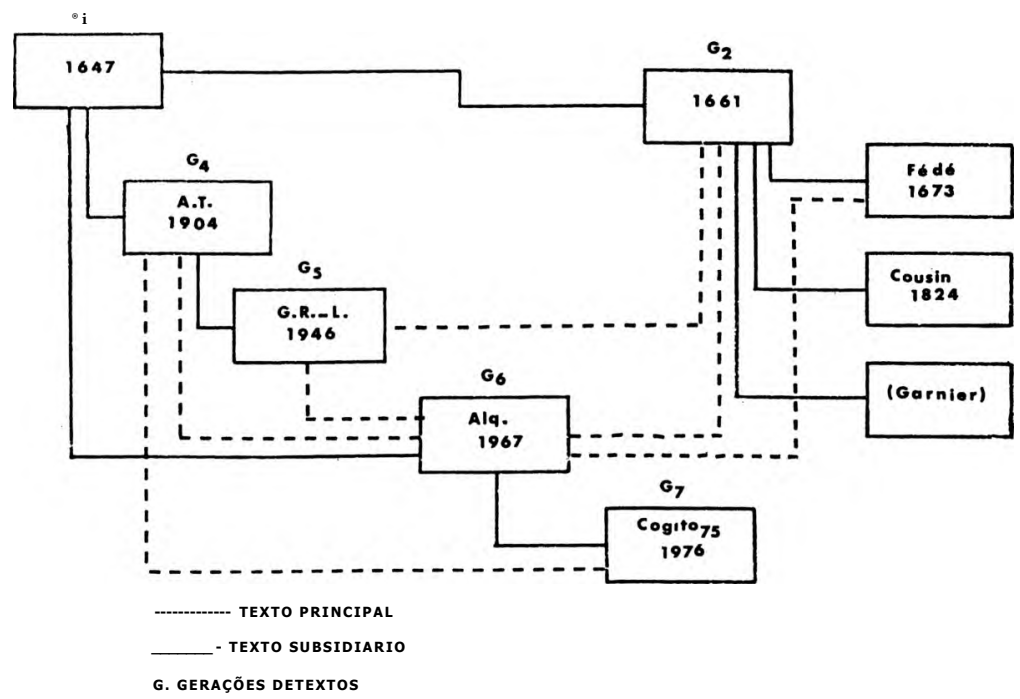

II

1.1. A tradução de António Sérgio de que nos ocupamos aqui, saiu a público com o seguinte título:

RENATO DESCARTES | MEDITAÇÕES | METAFÍSICAS | ! TRADUZIDAS POR ANTÓNIO SÉRGIO | COIMBRA | IMPRENSA DA UNIVERSIDADE | 1930.

1.2. A obra é apresentada com as seguintes peças $\left({ }^{18 \mathrm{~S}}\right)$ : a) Epístola ao Decano e Doutores da Faculdade de Teologia de Paris; b) Prefácio ao leitor; c) Meditações Metafísicas. Resumo das seis meditações seguintes; d) seguem-se as seis meditações; e) uma Nota do tradutor; f) e o volume termina com um Índice $\left({ }^{139}\right)$.

('“) Para não sobrecarregar a tipografia, a nossa enumeração afasta-se da tipografia original.

$(\mathrm{H} ») \quad \mathbf{p}_{\epsilon} \boldsymbol{c}_{\text {as }} \mathbf{q}_{\mathrm{Ue}}$ ocupam respectivamente as páginas: a) pp. $\mathrm{V}$ XI; b) pp. XIII-XVII; c) pp. 1-7; d) pp. 9-129; e) pp. 133-136; f) p. 137 . 
2.1. Variações de títulos e de peças na tradução portuguesa.

Quando a tradução portuguesa se limita a adoptar como título a designação cursiva de Meditações metafísicas, não só ela oculta ao leitor os títulos das sucessivas edições princeps mas também, e consequentemente, ela omite elementos capitais da história do texto, nomeadamente a importante divergência existente entre os títulos da primeira e segunda edições latinas $\left({ }^{140}\right)$.

2.2. As principais variações registadas são as seguintes:

a) sob o título: EPÍSTOLA | AO DECANO E DOUTORES | i DA FACULDADE DE TEOLOGIA DE PARIS, é traduzida uma peça que só existe nas primeiras edições latina e francesa, e nos dois casos com títulos diferentes daquele que a edição portuguesa apresenta $\left({ }^{141}\right)$;

b) é omitida uma peça, inexistente nas edições latinas, mas que aparece na edição francesa sob o título, LE LIBRAIRE AU LECTEUR, para substituir o PRAEFATIO AD LECTOREM das edições latinas $\left({ }^{142}\right)$;

c) são igualmente omitidas todas as referências às restantes peças que constituem as edições de 1641, 1642 e 1647, assim como à sua posição nessas edições;

d) por fim, em relação aos textos de referência, a edição portuguesa apresenta dois tipos de parasitagem: um devido à adição de títulos à Synopsis/Abregé, o outro que consiste em introduzir antes de cada uma das meditações, um resumo que não só repete a função da Synopsis/Abregé, mas também interrompendo a sequência pópria da obra, interfere no seu conteúdo $\left({ }^{143}\right)$.

3. Variações de signos e de regras.

\subsection{Ortografia}

$\mathrm{Na}$ tradução portuguesa registamos variações de ortografia que pelas suas incidências semânticas merecem ser notadas.

(40) Cf. I. 1.1. e I. 1.2.; I. 21. e I. 2.2.; I. 3.1. e I. 3.2.; e de I 4.1. a ${ }_{(141)}^{1.42}$.

(143)

1.3.; I. 3.3. aos resumos acrescentados.

Cf. I. 1.3.; I. 2.3.; I. 3.3.

Na Correspondência, não encontramos nenhuma alusão 
Assim, enquanto Descartes utiliza geralmente os caracteres maiúsculos para ortografar o nome das disciplinas a que se refere, a tradução portuguesa utiliza de modo preferencial as minúsculas: Aritmétique e Geometrie (5.46.11; 5.46 .12 ; 5.49.37) $\left.{ }^{144}\right)$, aparecem impressos respectivamente como aritmética e geometria (S.89.07; ib.). Todavia, de tal divergência não podemos concluir que o tradutor tenha estabelecido uma regra, pois, por exemplo, Geometria aparece por vezes na tradução portuguesa (S.IX.23) $\left({ }^{145}\right)$.

Variações idênticas ocorrem igualmente a propósito de outras formas, por exemplo, quando Descartes imprime sucessivamente nature e Nature $(5.49 .38 ; 5.49 .44)\left({ }^{146}\right)$ o tradutor restitui indistintamente natureza (S.95.17; 95.26). A propósito desta última divergência, e porque a forma Nature aparece no texto latino de 1642 impresso em caracteres minúsculos, seriamos tentados a concluir que o tradutor teria adoptado como base da sua tradução o texto latino. Todavia, outras razões obrigam-nos a pensar o contrário.

Similares são as variações que indistintamente afectam títulos de obras - Discours ( ${ }^{14}$ ) é ortografado, discurso (S.XIII.3) - designações - Philosophes Chrétiens $\left({ }^{14 S}\right)$, filósofos cristãos (S.VII.12), Infidèles $\left({ }^{149}\right)$, infiéis (S.V.17), - e nomes Cercle e Ame $\left({ }^{150}\right)$ aparecem ortografados, círculo e alma (S.VI.11; VII.6).

\subsection{Pontuação}

Considerando as diferenças específicas das sintaxes e das morfologias latina e francesa, e porque traduzir não é necessariamente, nem transpor nem trair, somos conduzidos a notar como prejudiciais as frequentes alterações de pontuação praticadas pela tradução portuguesa.

De um modo geral, podemos dizer que a maior parte de tais modificações se destinam a encurtar as frases que em Descartes - independentemente da língua na qual ele se ex-

\footnotetext{
$\left({ }^{144}\right)$ A.T. IX. 52; VII. 65.

(145) A.T. IX. 7; VII. 4.

(14C) A.T. IX. 55; VII. 9, 70 (naturâ).

(14T) A.T.VII. 7.

(148) A.T. IX. 5; VII. 3.

(149) A.T. IX. 5; VII. 2 (infidelibus).

(,6) A.T. IX. 5; VII. 2 (circulum;animam).
} 
prime - tendem a ser invariavelmente longas ( ${ }^{151}$ ). Tais modificações, com imediatas incidências estilísticas e conceptuais, ocultam-nos dimensões do texto que actualmente interessam um número crescente de investigadores $\left({ }^{152}\right)$.

Os referidos cortes de frase aparecem por exemplo um grande número de vezes na vizinhança imediata da locução conjuntiva c'est-à-dire. Muitas vezes, a ocorrência de tal locução é ocasião não só de um corte na frase, mas também da supressão dessa locução $\left({ }^{153}\right)$.

Todavia, o que acaba de ser notado não aparece como um processo que pela sua frequência de repetição nos leva-

${ }^{(181)}$ Tais disposições, Descartes podia encontrá-las igualmente na obra que um filósofo-médico, português de nascimento, publicou em Lyon em 1581 sob o título: De multum nobili et prima universali scientia, quod nihil scitur. Nesta obra, tal era o encadeamento dos protestos do seu autor contra o falso saber escolástico que nas 100 páginas in $4 .^{\circ}$ ele não fez um único parágrafo.

A extensa bibliografia dos estudos consagrados a F. Sanches é em grande parte dedicada à sua hipotética influência sobre Descartes. (Notemos que entre esses estudos não conhecemos nenhum consagrado à posição de $F$. Sanches nas obras de Gassendi e de Leibniz. Com efeito tanto um como o outro o referem: a) Gassendi nas Exercitationes Paradoxicae Adversus Aristoteleus, de 1649, quando no libro II o autor escreve: "Hic est ubi praeceipua jaciuntur Pyrrhonismi fundamenta, stabiliturque maxime illud, Nihil sciri». B. Rochot na sua sábia edição bilingue da obra de Gassendi anotou a influência, cf. Dissertations en forme de paradoxes contre les aristotéliciens, Paris, J. Vrin - C.N.R.S., 1959, pp. 12-13, n. 18; b) Uma das referências que Leibniz faz a Sanches é a seguinte. «J'ai souvent considéré qu'un géomètre, qui répondrait aux objections de Sextus Empiricus et à celles de François Suarez, auteur du livre Quod nihil scitur...» in carta a Varignon, 2 février, 1702, Mathematische Schriften, ed. Gerhardt. Por erro de leitura ou de impressão, Gerhardt fez imprimir Suarez, quando Leibniz tinha escrito Sanchez. Foi André Robinet que recentemente, após uma verificação de ortografia nos Briefwechsel Varignon, $\mathrm{L} B r$. foi. 5 v., pode corrigir tal anomalia, modificando assim o estado da questão relativa à influência do pensamento de Suarez sobre Leibniz, cf. André Robinet, «Suarez dans l'oeuvre de Leibniz», Cuadernos Salamantinos de Filosofia, VII, Salamanca 1980-1981, pp. 191-209).

(**) Pierre-Alain Chané, Un autre Descartes, ob. cit., 1980. Neste estudo, a obra de Descartes é analisada do ponto de vista estilístico.

${ }^{163}$ ) Cogito 75, fornece-nos dados detalhados sobre a alocução c'est-à-dire, cf. pp. 73 e 116). Ela ocorre 55 vezes e tem a seguinte distribuição: $M_{0}: 4 ;$ Mi: $0 ; M_{2}: 5 ; M_{3}: 21 ; M<: 10 ; M_{5}: 7 ;$ Ma: 8. Sendo a 82. ${ }^{a}$ forma relativamente ao conjunto das formas dô léxico desta obra, ela ocupa relativamente às formas lexicalizadas a $13 .^{\mathrm{a}}$ posição.

Na tradução portuguesa ela aparece: a) quarenta $e$ duas vezes traduzida pela expressão isto é; b) uma vez traduzida por outrossim (S.64.02; 3.33.11); c) três vezes traduzida por quer dizer (S.55.23; 67.10.; 73.15-16; texto fr. $3.28 .21 ; 3.34 .38 ; 4.38 .02)$. A tradução omite cinco 
ria a considerá-lo como uma regra, pois, em certos casos a locução mantém-se sendo intercalada entre dois sinais de dois pontos: assim, por exemplo a frase, «nous pouvons faire une chose, ou ne la faire pas (c'est-à-dire affirmer ou nier, poursuivre ou fuir), plutôt seulement en ce que....» $(4.40 .07 .09)\left({ }^{154}\right)$, é traduzida do seguinte modo: «podemos fazer, ou não fazer, uma mesma cousa: isto é: afirmai* ou negar, buscar ou evitar, uma mesma cousa» (S.77.11-14). Notemos ainda que na frase traduzida, podemos assistir a um eclipse total, a uma verdadeira ocultação, dos parênteses da frase original.

Como último aspecto das modificações introduzidas pela tradução portuguesa notaremos o importante número de parágrafos que ela introduz. Se os textos originais de Descartes apresentam o inconveniente de só apresentarem parágrafos nas duas últimas meditações tal facto não é alheio às disposições conceptuais inerentes ao propósito meaitativo do autor. Uma passagem do texto incita-nos a manter o nosso ponto de vista. Na sua única ocorrência do texto francês $\left({ }^{155}\right)$, o termo interrompre aparece referido a ordem e a meditar: "sans interrompre l'ordre du méditer» (3.22.18), frase que tudo leva a interpretar no plano do conceito, como uma recusa de mediação, e no plano da metodologia como uma adopção de um modelo geométrico. Notemos ainda que os planos conceptuais e metodológico se encontram amplamente confirmados pelos planos arquitectónico e lexicográfico.

vezes a expressão, respectivamente em: $3.33 .45 ; 3.34 .01 ; 3.34 .24 ; 5.49 .10$; 5.56.35, que deveriam aparecer em S.65.23; 66.02; 66.25; 94.19; 111.12.

Dadas as disposições internas desta obra, e o paradigma, que ela veicula, um racionalismo em vias de geometrização, apresenta-se-nos como capital interrogar as suas estruturas mais finas. Sem nos determos sobre as nossas dúvidas em relação ao suplemento de voluntarismo que a expressão portuguesa, quer dizer, acrescenta à locução, c'est-à-dire, (assim como ao hoc est latino...) a questão que colocaríamos seria a seguinte: qual a significação da expressão, quer dizer, quando considerada no interior de um dispositivo que nas suas articulações conceptuais, retórico-argumentativas e lexicais, se pensa, se distribui e se exprime segundo a exigência metodológica da clareza e distinção. Recentemente A. Robinet analisou as disposições de hoc est no interior da Ética, e de vei no enunciado latino do cogito, ef. Ethica 77, concordances, Index etc. Louvain-La-Neuve, Presses du CETEDOC, 1977, pp. 525-538, e, Le langage à VAge classique, Paris, ed ${ }^{\mathrm{s}}$ Klincksieck, 1978, pp. 99-133.

$\left({ }^{1 M}\right)$ A.T. IX. 46; VII. 57.

(155) ${ }_{A T}$. IX. 29 (frase acrescentada pela edição francesa). 


\subsection{Travessões}

Este signo, normalmente utilizado para diferenciar os interlocutores de um diálogo, indicar uma suspensão no discurso e separar palavras ou preposições do seu contexto geral, é preferencialmente introduzido na tradução para preceder a alocução quer dizer, uma das versões que a tradução portuguesa reserva à expressão francesa, c'est-à-dire. Assim, as frases, «procèdent du néant, c'est-à-dire qu'elles ne sont en moi....», «que je désire, c'est-à-dire qu'il manque» e «beaucoup plus dificile, que moi, c'est-à-dire une chose ou une substance qui pense» (3.28.21-22; 3.29.38; 3.31.41-42) $\left({ }^{156}\right)$, frases traduzidas respectivamente por: "puro nada, - quer dizer, que só....», «que desejo, — isto é que me falta....» e enfim, "contrário, que eu — isto é: cousa pensante....» (S.55.23; 58.01; 61.25) $\left({ }^{157}\right)$.

\subsection{Itálicos}

Podem igualmente verificar-se na tradução portuguesa importantes modificações relativamente à utilização dos caracteres itálicos. Se ela introduz itálicos, por vezes ela suprime os itálicos originais.

Assim, a frase une chose qui pense $(2.14 .8 ; 2.15 .6)\left({ }^{158}\right)$, é sucessivamente traduzida: «Uma cousa que pensa». e "Uma cousa pensante», $(\mathrm{S} .27 .08 ; 29.01)\left({ }^{159}\right)$. Notemos aindà que são acrescentados itálicos, por exemplo aos termos voyons e jugeons $(2.17 .39 ; 2.17 .40)$ que aparecem portanto impressos respectivamente VEMOS e AJUIZAMOS, (S.34.08; 34.10).

Por fim, notemos ainda que aspas, signos tipográficos que Guillaume ainda não tinha inventado no momento das três primeiras edições da obra $\left({ }^{160}\right)$, aparecem por vezes para substituir os itálicos originais e mesmo como adjuvantes dos mesmos. É o caso de IDEE e seulement $\left({ }^{161}\right)$ termos que aparecem impressos: «idea», e, «SOMENTE» (S.XIV.28; XIV.08.

$\left({ }^{156}\right)$ A.T. IX. 35, 36, 38; VII. 44, 45, 48.

$\left({ }^{157}\right)$ A.T. IX. 21, 22; VII. 27, 28.

(158) A.T. VII. 28 (Res cogitans).

(ce) A.T. IX. 25; VII. 32.

(160) A aparição das aspas data somente de 1677.

(161) Dado que a peça de onde provêm estas duas ocorrências não foi traduzida na edição de 1647 , utilizaremos as suas traduções, feitas por Clerselier na sua edição de 1661 , cf. G. R.-L., p. 7. No texto latino $T A N T U M$ aparece impresso em caracteres itálicos e ideam em caracteres normais, cf. A.T. VII. 8. 


\section{Antonio Sérgio}

\subsection{Aspas}

Sendo relativamente aos textos de Descartes, absolutamente «imaginárias» $\left({ }^{162}\right)$, elas são frequentemente utilizadas pelo tradutor. Notemos algumas dessas utilizações: nature, (3.23.47; 6.59.35 $\left({ }^{163}\right)$, termo que aparece transformado em «natureza» (S.47.15; 117.04). Parasitagem idêntica acontece com sens comum, (2.18.10) $\left({ }^{164}\right)$, expressão restituída por "senso comum», (S.35.02).

\subsection{Parênteses}

De notar ainda a discordância existente entre a utilização de parênteses no texto francês e na tradução portuguesa.

Contamos entre os parênteses omitidos aqueles que acompanham a expressão (pour ainsi parler), (3.25.15 (165) que desaparecem na tradução: por assim dizer, (S.50.06). Como parênteses adicionados notemos os que acompanham a frase: (isto é: partidparão.... ou de perfeição), (S.50.07-08), tradução de: cest-à-dire participent...., $(3.25 .15-16)\left({ }^{166}\right)\left({ }^{167}\right)$.

4. Comparação lexicográfica das ocorrências de raison e raisons com as ocorrências de razão e razões na tradução portuguesa.

4.1. Os termos raison e raisons apresentam na obra de Descartes de 1647 distribuições distintas que quando confrontadas com as da sua tradução portuguesa revelam divergências consideráveis entre os dois textos.

Tais divergências, facilmente quantificáveis podem ser apresentadas sob a forma de um quadro que tem a vantagem de permitir uma apreciação global das disposições quantitativas e retóricoargumentativas dos dois textos.

$\left.{ }^{162}\right) \quad$ Por analogia com o «problema intrincado, imaginário talvez, mas muito interessante», A. Sérgio, MM, Nota do tradutor, p. 135.

C $^{163}$ ) A.T. IX. 30, 65; VII. 38, 82.

(104) A T IX 25* VII 32 ita loquar».

(H*) A.'L IX. 32; VII. 40. Ò texto latino diz somente: «atque, ut

(i«ii) A .T. IX. 32; VII. 40, (frase que não existe no texto latino).

(IfIT) Nota sobre a paginação da tradução portuguesa. Não nos aparecem de modo claro as razões pelas quais essa edição utiliza numeração romana nas páginas que precedem o resumo, fazendo assim pensar que tal numeraçã̃o é homóloga daquela que se encontra nas edições princeps... 


\begin{tabular}{|c|c|c|c|c|c|c|c|c|}
\hline & Totais & 0 & I & II & III & IV & V & VI \\
\hline raison & 34 & 1 & 3 & 3 & 8 & 10 & 1 & 8 \\
\hline razão & 24 & 1 & 4 & 1 & 5 & 5 & 1 & 7 \\
\hline raisons & 24 & 4 & $2^{\prime}$ & 2 & 5 & 1 & 6 & 4 \\
\hline razões & 24 & 3 & 1 & 2 & 5 & 1 & 5 & 5 \\
\hline
\end{tabular}

4.2. As divergências que o quadro anterior permite avaliar têm as seguintes traduções gráficas:

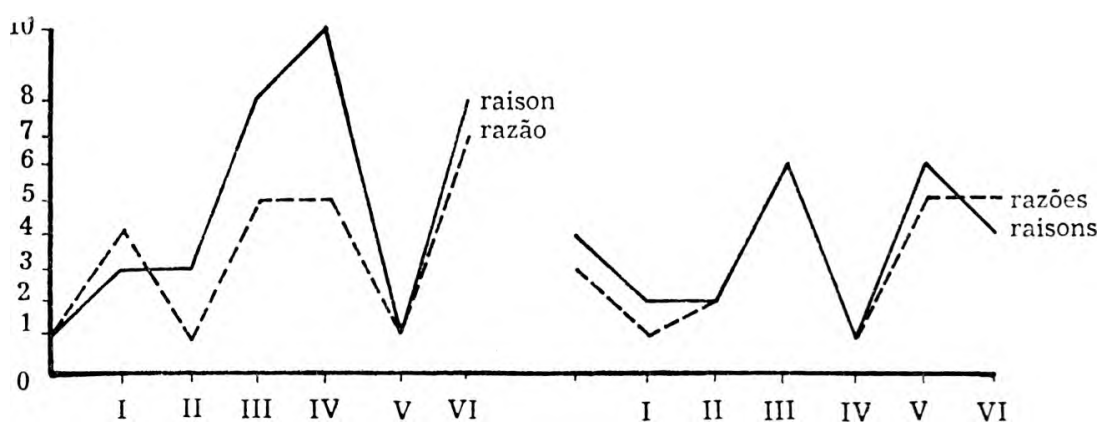

4.3. Em relação às divergências patentes nos gráficos e no quadro de ocorrências, devemos notar que a quantificação do léxico razão, razões da tradução portuguesa, porque feita em números absolutos oculta as numerosas omissões, adições e formas vicariantes dessa tradução.

Todavia, o carácter aproximativo de tais gráficos pode ser rectifiçado por uma comparação local dos dois textos: ela revelará pela emergência de discordâncias-distorções introdutoras de formas vicariantes assim como pelas suas numerosas adições e omissões a flutuação da tradução portuguesa em relação ao texto francês.

\subsection{Omissões $\left({ }^{168}\right)$ \\ 0.03.24 : en quoi consiste la raison de l'erreur \\ S.5.23 : se explica a natureza do erro}

$\left.{ }^{168}\right)$ Referências na ed. A.T. das omissões de raison: A.T. IX. 11, $22(2 x), 28,35,38,44(2 x), 45,45-46,59$. 


\section{Antonio Sérgio}

2.14.32 ni par conséquent, et à plus forte raison

S.28.05 por consequência, não está dependente de nenhuma das cousas

2.14 .43

S. 28.16

j'aurais aussi peu de raison en disant que seria tão pouco razoável dizer

3.21 .36

S.43.14

ce n'a point été pour autre raison

foi só porque

3.28 .27

je ne vois point de raison pourquoi

3.31 .21

S.61.03 e não vejo pois por que motivo

4.38.23

S.74.09

ne se ressouvient pas facilement de la raison já se não recorda com facilidade porque é que

4.38 .31 je n'ai aucune raison de douter e que não devo duvidar

S.74.17

Et cette seule raison

4.39.20

S.75.28 e isto basta para

il n'y a aucune raison

pois nada, em suma

4.40.01 : soit à raison de la connaissance et

S.77.05 : quer pelo saber e

4.40.03 : soit à raison de l'objet

S.77.07 : quer pelo objecto

6.54.04 : ce n'était pas sans raison

S.106.10-11 : razões tinha que me levavam a crer

\subsection{Vicariâncias}

O exame atento das omissões de tradução de raison, revela a emergência de termos que na tradução portuguesa tendem a funcionar como seus vicariantes. Esses termos são natureza, razoável e razões, termos que retrovertidos podem ser encontrados no léxico do autor. Assim, nature, raisonnable e raisons, ocorrem nesta obra de Descartes respectivamente: 115,5 e 24 vezes. Uma elementar constatação destes perfis permitem-nos avaliar a sua disparidade em relação ao número total das ocorrências de raison e portanto concluir a sua inaptidão a uma tal vicariância. 


\subsection{Adições $\left({ }^{169}\right)$}

As ocorrências da forma razão introduzidas pela tradução portuguesa repartem-se segundo dois grupos respectivamente, os resumos acrescentados pelo tradutor antes de cada meditação e o grupo formado pelo Resumo e pelo texto da primeira meditação. Essas adições são as seguintes:

5.40 .23 : Primeira razão

5.40 .24 : Segunda razão

S.69.07 : Que assim, bem usando da razão

5.85.14 : Razão que me parece provar

5.85.15 : Que esta razão é um puro sofisma

5.6.15 : uma nova razão, na qual, no entanto

0.03.37 : démonstrée par de nouvelles raisons, dans lesquelles

S.11.09-10 : qualquer razão de a por em dúvida

1.06.12 : le moindre sujet de douter

4.7. O estudo local da tradução portuguesa da forma raison, revelou-nos dados susceptlveis de corrigir o perfil global apresentado no gráfico I. Estabelecemos assim um novo gráfico, complementar do precedente onde são assinaladas, relativamente ao texto francês, omissões e adições.

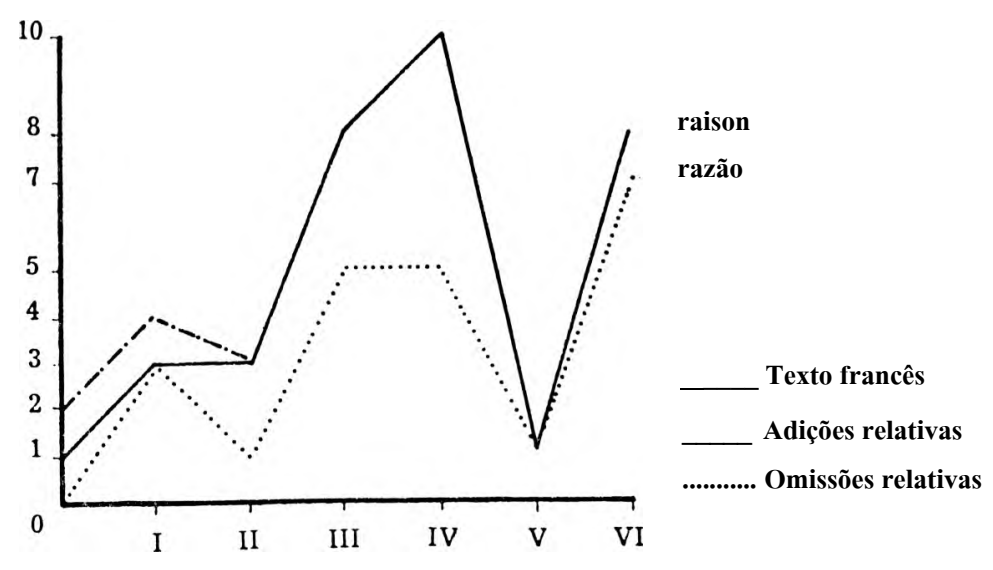

$14,11$.

$\left.{ }^{16{ }^{\prime \prime}}\right)$ Referências na ed. A.T. das adições de razão: A.T. IX. 


\section{Antonio Sérgio}

4.8. Por seu lado, a forma raisons, uma das três vicariantes da forma raison, apresenta na tradução portuguesa as seguintes flutuações:

4.8.1. Omissões $\left({ }^{17 \circ}\right)$

0.03.37 : démontrēē par de nouvelles raisons

S.6.15 : por uma nova razão

1.09.12 : mais pour des raisons très fortes

S.16.19 : mas por motivos mais fortes

3.33.07 : il s'ensuit, par les raisons que

S.64.08 : pelos motivos que aleguei há pouco

5.50.26 : porté à les croire par des raisons que

S.97.02 : acreditar nelas pelos motivos que

\subsubsection{Vicariâncias}

Razão e motivos são as formas que na tradução portuguesa tendem a substituir raisons. Como já podemos verificar, raison, quer pelo seu número de ocorrências quer pela distribuição das mesmas na arquitectónica da obra aparece nesta de um modo distinto de raisons. Quanto a motifs, retroversão de motivos, trata-se de uma forma sem ocorrências no texto de 1647 .

\subsubsection{Adições}

$\mathrm{Na}$ tradução portuguesa, verifica-se igualmente uma distorsão originada pela aparição de seis ocorrências da forma razões nos resumos-tópicos que precedem o texto das meditações e uma ocorrência de tal forma no texto da terceira meditação. Essas ocorrências são as seguintes:

5.9.18 : Que razões nos podem, apesar disso

5.39 .18 : Duas razões que nos persuadiram

S.39.20 : Que a primeira destas razões não é convincente ${ }^{11}$

$11,17,39,56$.

$\left({ }^{17 \circ}\right)$ Referências na ed. A.T. das omissões de raisons: A.T. IX. 
S.40.21 faz que esqueçamos facilmente as razões desta verdade.

S.99.23 Duas razões gerais

S.99.25 seria fácil responder às razões que nos persuadiram

S.44.09 considerei ainda as razões que demonstram

3.22.09 ${ }^{171}$ ) pas encore considéré celles qui prouvent

4.8.4. O cotejo do texto francês com o texto português revela-nos que relativamente a raisons e razões, há como no caso das formas raison e razão, divergências consideráveis entre a tradução portuguesa e o texto original. Assim, verificamos emergência de formas vicariantes, omissões e adições que o gráfico IV assinala de modo particularmente agudo. Tàl como no gráfico II, o referente continua a ser o perfil de raisons no texto francês.

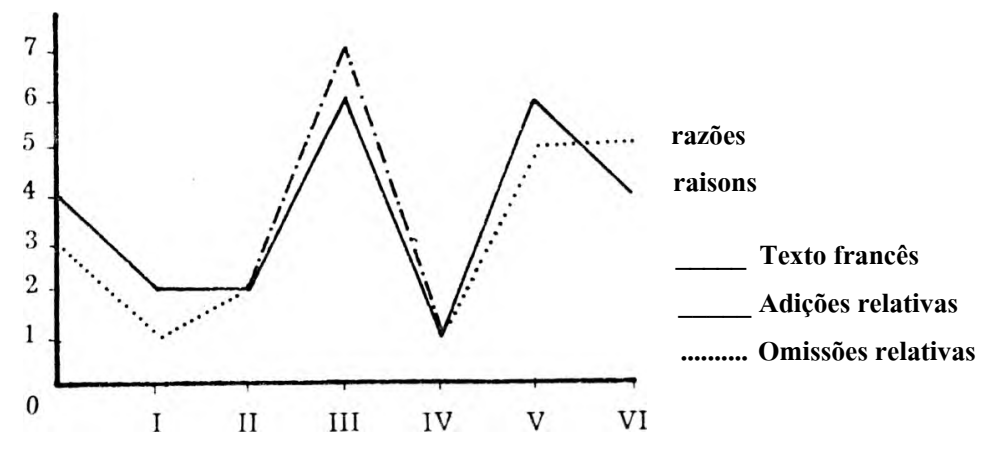

5. Como podemos notar, uma das três formas que a tradução portuguesa apresenta como formas vicariantes de raison é a forma natureza. Dada a importância desta forma no léxico do autor e particularmente nesta obra, parece-nos importante proceder a um cotejo das formas nature e natureza. Tal estudo permitir-nos-á igualmente uma aproximação mais significativa da tradução que vimos examinando.

5.1. Estudo lexicográfico de uma das formas vicariantes de raison na tradução portuguesa: natureza e nature.

Contrariamente ao uso parcimonioso do seu plural $\left({ }^{172}\right)$, a forma nature tem um número de ocorrências que faz deste

(in) A.T. IX. 28.

(1T2) Natures, apresenta três ocorrências nas Meditações, respectivamente uma no resumo, outra na primeira e outra na quinta meditação. A tradução portuguesa restitui fielmente essas ocorrências. 


\section{Antonio Sérgio}

termo o termo mais importante relativamente às formas lexicalizadas e o $52 .^{\circ}$ relativamente à totalidade das formas utilizadas na composição da obra.

A comparação estabelecida entre os dois textos revelamos divergências significativas quanto ao número de ocorrências e à sua distribuição. $\mathrm{O}$ quadro que apresentamos patenteia essas divergências.

\begin{tabular}{|l|c|r|r|r|r|r|r|r|}
\multicolumn{1}{l|}{} & Totais & 0 & I & II & III & IV & V & VI \\
\hline nature & 115 & 5 & 4 & 12 & 20 & 11 & 14 & 49 \\
\hline natureza & 102 & 7 & 2 & 7 & 15 & 7 & 15 & 49
\end{tabular}

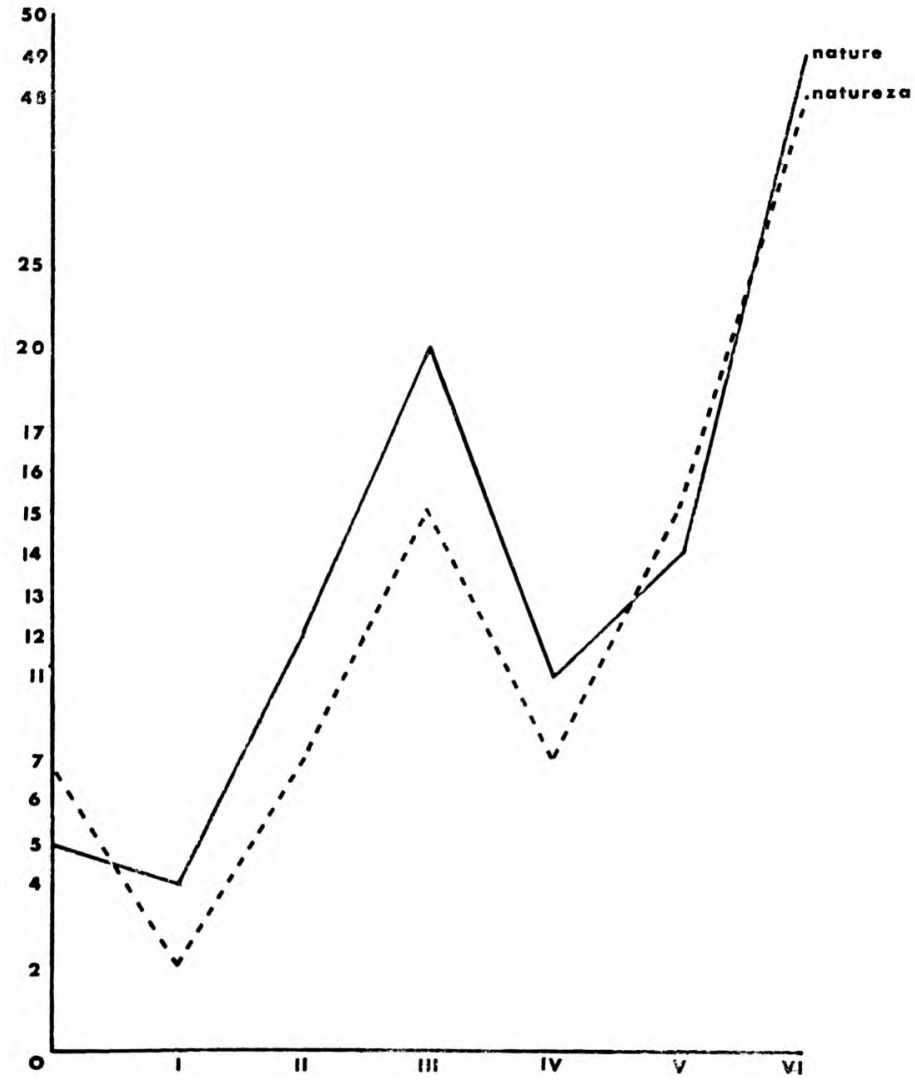


5.3.Um rápido exame do quadro de distribuição e do gráfico das ocorrência de nature e natureza revela-nos: a) a alta frequência da forma nature na meditação sexta, facto que confirma amplamente as intenções do autor: estabelecer os fundamentos da Física...; b) as notáveis divergências existentes entre a disposição arquitectónica dos dois textos relativamente às formas comparadas. Tais discrepâncias estão intimamente relacionadas com algumas omissões, vicariâncias e adições. São esses os pontos que trataremos após uma consideração global sobre a tradução de nature.

5.3.1. Dado o número importante das ocorrência desta forma é-nos impossível produzir aqui uma análise detalhada da sua tradução. Podemos no entanto apresentar uma síntese da consulta das tabelas de concordâncias diacríticas do termo. Tais tabelas que põem em relevo os contextos e o léxico satelizado por nature permitem-nos um avanço na compreensão das micro-estruturas organizadoras da obra e sobretudo colocam-nos em posição de avaliar as consequências de certas opções feitas na tradução.

Assim, nature aparece-nos em vários sintagmas: a) nature corporelle; $b$ ) nature du corps ou nature de corps; $c$ ) nature ou essence; d) de sa nature (para significar as determinações devidas à natureza); e) ma nature (para designar a finitude do homem); f) nature de mon esprit; g) nature intellectuelle; h) nature qui pense; i) la nature de lliomme (referido à união das substâncias). Verificam-se ainda utilizações de nature relativamente a: j) determinações necessárias; 1) união das substâncias; m) Deus; n) ordem do universo.

5.3.2. Entre os diferentes blocos polarizados por nature, blocos bem elucidativos da linguagem e das disposições do autor relativamente à Física, à Meta-física e à Teologia destaquemos o sintagma de sa nature. As suas cinco ocorrências, $(0.02 .50 ; 2.13 .17 ; 2.15 .05 ; 6.61 .46 ; 6.62 .01),\left({ }^{173}\right)$ aparecem como um dos componentes de um conjunto com as seguintes variantes: à sa nature $(5.46 .23)\left({ }^{174}\right)$; en sa nature $(4.38 .43)\left({ }^{175}\right)$;

(173) A.T. IX. 10, 20, 22, $67(2 \mathrm{x})$.

(1M) A.T. IX.52.

(175) A.T. IX.44. 


\section{Antonio Sérgio}

sa nature $(2.15 .05 ; 3.26 .08)\left({ }^{176}\right)$ e enfim sa nature est $(4.39 .19$; $4.42 .15 ; 6.62 .15 ; 6.62 .26)\left({ }^{177}\right)$.

5.3.3. A verificação da tradução da expressão de sa nature revela-nos duas distorções importantes $\left({ }^{178}\right)$ :
0.02 .50
(ce que je ne distingue point), est
S $\quad .4 .19-20$ immortelle de sa nature. : (de que não faço distinção), é imortal por natureza.
2.13 .17
S. 25.23
de sa nature
sobre o que fosse

5.3.4. Do ponto de vista estritamente lexical, as duas distorções apontadas podem ser consideradas importantes, sobretudo porque o texto das Méditations não apresenta nenhuma ocorrência da expressão par nature. Fundamentalmente, aquilo que nos determinou a apresentar estes exemplos foi a necessidade de chamar a atenção para o seguinte facto: quando procedemos a um estudo local dos dois léxicos e observamos que a tradução portuguesa restitui o termo estudado, isso não garante de modo algum que os constituintes imediatos - na circunstância o sintagma de sa nature - não tenham sido modificados.

\subsection{Omissões $\left({ }^{179}\right)$}
1.06 .32
et autres choses de cette nature
S. 12.01 e outros casos semelhantes

\subsection{8 .11}

S.14.25

de cette nature

2.13 .03 da mesma espécie

S.25.09-10 de ma seule nature meu próprio ser

$\left.C^{76}\right)$ A.T. IX. 22,32.

$\left({ }^{\mathrm{m}}\right)$ A.T. IX. 45, 48, 68 (2x).

(m) A.T. IX. 20.

(179) Referências naed. A.T. das omissões de nature: A.T. IX.

14, 16, $20(2 x), 22(2 x), 23,28,37(2 x), 39(2 x), 44,45,48,49,51,61$. 


\section{António Sérgio tradutor}

2.13 .17

S.25.23

2.14 .41

S .28.15

2.15 .11

S.29.05 de sa nature

sobre o que fòsse

que Fou rapporte à la nature du corps

que se refere ao corpo

appartiennent à ma nature

me pertencem

2.16.04 : et qui appartiennent à ma propre nature

S .30.25-26 : e que ao meu ser pertencem

3.21.38 une telle nature

S.43.16 de tal forma

3.30.17 que ma nature

S.59.05 o meu espirito

3.30.28 : que j'attribue à la nature d'un Dieu

S.59.14-15 que atribuo a Deus

3.32.50 la cause que l'on attribue à ma nature

S.63.28 - a causa que me produziu

64.01

3.33.03 j'attribue à la nature Divine

S.64.03 atribuo a Deus

4.38.43 très parfait en sa nature si elle est regardée

S.75.01 perfeitíssimo, pelo contrário* desde que o consideremos

4.39.19 qui soit due à sa nature

S.75.19 que lhe fosse devida

4.42.24 perfection en ma nature, de ce que je puis former

S.81.24 perfeição para os poder formar

4.43.17 faiblesse en ma nature, que je ne puis attacher continuellement

S.83.14 essa fraqueza de não poder em contínuo 


\section{António Sérgio}

5.45.46 : propriétés touchant leur nature

S.88.19 : propriedades delas

6.55.40 : fait tel par la nature, que je me trompasse

S. 109.21 : de tal maneira que me enganasse

\subsection{Vicariâncias}

Sendo uma das vicariantes que a tradução portuguesa substitui a raison, a forma nature suscita ela própria algumas formas que tendem a substituí-la. Os principais desses termos são: espécie, semelhantes, ser, forma e espírito. As formas retrovertidas destes cinco termos encontram-se todas no texto de Descartes mas com uma frequência e uma distribuição que as distinguem de nature: semblables, T.35; espèce, T.3; être, T.34; forme, T.2 e finalmente, esprit, com uma totalidade de 116 ocorrências. A discrepância frequencial entre o termo nature e as suas vicariantes sublinha de modo patente o afastamento que a tradução portuguesa tem em relação ao texto francês.

\subsection{Adições}

Tal como aconteceu em relação a razão e razões, consideramos dois grupos de adições. Um relativo aos tópicos que precedem cada meditação e o outro relativo ao próprio texto.

5.6.1. Relativamente aos tópicos

S .40.24 : ter existido sempre, a natureza da duração

S.85.10 cousas cuja natureza é verdadeira e imutável

S. 100.14 : Que tudo o que a natureza nos ensina

S.100.18 Que há ainda verdade no que a natureza

S. 100.22 parecem ser ensinadas pela natureza

S. 100.23 Que cumpre entender aqui pela palavra «natureza»

S.100.24: a julgar pelos sentidos da natureza das cousas 


\section{Antonio Sérgio tradutor}

S.100.33 : que a natureza nos impele directamente

S.101.16 : que a natureza do homem pode ser defeituosa

S. 101.20 : reconhecer a inferioridade da nossa natureza

\subsubsection{Relativamente ao texto $\left({ }^{180}\right)$}

S.3.14 reconhecemos que a natureza do espírito (0.02.21) (sem equivalente no texto francês)

S.5.25 Ao mesmo tempo se explica a natureza do erro 0.03.24 et ensemble est expliqué en quoi consiste la raison de Terreur

S.86.06 isto é, sobre a natureza do meu espírito

5.44.06 c'est-à-dire celle de mon esprit

S.89.22 à natureza desse número

5.46.25 ou de ce nombre

$\begin{array}{cl}\text { S.119.12 } & \begin{array}{l}\text { sentimentos íntimos que a mesma natureza pôs } \\ \text { em mim }\end{array} \\ 6.60 .47 & \text { sentiments intérieurs qu'elle a mis en moi }\end{array}$

5.7. Tal como nos casos anteriores (gráficos I e II) o levantamento lexicográfico global das formas nature e natureza permitiu-nos estabelecer um quadro e o gráfico $V$, relativos à distribuição das formas nos dois conjuntos. Uma comparação local das formas e a atenção à sua distribuição arquitectónica revelaram-nos omissões e adições que nos permitem corrigir o perfil traçado no gráfico $V$. Assim, o gráfico VI entra em consideração com as oscilações locais das ocorrências natureza e define em relação à distribuição de nature linhas de omissão relativa e de adição relativa. ${ }^{*} 11$

11, 52, 57, 66.

$\left.{ }^{18 \circ}\right)$ Referências na ed. A.T. das adições de natureza: A.T. IX 


\section{Antonio Sérgio}

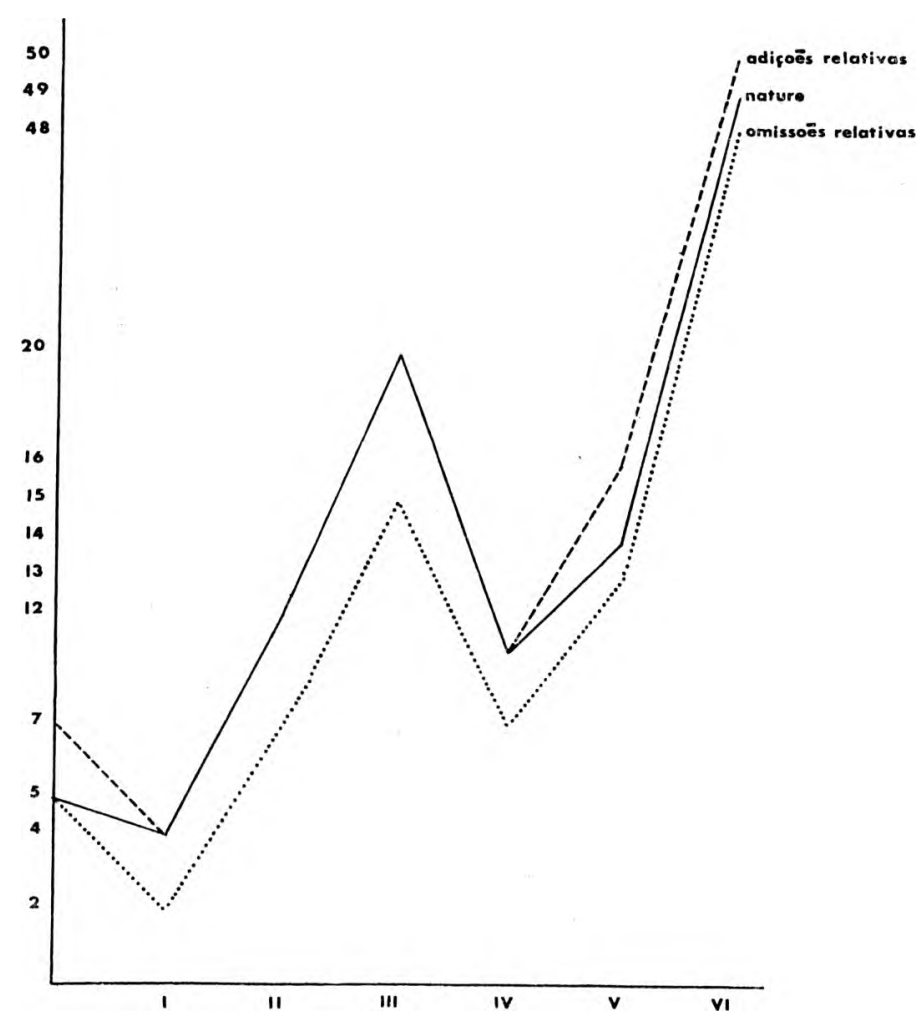

III

Uma leitura da única nota que A. Sérgio consagra à tradução de que nos ocupamos, revela-nos posições e preocupações que devem ser tomadas em consideração para uma compreensão mais exacta do seu trabalho $\left({ }^{181}\right)$.

A associação dos aspectos relevados nessa leitura tende a formar grupos temáticos coerentes, cuja enumeração suscitará alguns breves reparos.

('S1) A importância dos aspectos postos em relevo na Nota do tradutor foi amplamente confirmada pela leitura que podemos fazer da Correspondência dirigida por A. Sérgio a Joaquim de Carvalho entre os anos de 1927 e 1933. Utilizaremos na nossa anotação os elementos que essa leitura nos forneceu como elementos confirmadores e amplificadores das preocupações expressas na Nota terminal à tradução das Meditaç̃os. Insistimos particularmente sobre a importância destes elementos, pois só eles são susceptiveis de poder situar e por vezes corrigir, aspectos que tanto ao nivel da tradução, como da Nota terminal nos aparecem como demasiado superficiais. Ao permitir 


\section{Caracterizado por fortes disposições didáctico-funcio-} nais, surge um primeiro grupo definido por alusões à especificidade do público a quem o texto traduzido se destina $\left({ }^{82}\right)$, e por frequentes interpelações desse mesmo público $\left({ }^{183}\right)$.

examinar as relações reais que se estabeleceram entre os dois homens, a publicação da Correspondência de Exílio torna possivel algo de decisivo: um detalhado restabelecimento da genética de algumas das ideias directrizes do pensamento de A. Sérgio. Permitirno-nos de realçar uma, que nos parece ser uma determinante capital do pensamenco e da acção de A. Sérgio: o desejo de ver restabelecida «a liberdade de pensamento e crítica» (25.V.1927).

${ }^{182}$ ) Os reparos consignados na Nota são «dedicados aos jovens estudiosos que pretendem iniciar-se na filosofia, e aos quais principalmente se destina esta coleeção» (p. 133). Na Correspondência, este aspecto aparece como uma preocupação determinante, iníimamente conexa com a de formação de uma "elite» (8.V.1929). Duas referências à tradução das Meditações colocam-na explicitamente: a) «Suponho que a coleeção se destina sobretudo aos estudantes de filosofia e que tem o carácter de iniciação» (8.IV.1930); b) «Consola-rne a idea de que a minha tradução das Meditações poderá servir para as suas perlecções cartesianas aos rapazes» (13.VII.1930). Mas, desde 1927, tanto a situação cultural do país, como o público estão omnipresentes. Referindo-se à necessidade de editar uma História da literatura portuguesa, (a de Clive Bell), A. Sérgio escreve: a) «faz muita falta à cultura nacional» (4.IV.1927). Numa outra carta, referindo-se à mesma obra, acrescenta: d) «o livro faz falta às nossas escolas e estudantes, que não conseguiram até hoje um manual apresentável da nossa literatura», e prossegue: «Pedem-me às vezes que aconselhe um livro; aponto o Bell, mas nem todos lêem inglês, e o original além disso é caro» (24.IV.1927). Por fim, em duas cartas datadas de 1932, podemos notar os marcados aspectos pedagógicos da questão: e) «precisamos de acabar com o velho e condenado sistema das selectas, que nenhuma nação civilizada usa, e obrigar os estudantes do liceu a estudar e a comentar obras inteiras de autores nacionais. Corno é fatal que um dia se decrete isso, a Imprensa da Universidade, iniciando a série, teria um avanço sobre todos os outros editores, além da honra de promover um melhoramento pedagógico que se impõe», segue-se uma lista de obras de autores portugueses e brasileiros, (7.II.1932). Na segunda carta, A. Sérgio escreve: f) «Espero a sua opinião, não só quanto à edição deles (dos Retratos de mulheres, de Sainte-Beuve) mas também quanto à minha idea de uma Biblioteca Clássica (originais e traduções) para uso dos rapazes do liceu», e prossegue: «O Agostinho da Silva diz-me que nos liceus de província não é possível fazer 1er os autores exactamente porque não há edições ao alcance dos rapazes», e mais adiante: "Quanto aos opúsculos pedagógicos.... talvez pudéssemos começar por uma exposição do plano Dalton junta a: uma exposição do método Cousinet escrita por ele próprio» (18.11.1932).

${ }^{183}$ ) Registamos três interpelações que marcam suficientemente as preocupações didácticas do tradutor: a) a propósito da significação escolástica de alguns termos que Descartes utiliza: «Lembramos ainda ao leitor...." (p. 133); b) referindo-se ao Cogito, «note o leitor porém....» (p. 135); c) por fim, relativamente à prova ontológica, quando é indicada «ao leitor a tão célebre objecção de Kant....» (p. 135). 
Contribuem para uma melhor definição deste grupo, a tematização explícita da necessidade de apoiar a tradução por um sistema de anotação $\left({ }^{184}\right)$, assim como um factor corre-

(181) ^al tematização é constituída respectivamente pelo tom negativo e assertórico da primeira, e pelo tom dogmático da última frase: «Não cabem, no plano da biblioteca de Filósofos e Moralistas, nem minuciosos comentários nem desenvolvidas anotações» (p. 133); quanto à última frase, ela aparece no seguimento do desejo expresso de dedicar um amplo estudo consagrado à tradução de Descartes. O título desse estudo seria: "Exame de consciência de um tradutor de Descartes. Para lá iriam as anotações que por vários motivos descouberam aqui» (p. 136). Joaquim de Carvalho deve ter sido o primeiro a incitar A. Sérgio a concretizar tal estudo: «Não posso escrever por enquanto o Exame. Precisaria de me assegurar primeiro da plausibilidade de certas hipóteses por meio de uma cuidadosa confrontação de textos, etc.» (12.XII.1930). Tal estudo não consta na Bibliografia de A. Sérgio. Muito possivelmente ele nunca foi escrito.

Os elementos fornecidos pela Correspondência, transformam radicalmente aquilo que se pode ler na Nota terminal, relativamente à questão da anotação. Relativamente à anotação de As Últimas Conversações, anotação em que apenas devemos a A. Sérgio a sua tradução e a nota número quatro (ob. cit. p. 104), sendo as restantes da autoria do editor francês, a Correspondência apenas nos informa sobre a inquietude de A. Sérgio face a um extravio das mesmas (cf. carta de 13.III.1930). Como veremos mais adiante, a tradução de Descartes e ocasião de importantes declarações de A. Sérgio relativas à função e necessidade de um sistema de anotação. Mas é relativamente à anotação da tradução de $B$. Russell que encontramos elementos que nos permitem apreciar de modo mais exacto a posição de A. Sérgio sobre tal questão. Em cartas de 1930, ele escreve: «Rogo-lhe que me diga com tôda a franqueza se acha má a minha idea de acrescentar à tradução do Russell umas notazinhas breves da minha lavra», e termina: «Anotado ou não anotado, farei o trabalho com igual gôsto» (10.11.1930). A resposta de J. de Carvalho não é difícil de configurar dado o tom da seguinte passagem de uma outra carta datada de 22.11.1930: "Vejo que lhe não agrada a idea de se acrescentarem no fim dos volumes quaisquer anotações. Reconheço que o precedente pode trazer os seus perigos, e acho igualmente fundados os dois arbítrios: anotar, e não anotar». Portanto, tudo nos leva a pensar que são os limites impostos pelo responsável da Imprensa da Universidade, limites esses possivelmente determinados por uma conjectura complexa..., que levam A. Sérgio a restringir o seu trabalho de anotação.

Esta mesma questão foi igualmente colocada relativamente à tradução dos Novos Ensaios de G. W. Leibniz: a) «Creio que se não poderão dispensar algumas notas, postas no fim, como a das Meditações» (5.IV.1931), e Sérgio esclarece: b) «Como sabe, o texto dêste jacaré exige muito mais anotações que o de Descartes. As notas poderiam ser de duas espécies: Filosóficas, para esclarecimento doutrinal de certos pontos do texto; eruditas, para explicação de muitas referências a pessoas, obras, etc. Que quere que faca? Nenhumas? De umas e de outras?» (15.V.1931), e ainda, c) «Pedi duas colecções de segundas provas para escolher as frases a que será indispensável fazer uma anotação no fim do volume, à alemã̃» (22.VI.1931). Per fim, em duas outras cartas, A. Sérgio explicita de modo particularmente claro, não 
lacionado com os anteriores, caracterizado pelas transformações estilístico-lexicais que o tradutor assinala nos seguintes termos: «Buscámos que a versão presente fosse o mais clara e o mais fácil possível para o leitor moderno e da nossa língua. Resultaram desse nosso empenho certas particularidades de vocabulário» (p. 133) $\left.{ }^{185}\right)$.

2. Grupo de elementos paleográfico-lexicais, a que o tradutor se refere expressamente notando: «Confrontamos sempre, ao traduzir, o texto latino e francês» (p. 133) $\left.{ }^{186}\right)$.

Sobre este aspecto, notaremos que em nenhuma passagem desta tradução são esclarecidos os seguintes pontos: a) quais as edições desses textos que foram cotejadas; b) qual a edição considerada como referente da tradução $\left({ }^{187}\right)$; c) quais as razões que determinaram tal cotejo e, finalmente, d) quais as passagens da tradução em que foi dada preferência a um ou outro dos textos originais.

só a sua posição relativamente à função didáctica das anotações como aos limites com os quais se debate: d) «Enviei há dias o resto da tradução do Leibniz e as notas relativas à parte já paginada. Se tiver tempo de as 1er, rogo me diga com toda a franqueza se acha bem. Procurei anotar o menos possível; mas pareceu-me que o texto está cheio de alusões sobre que o principiante necessita de esclarecimentos: é aos principiantes me parece que se deverá dirigir sobretudo a colecção» (22.VII.1931); e) «Gostaria só de saber se acha preferível com notas ou sem elas», (23.1.1932?).

$\left({ }^{185}\right)$ desejo de clarificar os textos traduzidos aparece na Correspondência, a) relativamente a Descartes: "procurei dar ao texto português mais ar, clareza e elegância que o francês, e sobretudo melhor ritmo, melhor musicalidade» (8.IV.1930); b) relativamente à obra de Renouvier: «Procurei tornar a tradução mais clara que o original» (13.XII.1929); c) e por fim em relação a Leibniz: "Como o estilo dos Novos Ensaios não é dos mais belos, procurei ter mais elegância e mais música que o original. Creio ser bom serviço à filosofia o tornar os seus textos atraentes e formosos, na medida do possível» (18.V.1931).

$\left.{ }^{186}\right)$ Uma carta datada de 8.IV.1930 confirma este ponto: «Servi-me bastante da lição latina».

${ }^{(m)}$ Duas alusões à obra de $\mathbf{C h}$. Adam, Vie et oeuvres de Descartes, (tomo XII das Oeuvres de Descartes), mostram-nos que A. Sérgio conhecia a edição A.T. Essas alusões são as seguintes: a) «O caso do baptizado protestante da pequena (da filha de Descartes) vem no Ch. Adam» e b) «Foi também pelo Ch. Adam que me fixei no facto das amizades protestantes do Descartes» (12.XII.1930). Sobre este ponto capital, foi necessário esperar pela publicação da tradução dos Novos Ensaios, para termos a seguinte informação: «A melhor edição de Descartes é a de Adam e Tannery; dela nos servimos para a nossa tradução das Meditaçôes» (ob. cit., nota 32, p. 142).

Relativamente à tradução de outras obras, A. Sérgio mostra-se bastante mais atento à importância que tem a escolha do referente. Assim, a propósito da tradução da obra de Leibniz: «O Boutroux deu preferência ao texto de Gerhardt, por motivos que me pareceram 
Como realçamos na primeira parte do presente estudo $\left({ }^{188}\right)$, há entre as três primeiras edições das Meditationes/ /Méditations, um importante conjunto de divergências. Dado que essas três edições conheceram a aprovação do autor, estamos em face de três versões de uma mesma obra que tudo leva a considerar como três textos originais.

Insistimos sobre este ponto, pois, após ter feito referência ao cotejo dos textos latino e francês, numa outra passagem da sua Nota, A. Sérgio escreve: «Não poderíamos deixar de traduzir pela palavra «imagem»o vocábulo «image» empregado no original» (p. 134), ( $\left.{ }^{189}\right)$. Como interpretar esta alusão ao original. Visivelmente o termo é utilizado como equivalente da expressão texto de referência. Foi tal interpretação que nos conduziu a utilizar o texto francês como referente da análise lexical a que procedemos na segunda parte deste estudo $\left({ }^{190}\right)$. Todavia, se podemos verificar que a tradução portuguesa segue preferencialmente o texto francês, um importante número de factos de ordem paleográfico-lexical, provam que o tradutor se concedeu a liberdade de cons-

fundamentados. Foi também pelo Gerhardt que se inclinou o mais considerável tradutor inglês dos Novos Ensaios, Langley. Os pequenos desvios do Boutroux em relação ao texto por ele escolhido afiguram-se-me, outrossim, plenamente razoáveis. Decidi, por isso tudo utilizar-me da edição Boutroux». Por fỉm, em relação à tradução do Treatise concerning the Principle of human knowledge de Berkeley, A. Sérgio escreve: "Mandei vir de Inglaterra um exemplar do original.... Marcarei na versão (entre colchetes, por exemplo), as adições feitas por Berkeley na 2. ${ }^{a}$ ediçãa....» (18.V.1931).

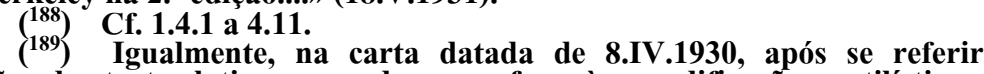
à lição do texto latino, quando se refere às modificações estilísticas, A. Sérgio, alude ao texto francês e não ao texto latino: A mesma ambiguidade persiste quando $A$. Sérgio se refere por exemplo às peças a traduzir. Assim, na carta datada de 22.III.1930, o referente é a versão francesa. Com efeito, A. Sérgio refere-se à «carta preliminar a Messieurs les Doyens et Docteurs....», enquanto na carta datada de 2.IV.1930, o referente desta peça passa a ser o latino: «Sapientissimis Clarissimisque Viris...

$\left({ }^{10 \circ)}\right.$ Cf. II. 4 a 4.8.4. e II. 5 a 5.7.

(191) Tais intersecções são facilmente detectáveis não só do ponto de vista paleográfico, como ortográfico e lexical Assim temos:

a) as variações paleográficas registadas neste estudo sob II. 2.1 e 2.2.;

b) algumas variações ortográficas tais: natureza $(\mathbf{S . 9 5 . 2 6 )}$ que segue o latim naturâ (A.T.VII.70), pois o texto francês imprime Nature (A.T.IX.55); infiéis, (S.V.17), que segue o latim infide'ibus (A.T.VII.2), que o texto francês imprime Infidèles (A.T.IX.5); e por fim, círculo e a'ma (S.V.Il e VII.6), formas que no texto latino aparecem ortografadas, circulum e animam (A.T.VII.2), e no texto francês Cercle e Ame, (A.T.IX.5); c) como variações lexicais podemos verificar que aparecem traduzidas no texto português, frases que só existem no texto 
trair um texto heteroclítico, cujas ambiguidades resultam não só de um apelo indiscriminado às edições latina(s) e francesa $\left({ }^{191}\right)$, mas também de intervenções que nenhum editor ou tradutor tinham ousado até esse momento $\left({ }^{192}\right)$.

3. Um terceiro grupo de aspectos, que designaremos por léxico-conceptuais, aparece como uma das consequências da vontade expressa pelo tradutor em tornar a sua versão «o mais clara e o mais facil possível» (p. 133). Podemos delimitá-lo pelos seguintes pontos: a) uma breve chamada de atenção e determinação do "significado escolástico» (p. 134). que Descartes atribui aos termos objectivo, formal e eminente ${ }^{193}$ ); b) a constatação da ambiguidade que caracteriza a utilização cartesiana do termo image, e por fim, c) a proposta de um conjunto de termos vicariantes para traduzir as formas francesas douleur e sentir.

francês: «c'est-à-dire participent par représentation à plus de degrés d'être ou de perfection" (A.TJX.32), frase traduzida do seguinte modo: «participarão, por representação, de mais graus de ser ou de perfeição» (S.50.07.08) ; e a seguinte frase que só existe no texto francês: «sans interrompre l'ordre du méditer» (A.T.VII.36), traduzida do seguinte modo: «sem que deixe nunca de me sujeitar à ordem de meditar» (S.44.20-21). Todavia, por vezes, A. Sérgio traduz frases que só existem no texto latino. Temos como exemplo: "pois não cria que pertencesse à natureza do corpo o ter a capacidade de se mover a si mesmo como o de sentir ou a de pensar» (S.26.06-09), que visivelmente é a tradução da frase latina: «namque habere vim seipsum movendi, item sentiendi, vel cogitandi, nullo pacto ad naturam corporis pertinere judicabam» (A.T.VII.26), e não a frase do texto francês: "car d'avoir en soi la puissance de se mouvoir, de sentir et de penser, je ne croyais aucunement que l'on dût attribuer ces avantages à la nature corporelle» (A.T.IX.20-21). Algo idêntico acontece com a seguinte frase: «mas também no que se refere à natureza corpórea, enquanto objecto da matemática pura» (S.97.18-20), tradução da passagem latina: «naturâ corporeâ, quae est purae Matheseos objectum» (A.T.VII.71), frase que no texto francês aparece sob a forma: «nature corporelle, en tant qu'elle peut servir d'objet aux démonstrations des Géomètres» (A.T.IX.56).

$\left.{ }^{192}\right)$ Referimo-nos não só ao conjunto de peças com o qual o volume se inicia, mas especialmente aos resumos com os quais o tradutor faz começar cada uma das meditações.

${ }^{(103)} \mathrm{Na}$ Correspondência encontramos duas referências à mesma questão: a) «Não the parece essencial explicar o significado dos termos formal, objectivo e eminente, que Descartes emprega na sua acepção escolástica?» ( $P$. S. da carta de 2.IV.1930), e "Creio indispensável, pelo menos uma nota de vocabulário, por causa das palavras que Descartes emprega na sua acepção escolástica, bastante diferente da que têm hoje» (8JV.1930). 
Dada a estrita relação existente entre este grupo de elementos e o tema que nos propusemos tratar, não poderíamos deixar de o considerar um pouco mais detalhadamente.

3.1. Em relação à forma lexical image, A. Sérgio nota: «Não poderíamos deixar de traduzir pela palavra «imagem» o vocábulo «image» empregado no original, em vários passos, como equivalente da palavra «idea» (p. 134) $\left({ }^{194}\right)$.

3.1.1. Uma verificação das quatro ocorrências do termo image do texto francês, permite-nos confirmar a sua exacta restituição na tradução portuguesa $\left({ }^{195}\right)$. Com efeito, relativamente a este termo, apenas constatamos uma anomalia: a adição na meditação terceira de uma ocorrência da forma imagem, que nem a edição latina, nem a edição francesa confirmam $\left({ }^{196}\right)$.

3.1.2. Mais complexa é a restituição do termo idée na versão portuguesa.

Assim, às oitenta e cinco ocorrências que essa forma apresenta $\left({ }^{197}\right)$, correspondem na tradução portuguesa: a) setenta e nove restituições correctas do termo idée por idea $\left({ }^{198}\right)$;

(iw) $p_{\text {or vezes }} £$ precisamente $\mathbf{o}$ contrário que acontece: lá onde o texto francês apresenta idées, a tradução portuguesa restitui imagens. Tal acorre nomeadamente na seguinte passagem: «tais imagens devem vir de alhures» (S.48.09), tradução de: «ces idées doivent venir d'ailleurs» (A.T.IX.31), a que corresponde no texto latino: «quamvis idea illae a volontate....» (A.T.VII.39).

${ }^{(195)}$ As ocorrências da forma image são as seguintes: Cogito 75 : 2.14.37; 3.34.21; 4.39.49; 5.48.25, respectivamente traduzidas em: S.28.11; 66.22; 77.02; 93.12.

${ }^{196}$ ) A adição é a seguinte: «e parece-me o sol, segundo esta imagem, muitas vezes maior que toda a terra» (S.49.05-07); «il me paraît plusieurs fois plus grand que toute la terre» (A.T.IX.31), tradução da frase latina: «per quam aliquoties major quam terra exhibetur» (A.T.VII.39).

$\left({ }^{19 T}\right)$ Cf. Cogito 75 , p. 91.

$\left.{ }^{198}\right)$ De notar que algumas dessas restituições correctas aparecem integradas em frases distorcidas. Notaremos os seguintes casos: «l'idée que j'ai de la divinité» (3.30.47), traduzida por «a ideia que eu faço de Deus» (S.60.08); "l'idée que je conçois de Dieu» (3.32.03), traduzida por: «na idea de Deus» (S.62.09), e por fim, «ait mis en moi cette idée pour être comme la marque» (3.34.16), frase traduzida do seguinte modo: «haja posto em mim essa sua idea, qual marca» (S.66.17). 
b) duas ocorrências onde o singular idée é transformado no plural ideas $\left({ }^{199}\right)$; c) enfim, quatro omissões $\left({ }^{20 \circ}\right)$.

Para além destas anomalias, notaremos que a tradução portuguesa acrescenta dezoito ocorrências da forma idea cuja distribuição é a seguinte: seis no resumo que o tradutor acrescenta à meditação terceira $\left({ }^{201}\right)$; uma ocorrência, no resumo acrescentado à meditação quinta $\left({ }^{202}\right)$; uma ocorrência acrescentada ao Abrégé /SSynopsis $\left({ }^{203}\right)$; nove adições relativas à meditação terceira $\left({ }^{204}\right)$, e finalmente, uma adição relativa à meditação sexta $\left({ }^{205}\right)$.

3.1.3. Dada a vicariância de significação que o tradutor assinala, será útil uma comparação da distribuição lexical das formas idée, idées, image e images $\left({ }^{206}\right)$ :

\begin{tabular}{|c|c|c|c|c|c|c|c|c|}
\hline & $\mathrm{T}$ & 0 & $\mathrm{I}$ & II & III & IV & $\mathrm{V}$ & VI \\
\hline idée & 85 & 4 & 0 & 0 & 53 & 12 & 9 & 7 \\
\hline idées & 65 & 0 & 0 & 0 & 44 & 2 & 3 & 16 \\
\hline image & 4 & 0 & 0 & 1 & 1 & 1 & 1 & 0 \\
\hline images & 12 & 0 & 1 & 2 & 7 & 0 & 1 & 1 \\
\hline
\end{tabular}

(199) Respectivamente: «et c'est à celles-là seules que convient proprement le nom d'idée», (3.22.26-27), e, «mais on doit savoir que toute idée étant un ouvrage de l'esprit» (3.26.07-08), traduzidas por: «e a esses convém o nome de ideas» (S.45.01), e «mas cumprirá ter presente que, visto que as ideas são obras do espirito» (S.51.21).

$\left({ }^{20}\right)$ Essas omissões são as seguintes: Cogito 75: 3.29.25; 3.30.08; 3.33.24; 6.59.25. Elas deveriam situar-se em: S.57.14; $58.23 ; 64.26$ e 116.20-21.

(201) Respectivamente: S.40.03; 40.11; 40.14; 40.15; 40.20 e 40.32.

(202) Em, S.85.03.

(203) Em, S.5.17.

(204) Essas adiç̃̃es são as seguintes: S.50.09; 50.12; 53.13; 53.16; $57.25 ; 57.26 ; 64.10 ; 65.07$ e 66.13 , que se deveriam encontrar no texto francês, respectivamente em: Cogito 75 : $3.25 .19 ; 3.25 .22 ; 3.27 .02 ; 3.27 .05$; 3.29.35; 3.29.36; 3.33.11; 3.33.34 e 3.34.12-13.

De notar ainda que: a) três dessas adições da forma idea, aparecem para traduzir o termo idées: «une de mes idées» (3.27.02), «de uma idea minha» (S.53.13); «les perfections dont elle conçoit les idées, c'est-à-dire» (3.33.11), "as perfeições cuja idea contiver em si, isto é» (S.64.10), e finalmente: «les idées» (3.33.34), expressão traduzida por «a idea» (S.65.07); b) uma outra vez, idea (S.57.25) aparece como tradução da forma notion (3 29.35). (6.62.08).

$\left.\mathrm{C}^{205}\right) \mathrm{Em}, \mathrm{S} .121 .22$, ocorrência inexistente no texto francês

$\left.{ }^{206}\right)$ Cf. Cogito 75, p. 91 
Notaremos ainda que relativamente à totalidade do léxico das Méditations, as formas idée, idées, ocupam respectivamente a sexagésima sétima e a septagésima oitava posição e que relativamente às palavras «plenas» (lexicalizadas), elas são respectivamente a nona e a décima primeira formas mais frequentes. Quanto às formas image e images, elas não aparecem nem entre as duzentas formas mais frequentes do léxico global, e, consequentemente, nem entre as cem formas «plenas» mais frequentes $\left({ }^{207}\right)$.

Do exame da distribuição estrutural destas formas e das suas posições relativamente ao léxico total que a obra mobiliza e ao léxico que a metafísica privilegia, podemos concluir: a) a diferença irredutível das ocorrências das formas idée/idées e image/images; b) algo que qualquer leitura desarmada pode facilmente relevar: que a meditação terceira tematiza de modo particularmente explícito, a problemática idée/ /idées; c) por último, a discreta importância que as formas image/images têm na obra.

3.2. Quanto à tradução da forma lexical douleur, o tradutor faz a seguinte precisão: «para o sentimento contrário ao do prazer adoptamos a palavra «desprazer» e não a palavra «dor» (douteur), que convém reservar para a sensação dolorosa localizável como qualquer outra, da natureza dos fenómenos representativos, e heterogénea, portanto, como o prazer, que é de ordem emocional, afectiva» (p. 133).

3.2.1. Em relação à tradução da forma douleur, verificamos que o tradutor utiliza de um modo geral a forma dor. Tal acontece vinte e três vezes para o total das vinte e cinco ocorrências que se concentram na meditação sexta $\left({ }^{208}\right)$. Só as restantes duas ocorrências recebem como tradução desprazer $\left({ }^{209}\right)$.

No entanto, mesmo se a tradução desta forma aparece como globalmente correcta, não podemos deixar de notar que ela se insere por vezes em frases distorcidas $\left({ }^{210}\right)$.

$\left.{ }^{207}\right)$ Cf. Cogito 75, p. 116.

$\left.\mathrm{C}^{208}\right)$ Cf. Cogito 75, p. 82.

$\left.{ }^{20 y}\right)$ Em francês, déplaisir, termo que não é utilizado nas $M e ́-$ ditations. As ocorrências de douleur traduzidas por desprazer são as seguintes: Cogito 75 : $6.53 .37 ; \mathbf{6 . 5 3 . 3 8}$, respectivamente $S .105 .24$ e 105.25 da tradução portuguesa.

$\left({ }^{2 \%}\right)$ Resultam casos como os seguintes: «cause de la douleur, et de la pensée de tristesse» (6.55.03), «causa da dor e o sentimento de tristeza» (S.55.03); «le sentiment de la douleur» (6.60.03), «sensa- 
Relativamente às disposições da forma dor na tradução portuguesa, relevamos por fim, a presença de uma ocorrểncia dessa forma, no resumo que o tradutor acrescenta à meditação sexta $\left.{ }^{211}\right)$.

3.3. Finalmente, em relação ao termo sentir, A. Sérgio nota: «traduzimos por vezes a palavra sentir por «percepcionar» ou «ter sensações», afim de evitar qualquer confusão com significados daquele vocábulo que se referem aos factos emocionais (afecções, emoções, paixões), e não aos fenómenos representativos (sensações, representações, percepção)» (p. 133).

3.3.1. Tal como acontece com os critérios que justificam as variações de tradução da forma douleur, os critérios alegados para introduzir distinções relativamente à forma sentir, são exteriores ao pensamento de Descartes, contrários às disposições internas da teoria, e consequentemente impróprios para restituírem de um modo exacto, quer o aspecto histórico, quer o aspecto conceptual do pensamento de Descartes.

3.3.2. A verificação da tradução das vinte e três ocorrências que a forma sentir apresenta no texto francês $\left({ }^{212}\right)$, revela-nos um afastamento considerável em relação às opções explicitadas e defendidas pelo tradutor. Assim, encontramos além das variantes anunciadas - percepcionar $\left({ }^{213}\right)$ e ter sen-

ção de dor» (S.117.23), e por fim, «et même que m'en approchant un peu trop près je ressente de la douleur» (6.60.19), frase corn a seguinte tradução: ".... (e até dor, se me aproximar ainda mais)....» (S.118.11-12).

$\left(\begin{array}{c}2 n \\ 2\end{array}\right)$ Cf. S. 101.06.

$(213)$ Cf. Cogito 75 , p. 108.

(213) O verbo «perceptionner» não existe em francês. Nas $M e^{-}$ ditations, encontramos apenas as formas perception e perceptions, respectivamente com quatro e cinco ocorrênicas. As ocorrências da forma sentir que foram traduzidas por percepcionar são as seguintes: Cogito 75: $6.54 .08 ; 6.54 .11 ; 6.55 .32 ; 6.62 .36 ; 6.62 .39$, cujas referências na tradução portuguesa são: S.106.16; $106.20 ; 109.13 ; 122.28$ e 123.04.

Tal tradução coloca fundamentalmente dois problemas: um, relativo às incidências conceptuais de toda a variação lexical, e o segundo, relativo aos critérios que o tradutor alega para fundamentar essa(s) variações.

Sabemos que em Descartes as ideias claras e distintas, têm muitas vezes uma expressão obscura e confusa que ao nível da comunicação, compromete radicalmente a sua transmissão. Sabemos igualmente que a expressão e a linguagem, são parâmetros quasi - impensados da Obra de Descartes, e isso mesmo se desde as Regulä̈ a sus- 


\section{Antonio Sérgio}

sações $\left({ }^{214}\right)$ —as seguintes outras: sentir $\left({ }^{215}\right)$; «sentir» $\left({ }^{216}\right)$; sen-

peita relativa à linguagem dita «natural» tem como contraponto uma importante investigação que deveria conduzir ao estabelecimento de uma linguagem «artificial», bem construída e portanto apta para a transmissão de ideias. (Cf. Regula XVI, A.T.X.455). Portanto, tudo nos leva a pensar que as redundâncias da linguagem natural, sobretudo as suas polissemias, fossem os maiores inimigos do filósofo das ideias claras e distintas. Sendo assim, aquilo que A. Sérgio pretendeu corrigir é um problema interno à teoria, problema cuja desaparição equivale a uma deformação capital da mesma. Tal clarificação aparece-nos como incorrecta quer do ponto de vista léxico-conceptual quer do ponto de vista histórico.

Em relação à coerência dos critérios que determinam tal prática, a consulta da Correspondência revela-nos elementos capitais. Assim, em relação à dificuldade encontrada na tradução do termo percevoir na obra de Renouvier, A. Sérgio escreve: «resolvi-me a criar uma palavra: percepcionar para a tradução de percevoir, ter percepção, porque perceber tem na nossa língua uma acepção vulgar que é bem diferente, e que não podemos suprimir» (13.XII.1929). Mas, como numa visão antecipativa daquilo que mais tarde aconteceu, A. Sérgio acrescenta: «Parecia-me conveniente reunirmo-nos um dia alguns amigos da filosofia, para fixarmos certos pontos do vocabulário filosófico em nossa língua», e A. Sérgio continua: «Agora que decidiu publicar uma biblioteca filosófica, era boa ocasião de fixarmos o vocabulário, para não ficar muito diferente de volume para volume». $E$ sobre a necessidade de criar novas palavras, A. Sérgio lembra: «Há vinte anos quando escrevi a Natureza da afecção, tive que forjar essa mesma afecção».

A propósito da dificuldade de tradução da forma percevoir, A. Sérgio, adianta numa outra carta: «Fica pois percepcionar. Qualquer termo me serve, contudo que designe uma ideia precisa, e que se não preste o confusões, como o perceber» (9.1.1930). Relativamente à linguagem, tal como em Descartes, aquilo que preocupa tanto J. de Carvalho como A. Sérgio, é visivelmente a polissemia: "Concordo absolutamente consigo em que é preciso usar palavras diferentes para ideas diferentes» (9.1.1930). Quando Boileau exprime o paradigma Clássico da relação pensamento linguagem escreve: "Ce que l'on conçoit bien s'énonce clairement, Et les mots pour le dire arrivent aisément», Art Poétique, I. 153-154.

Sem entrar em linha de conta com a «especificidade» das oito variações de tradução que o termo sentir conhece na tradução portuguesa - variações essas que o tradutor não justifica-, somos obrigados a colocar as seguintes questões: a) dado que, para «evitar qualquer confusão» (p. 133), o termo percepcionar, traduz nas Meditações o termo sentir, e que, b) na tradução de As Últimas Conversações, o mesmo termo aparece para traduzir a forma percevoir, c) há entre as formas sentir e percevoir, tal que elas são utilizadas respectivamente por Descartes e por Renouvier uma equivalência, ou será apenas por confusão do tradutor que ambas essas formas aparecem traduzidas por uma forma única?

${ }^{(14)}$ Nas Méditations, Descartes não utiliza a forma sensations. As ocorrências de sentir que foram traduzidas por ter sensações são as seguintes: Cogito 75: 2.13 .46 e 6.59.40, respectivamente, S.26.25 e 111.18 da tradução.

${ }^{215}$ Cf. Cogito $75 ; 2.13 .29 ; 2.13 .47 ; 6.63 .02 ; 6.63 .25 ; 6.64 .06$; 6.64.12; 6.64.13 e 6.64.18, com as seguintes referências na tradução 
tia $\left({ }^{217}\right)$; tendo sensações $\left({ }^{218}\right)$; sofrer... sensações $\left({ }^{219}\right)$; sentir ou percepdonar $\left({ }^{220}\right)$; sentir ou percepcionar ou ter sensações $\left({ }^{221}\right)$; e finalmente, ter percepções $\left({ }^{222}\right)$.

3.3.3. Se considerarmos as propostas de introdução de termos vicariantes, e anomalias registadas na tradução das formas image, douleur e sentir, conjunto ao qual podemos acrescentar as omissões, vicariâncias e adições que neste estudo já foram registadas relativamente a várias formas $\left({ }^{22 S}\right)$ e expressões $\left({ }^{224}\right)$, torna-se particularmente delicado interpretar o importante passo da Nota do tradutor, onde este, a propósito da ambiguidade do termo image se mostra particularmente consciente das incidências conceptuais de toda a modificação lexical: «mas qualquer termo que substituísse o de «imagem» poderia acarretar inconvenientes graves, - entre os quais sobretudo, o de fazer supor no nosso filósofo qualquer idea que não fosse a sua» (pp. 134-135 $\left({ }^{225}\right)$.

portuguesa: $\mathrm{S.26.09} ; 26.25 ; 123.23 ; 124.18 ; 125.21 ; 125.28 ; 126.02$ e 126.08.

$\left.{ }^{21 f 1}\right)$ Cf. Cogito 75: 2.15.40; S.30.11.

${ }^{(m)}$ Cf. Cogito 75: 6.54.04; S.106.11.

$\left.C^{S}\right)$ Cf. Cogito 75: 2.15.48; S.105.02.

$\left.{ }^{219}\right)$ Cf. Cogito 75: 6.55.24; S.109.03.

$\left.{ }^{22 \circ}\right)$ Cf. Cogito 75: 6.53.18; S.105.02.

$C^{21}$ Cf. Coqito 75: 6.53.20; $\mathbf{S . 1 0 5 . 0 5}$.

(222) Cf. Cogito $75: \mathbf{6 . 5 7 . 1 3} ; \mathbf{5 . 1 1 2 . 1 4}$.

II. 5 a II. 5.7.

(223) Para raison/raisons, cf. de II. 4 a II. 4.8.4; para nature, cf. de

(TM) Cf. sa nature, IL 5.3.2.

(225) Encontramos na Correspondência múltiplas referências correlativas desta abertura de A. Sérgio a uma problematização das relações estabelecidas entre pensamento e linguagem.

Como já podemos notar, (cf. nota 213), A. Sérgio insiste desde 1929 sobre a necessidade de fixar um léxico filosófico. Tal necessidade era o prolongamento da sua experiência mais directa: a tradução de Renouvier e a composição de $A$ Natureza da afecção.

Todavia, à medida que $A$. Sérgio se confronta com novas traduções, podemos notar que visivelmente, ele toma consciência não só da problemática inerente à tradução, mas também das dificuldades que a língua portuguesa tem em receber o pensamento originalmente consignado noutra(s) língua(s). Assim, ainda relativamente à tradução da obra de Renouvier, escreve: «À medida que nas traduções fossem aparecendo as dúvidas, poderíamos ir fixando o nosso vocabulário; a sua colecção prestar-se-ia assim a constituir uma espécie de código do nosso vocabulário filosófico» $(\mathbf{9 . 1 . 1 9 3 0 )}$. Em relação à tradução, A. Sérgio nota: «acrescentei uma pequenina nota final, acêrca de certos pormenores de vocabulário», e faz a precisão seguinte: «Gostava de ainda um dia combinar consigo a fixação de um certo número de termos. Para nós, Portugueses, é trabalho particularmente útil, porque estamos no nascimento da nossa literatura filosófica em língua vulgar, 
4.Por fim, destacamos um grupo de aspectos históricofilosóficos, delimitados pelas seguintes questões: a) Cogito; b) prova da existência de Deus, que depois de Kant é designada por prova ontológica, e por último, c) articuladas com as precedentes, aparecem as questões referidas à importância da teologia da época sobre o pensamento de Descartes e à sinceridade do pensamento expresso pelo mesmo na carta dirigida aos teólogos da Sorbonne.

4.1. Relativamente ao Cogito, A. Sérgio, apresenta um conjunto de três enunciados que considera como equivalentes quanto à sua formulação e verosímeis, quanto à sua conclusão. Tais enunciados são em seguida colocados em oposição global com a conclusão de um dos enunciados do cogito cartesiano, conclusão essa considerada como ilegítima. Tal insistência sobre a legitimidade e a ilegitimidade das conclusões do cogito, vai de par com a assimilação deste a um silogismo cujo correlato é a recusa do intuicionismo cartesiano: «Não é uma intuição intelectual, senão uma imagem obscurissima» (p. 135) $\left.{ }^{226}\right)$.

ou romance» (29.XI.1930). A tradução dos Novos Ensaios, relança a mesma questão: «Parecia-me bem ir fixando uma ortografia e um vocabulário para toda a colecção», e mais adiante: «Na tradução dos Novos Ensaios criei o neologismo experienciar, que me parece utilíssimo. Experienciar ficará como o verbo correspondente a Experiência no sentido geral, e experimentar como o verbo correspondente a Experimentação (verificação experimental, prova experimental, etc.). $E x$ perienciar ficará pois significando ter experiência, etc.; experimentar ficará significando realizar experimentação» (22.VI.1931).

As preocupações que A. Sérgio revela quando se lança na tradução do Treatise de Berkeley são notáveis: não só ele consulta uma edição crítica inglesa (cf. carta 18.V.1931), como entra em linha de conta com a tradução francesa que $C h$. Renouvier fez dessa obra. Desse cotejo, resultam observações particularmente pertinentes: «Na versão de Berkeley, o Renouvier traduz ambas as palavras mind e spirit por esprit. Tenciono traduzir a primeira por consciência e a segunda por espírito" (22.VI.1931). (Lembremo-nos apenas da confusão que levou a traduzir sentir e percevoir por percepcionar... cf. nota 213 ).

${ }^{(26)}$ Segundo A. Sérgio, «A conclusão incontestável limita-se a isto: penso, e o pensar existe; ou então: penso, logo existo como forma de pensar; ou ainda: penso, logo existo como actividade pensante. Mas Descartes vai mais longe, e conclui: penso, logo existo como cousa pensante» (p. 135). Sobre esta questão convém notar o seguinte: a) os enunciados que $A$. Sérgio apresenta não são os de Descartes; b) são omitidas todas as referências, internas à teoria, capazes de fazer avançar na compreensão deste problema; c) são igualmente omitidas todas as referências às polémicas que as diferentes enunciaçães de tal pensamento suscitaram desde a publicação do Discours (1637) à publicação dos Principia/Principes (1644/1647). De no- 
4.2. Referindo-se à prova dita ontológica, A. Sérgio, limita-se a fazer apelo à autoridade da «tão célebre objecção de Kant, na $4 .^{\text {a }}$ secção do capítulo terceiro da Dialéctica transcendental, na Crítica da Razão pura» (p. 135) $\left({ }^{227}\right)$.

4.3. Por fim, notaremos que após ter levantado a questão da influência da época sobre o pensamento de Descar-

tar portanto, que a recusa do intuicionismo de Descartes aparece como infundada.

Antes de se pronunciar sobre a legitimidade e a ilegitimidade das conclusões, A. Sérgio, teria pelo menos de perspectivar os seguintes enunciados: 1) «Ita unvsquisque animo potest intueri, se existere, se cogitari....» (Regulae III, A.T. X.369, cuja tradução Marion é a seguinte: "Ainsi chacun peut regarder par l'esprit, qu'il existe, qu'il pense....» Marion, p. 8); 2) «Et remarquant que cette vérité: je pense donc je suis, était si ferme et si assurée....", Discours, A.T. VL32; 3) «Adeo ut, omnibus satis superque pensitatis deninque statuendum sit hoc pronuntiatum, Ego sum, ego existo, quoties a me profetur, vel mente concipitur, necessario esse verum" (Meditationes, A.T.VII.25); 4) «Enfin il faut conclure et tenir pour constant, que cette proposition, Je suis, j'existe, est nécessairement vraie toutes les fois que je la prononce ou que je la conçois en mon esprit»" (Méditations, A.T.IX.19); 5) «Ac proinde haec cognitio, ego cbgito, ego sum, est omnium prima et certissima, quoae cuilibet ordine philoscphanti occurrat» (Principia, A.T.IX.7); 6) «nous ne saurions nous empêcher de croire que cette conclusion: Je pense, donc je suis, ne soit vraie, et par conséquent la première et la plus certaine qui se présente à celui qui conduit ses pensées par ordre» (Principes, A.T.IX.B.27).

Se nos restringirmos à consideração das polémicas que obrigaram Descartes a recusar a assimilação do cogito das Meditationes/Méditations a um silogismo, temos: resposta à primeira objecção: A.T.VII. 115-116, A.T.IX.91-92; resposta à segunda objecção: A.T.VII.127-128; 140-141; 149-152 e 166; A.T.IX.100-101; 110-111; 117; 129; terceira objecção: A.T.VII.173; A.T.IX.134; resposta à terceira objecção: A.T. VII.174; 178-179; A.T.IX.136 e 139; quarta objecção: A.T.VII.199-200; A.T.IX.155-156; resposta à quarta objecção: A.T.VII.229; A.T.IX.174; resposta à quinta objecção: A.T.VII.352; Alq. II. 792-793; Carta a Clerselier (a propósito das Instances de Gassendi): A.T.IX.205-206; respospostas às sextas objecções: A.T.VII.422; Alq. II. 861-862; respostas às sétimas objecções: A.T.VII.507-508; 522-526; 543-544; Alq. II. 1012-1014; 1030; 1054. (Esta enumeração está longe de ser completa).

Para uma perspectivação histórica do cogito, são indispensáveis as seguintes obras: Léon Blanché, Les antécédents historiques du: je pense donc je suis. Paris, Alcan, 1920; Etienne Gilson, Études sur le rôle de la pensée médiévale dans la formation du système cartésien, Strasbourg, 1921, (hoje consideravelmente aumentado, Paris, J. Vrin, 1930 e 1951). Posteriormente a 1930, notamos: Geneviève Lewis, Augustinisme et cartésianisme à Port-Royal, Paris, P.U.F., 1950; e Henri Gouhier, Augustinisme et cartésianisme au XVII ${ }^{e}$ siècle, Paris, J. Vrin, 1978.

${ }^{(22 T)}$ Mais do que as quatro linhas e meia da alusão que A. Sérgio faz à "Correcção» kantiana do «argumento» de Descartes, tal problemática exige uma obra que produza confrontações textuais e con- 
tes $\left({ }^{228}\right)$, assim como a questão da sinceridade da carta dirigida aos teólogos da Sorbonne ${ }^{(29)}$, A. Sérgio faz a seguinte

textuais. Na viva expectativa de vermos publicadas as Cartas de J. de Carvalho a $A$. Sérgio, cartas que seriam fundamentais para decidir dos limites da breve alusão que $A$. Sérgio faz a Kant, apenas podemos notar que desde a carta em que A. Sérgio anuncia ter começado a tradução Meditações ele nota: «Parece-me que seria muito interessante dar em apêndice uns trechos da Crítica da razão pura que corrigem o nosso Descartes, sobretudo no que respeita ao $E u$ do Cogito e às provas da existência de Deus») (22.III.1930). Esta passagem da carta de A. Sérgio sugere-nos duas questões: a) uma relativa aos condicionamentos do tradutor, questão já levantada em relação à anotação e da qual esta só é um prolongamento (cf. nota 184); b) e, uma relativa à Correcção que Kant possa ter feito relativamente aos pontos alegados por A. Sérgio. Tanto relativamente a uma como a outra destas questões, a Correspondência, fornece-nos elementos imprescindíveis. Assim, temos, relativamente ao condicionamento do tradutor por parte do responsável da edição: «Rogo me diga se acha preferível não dar em apêndice às meditações os trechos do Kant sobre a prova ontológica e sobre o Ego») (2.IV.1930); em relação à questão da correcção, pensamos que ela deveria ser lateralizada por explicitações de noções fundamentais de história da filosofia e de filosofia da história, noções essas de que A. Sérgio nos privou. Entre essas noções/categorias, somos levados a privilegiar a de progresso. $A$ aproximação da significação de uma tal categoria, relativamente à sua aplicação na história da filosofia, é-nos dada pela seguinte passagem da Correspondência: «Eu creio que no seu caso não editaria o Locke, nem o S. Tomás. Para mim, tem havido progresso em filosofia, e o Locke e o S. Tomás parecem-me peças de museu, obsoletas. Daria Platão, Descartes, Espinoza, Malebranche, Kant, Fichte, Hegel, e alguns recentes» (23.1.1932).

$\left({ }^{228}\right)$ A questão que A. Sérgio coloca é a seguinte: «qual teria sido o pensamento explícito de Descartes, se não houvessem influído no seu espírito as ideias teológicas do mundo ambiente e a terribilidade dos poderes que lhe davam apoio» (p. 135). (Interessante tema, que nos transporta além do Absolutamente outro de Emmanuel Levinas e do E.T. de Spielberg, pois tanto o A.O. se fez Mesmo - porque uma vítima era necessária, e isso segundo os antropólogos e os historiadores das religiões -, como o E.T., está transido de traços mítico-sócio-ético-religiosos de carga antropóide. Toda a dificuldade, e é nesse ponto que reside o interesse «do problema intrincado, imaginário talvez, mas muito interessante» (p. 135), que A. Sérgio coloca, reside no pensar do outro, acrónico e atópico. Donde a nossa visível dificuldade em compreender o problema colocado).

$\left.C^{20}\right)$ Relativamente a esta peça, a posição de A. Sérgio não deixa muitas dúvidas. Ela está limpidamente expressa nas seguintes passagens da Correspondência: «Creio inútil traduzir a carta preliminar a Messieurs des Doyens.... Que decide?» (22.III.1930); «Vou pois pôr em romance a virtuosa Epístola, a qual, qualquer que fosse o cheiro de santidade do nosso homem (o que me abstenho de estimar) me parece uma grandessíssima gajice do Papá Descartes. Aqueles salamaleques fazem-me rir, e sinto-me numa farsa de Molière. Malevalência minha, sem dúvida alguma: mas... Comprarei uma pena de pato, que de outra forma não sei dirigir-me Sapientissimis clarissimisque viris....» (2.IV.1930). 
precisão: «Note-se que dizendo isto, não aludimos de maneira alguma ao possível catolicismo de Descartes (se bem que, também nesse ponto haja uma importante colecção de factos que nos inclinam a duvidar) mas só a atitude do nosso filósofo perante os teólogos a quem se dirige» $\left(\right.$ p. 136) $\left({ }^{230}\right)$.

As alusões feitas neste estudo quer às circunstâncias históricas quer às determinações internas ao pensamento de Descartes nos momentos das edições das Meditationes assim como da sua versão francesa, (I. 1.1 a 1.4.11), tinham como função reavivar a complexidade que enquadrou tais acontecimentos. Mais precisamente, pretendemos com tais indicações restituir o contexto de edição do texto que nos ocupa. Apontamos portanto, para o lugar vivo, onde na interacção de disposições diversas, - internas e externas —, a Obra se constitui.

$\mathbf{i}^{230}$ ) «Quanto à minha nota, conclui pela conveniência de acrescentar algumas linhas que esclareçam o meu intuito, o qual não foi ali o de pôr em dúvida a sinceridade do catolicismo de Descartes (se bem que também tenha razoes para não acreditar nela) mas a sinceridade da atitude que ele tomou perante os teólogos da Sorbonne na carta liminar pretendendo arrancar-lhes uma aprovação que ele sabia imerecidíssima. Tenho pois duas teses: ....», segue-se a exposição dessas teses. Dessa argumentação destacamos apenas um ponto: « $2 .^{\circ}$ ponto. $O$ catolicismo do papá Descartes. Não li o livro do Gouhier (trata-se de La pensée religieuse de Descartes, 1924), nunca o vi, nem sei que método adoptou. Se foi o da análise dos textos, começarei por declarar que, neste caso, o acho contestável, porque exactamente o que se discute é a sinceridade desses textos. Por isso, apego-me aos factos». Após expor todos os seus argumentos, A. Sérgio conclui: "O passo duvidoso da nota poderia ficar assim um poucochinho acrescentado: «Essa sinceridade é, em nosso juízo, simplesmente nula. | Note-se que dizendo isto não aludimos de maneira nenhuma ao possível catolicismo de Descartes (se bem que, também nesse ponto, haja uma importante colecção de factos que levam a dúvida ao nosso espírito) mas só à atitude do filósofo perante os teólogos a que se dirige. ! Não cabem aqui....», e A. Sérgio precisa: «Indiquei por traços verticais o período que proponho acrescentar» (1.XII.1930). Uma última carta onde o mesmo assunto é tratado, produz uma última correcção: «Recambio, inclusa, a prova da nota. Em lugar de dizer que a sinceridade do papá Descartes me parece simplesmente nula, passo a afirmar que se me afigura bem contestável. Fica menos dogmático, menos forte» (12.XII. 1930).

Uma leitura da obra de $H$. Gouhier, permite uma melhor ressituação da argumentação de A. Sérgio: Henri Gouhier, La pensée religieuse de Descartes, Paris, J. Vrin, 1924. 
Pretendemos igualmente seguir, - de um modo particularmente cursivo-, as linhas gerais que podem caracterizar as mais importantes edições desta obra desde a morte do seu autor a 1976. Da perspectivação deste longo período resultam aspectos que em visível contraste com os diferentes momentos de aparição do texto, são susceptíveis de nos revelar diferentes atitudes, tendências culturais, relativas à recepção e à transmissão da obra.

Assim, num primeiro tempo, e certamente, seguindo a proposta de dessiminação patrocinada por de Luynes e Clerselier, e apoiada por Descartes, - proposta essa que consistiu na tradução das Meditationes em língua vulgar e que culminou com a edição de 1647 -, podemos constatar que anteriormente à edição A.T., os diferentes editores tomam como referente das suas edições a versão francesa da obra. Com efeito, só depois da edição A.T., a especificidade dos textos latino e francês, aparece como um facto estabelecido. A reivindicação e o reconhecimento de tal especificidade só é compreensível quando ressituada na convergência das histórias da paleografia, da filologia e da hermenêutica. A sua incidência ao nível da história da filosofia e da filosofia da história, níveis de que ela é indissociável, tem a mais ampla das repercussões. Reconhecer tal especificidade significa, antes de mais, tornar-se atento ao pensamento tal como ele (se) vive: em via(s) de desenvolvimento(s). O mesmo é dizer que tal implica entrar em linha de conta com a instabilidade, a flutuação, as diferenças presentes nas variações textuais. São tais propostas, onde a história da filosofia aparece intimamente conexa com uma filosofia da história particularmente atenta à diferença, que determinam as diferentes edições bilingues feitas depois da edição A.T. Todavia, um tal acordo, está longe de constituir uma proposta homogénea: nem sempre os editores encontraram um consenso relativamente aos textos de referência. Como nos podemos aperceber, se G. Rodis-Lewis considera o texto publicado por A.T. como texto de referência, isso não significa que ela reproduz a edição A.T., pois a editora, ao assinalar todas as divergências existentes entre os textos latino e francês, afasta-se da edição de referência. Algo de mais complexo acontece ainda relativamente ao restabelecimento que F. Alquié faz do texto das Meditationes (1.6.2 a I. 6.2.2).

Quanto às edições do texto das Méditations, texto que, como já notamos, serviu de referente a vários editores até ao momento em que A.T. reivindicou a especificidade, a diferença, dos textos latino e francês, notaremos que, o texto que designamos no diagrama de génese, (Diagrama II), por 
G2, texto de segunda geração, resulta de uma intervenção livre de Clerselier relativamente ao original francês, Gí, (1.5.1). Uma tal parasitagem «naïve», assim como a que R. Fédé lhe acrescenta, - definindo assim um texto de terceira geração constitui um índice significativo das atitudes dos editores do séc. XVII, face às obras que editam.

Tal atitude é reiterada, durante a primeira metade do séc. XIX, pelas reproduções que V. Cousin, (I. 5.2), e Garnier fazem dos textos de Clerselier e de Fédé. Relativamente a tais disposições, a edição A.T., ao defender o retorno ao original de 1647 , propõe uma viragem determinada por marcadas motivações paleográfico-filológicas. Tais características definem as linhas gerais de uma quarta geração de textos, G4, textos que reivindicam uma aproximação em relação a Gl (I. 5.3.2).

Porque a nossa pretensão foi de melhor situar a edição portuguesa das Meditações em relação à sua época, e porque, tudo nos leva a pensar uma época como o «lugar dilatado» da intercepção de um passado e de um futuro, e porque a importância de uma edição reside nos critérios que ela activa e nas perspectivas de investigação que ela veicula, fomos conduzidos a apresentar as tendências mais marcantes das edições das Méditations, posteriores a 1930, data da tradução portuguesa.

Tal investigação levou-nos a definir um conjunto de três novas gerações de textos. A quinta, G5 e a sexta, G6, definida pelos textos bilingues publicados por G. Rodis-Lewis, (1.6.1), e por F. Alquié, (1.6.2.3). Além do facto de ser bilingue, a edição de G. Rodis-Lewis, tem como principais características, retomar e transformar o texto da edição A.T., e isso, de modo a assinalar as divergências existentes entre os textos latino e francês. Como elementos subsidiários, - elementos de importância capital - essa edição utiliza o texto de Clerselier, G2, e produz uma importante anotação de carácter paleográfico, histórico e conceptual. Por seu lado, a edição F. Alquié do texto francês, directamente inspirado da edição de 1647, produz, além de uma restituição do francês de Descartes em francês actual, algumas modificações relativamente à ortografia da edição de 1647. Servindo-se da edição de G. Rodis-Lewis, G5, assim como da edição Clerselier, G2, para anotar e completar a edição de 1647, G1, F. Alquié, consagra as tendências reveladas pela edição de G. Rodis-Lewis, produzindo uma importante anotação paleo-histórico-conceptual.

A última geração de textos que destacámos, é a septima, G7, a de A. Robinet: Cogito 75, (1.6.3 a I. 6.3.5). Retomando a quasi-totalidade das transformações ortográficas de G6, esta 


\section{Antonio Sérgio}

edição reata com o texto original, $G 1$, e portanto segue, em certos aspectos G4. Como características fundamentais dessa edição, notamos a supressão de anotações, facto correlativo de uma exaustiva "anotação do autor por ele mesmo», constituída pela ordenação e quantificação do léxico que assim transformado aparece como um conjunto de factos reveladores das mais íntimas relações que se estabelecem entre pensamento e linguagem.

Foram os dados lexicais fornecidos por esta última edição que nos serviram de apoio para a elaboração de uma grande parte do segundo aspecto da nossa investigação: a análise da restituição que a tradução portuguesa faz das formas raison, raisons e nature, (II. 4.1 a II. 5.7). Tal análise, revelou-nos múltiplas distorções, omissões, adições e vicariâncias.

$\mathrm{Na}$ última parte do estudo, procedemos a um levantamento das preocupações mais marcantes que o tradutor exprimiu na sua Nota terminal à tradução (III. 1 a III. 4.3). A leitura da Correspondência com J. de Carvalho, mostrou-nos que tais preocupações eram subjacentes a toda a actividade de tradutor/editor desenvolvida por A. Sérgio entre os anos de 1927 a 1932-1933. Tal exame conduziu-nos a pensar que a expressão que tais preocupações encontram na Nota terminal. é não só deficiente como insuficiente.

Em tais circunstâncias, como situar relativamente às edições anteriores e posteriores a 1930 esta tradução de A. Sérgio?

Se a nota 32 da tradução dos Novos Ensaios de Leibniz, edição publicada um ano depois da tradução das Meditações, nos faz saber que a tradução de A. Sérgio tem como referente a edição A.T., nada nessa tradução confirma uma tal referência. Mais precisamente, A. Sérgio, ao servir-se da edição A.T. das Meditationes, (t. VII), e das Méditations, (t. IX), não toma em consideração, nem a especificidade desses dois textos, nem a especificidade dessa edição. O mesmo é dizer que A. Sérgio reproduz em relação a uma edição que justamente ele qualifica como «a melhor», as atitudes que Clerselier, Fédé, Cousin e Gamier tiveram relativamente ao texto de 1647. Assim, A. Sérgio utiliza na sua tradução um referente de quarta geração, e reitera critérios de parasitagem "naïves», características das edições do séc. XVII, mais precisamente, das segundas e terceiras gerações. Se considerarmos a atitude de A. Sérgio relativamente ao paradigma "A.T.», estamos confrontados a uma situação de reprodução idêntica àquela que caracterizou as edições Fédé, Cousin e Clerselier. 
Este último aspecto, apresenta-nos pois um A. Sérgio confiante num «melhor» pré-estabelecido.

Os aspectos correlativos destas duas últimas caractérisa ticas são a distorção do original e a falta de perspectivas inovadoras que a tradução de A. Sérgio veicula. 